\title{
Journal of the Geological Survey of Brazil
}

\section{The Troia-Pedra Branca mafic-ultramafic complex, Borborema Province, Brazil: Record of 2.04 Ga post-collisional Alaskan-type magmatism and PGE mineralization}

\author{
Felipe Grandjean da Costa ${ }^{1 *}$, Wagner da Silva Amaral ${ }^{2}$, ${ }^{(1)}$, Hector Rolando Barrueto ${ }^{3}$, \\ João Luiz Carneiro Naleto ${ }^{(\mathbb{D}}$, Joseneusa Brilhante Rodrigues ${ }^{5(\mathbb{D}}$, laponira Paiva Gomes ${ }^{1}$ \\ ${ }^{1}$ Geological Survey of Brazil, Fortaleza, Av. Antônio Sales, 1418, Bairro Joaquim Távora, Fortaleza, CE, Brazil, CEP: 60135-101 \\ ${ }^{2}$ Department of Geology and Mineral Resources, Institute of Geosciences, State University of Campinas - UNICAMP, \\ R. Carlos Gomes, 250, Campinas, SP, Brazil, CEP: 13083-885 \\ ${ }^{3}$ Codelco do Brasil Mineração Ltda., Praia do Botafogo, 228, $10^{\circ}$ Andar, Sala 1003, Rio de Janeiro, RJ, Brazil, CEP: 22250-606 \\ ${ }^{4}$ Geological Survey of Brazil, R. Costa, 55, Bairro Cerqueira Cesar, São Paulo, SP, Brazil, CEP: 01304-010 \\ ${ }^{5}$ Geological Survey of Brazil, SBN, Quadra 02, Bloco H, $2^{\circ}$ Andar, Brasília, DF, Brazil, CEP: 70040-904
}

\section{Abstract}

The Troia-Pedra Branca complex is the most extensive exposure of mafic-ultramafic rocks in the Borborema Province, northeastern Brazil. These rocks have been known for a long time, particularly because of their platinum group element (PGE) mineralization associated with chromitites. The Troia-Pedra Branca complex consists of a succession of serpentinites (after dunite), metachromitites, metaperidotites, hornblendites and metagabbros. PGE-bearing metachromitites are hosted by the serpentinite-peridotite unit, occurring as dispersed blocks, well preserved from weathering. However, host metadunites are poorly preserved, and are only accessed by drill core samples. Scanning Electron Microscopy (SEM) analysis in thin sections of selected metachromitite samples revealed that most of the platinum group minerals (PGM) occur in the chlorite-serpentine matrix, generally in contact with chromite grains. The main PGM are sperrylite $\left(\mathrm{PtAs}_{2}\right)$, cooperite (PtS), irarsite ((Ir,Pt,Rh)AsS) and hollingworthite $((\mathrm{Rh}, \mathrm{Pd}, \mathrm{Pt}, \mathrm{Ru}) \mathrm{AsS})$. Within chromite grains, very few PGM were found, and sulfide inclusions are mainly chalcopyrite $\left(\mathrm{CuFeS}_{2}\right)$, pentlandite $\left((\mathrm{Fe}, \mathrm{Ni})_{9} \mathrm{~S}_{8}\right)$ and bornite $\left(\mathrm{Cu}_{5} \mathrm{FeS}_{4}\right)$. Whole-rock geochemical data reveal that metagabbros are LILE-enriched and show subduction-related signature similar to that of Alaskan-type intrusions. Mineral chemistry of chromite and olivine is also compatible with arc-related Alaskan-type complexes. The U-Pb SHRIMP zircon age for a metachromitite sample yielded an upper intercept age of $2036 \pm 27 \mathrm{Ma}$, which we interpret as the crystallization age. However, dispersion in the data implies that zircons lost variable amounts of radiogenic $\mathrm{Pb}$ at around $749 \pm 54 \mathrm{Ma}$ (lower intercept), which may be related to Neoproterozoic metamorphism. The age obtained for the Troia-Pedra Branca metachromitites (2036 Ma) is younger than the $2190-2130 \mathrm{Ma}$ arc-related plutons of the area, and it is closely related in age to the $2.10-2.04 \mathrm{Ga}$ syn- to late-collisional plutonism and high-temperature metamorphism. Therefore, this Alaskan-type mafic-ultramafic magmatism may be related to the postcollisional setting of the 2.2-2.0 Ga Eburnean/Transamazonian orogeny.
Article Information

Publication type: Research papers

Received 28 May 2021

Accepted 17 July 2021

Online pub. 31 August 2021

Editor: Carlos Spier

Keywords:

Troia-Pedra Branca

Mafic-ultramafic

Platinum

Chromite

Alaskan-type

${ }^{*}$ Corresponding author

Felipe Grandjean da Costa

felipe.costa@cprm.gov.br

\section{Introduction}

Mafic-ultramafic rocks, including chromitites, and associated platinum group element (PGE) mineralization may form as part of oceanic crust (ophiolite), along arc-related magmatism (Alaskan-type complex) or in continental (non-orogenic) layered intrusions (e.g., Bushveld complex) (e.g., Naldrett and Cabri 1976, Naldrett 2004, Ripley et al. 2005, Barnes and Lightfoot 2005, Naldrett et al. 2012, Barnes and Ripley 2016).
Alaskan- or Uralian-type mafic-ultramafic intrusions (Taylor 1967, Irvine 1974, Himmelberg and Loney 1995, Batanova et al. 2005) are often reported in the literature as hosting PGE mineralization (e.g., Johan et al. 1989, Garuti et al. 2002, 2003, Ishiwatari and Ichiyama 2004, Ripley et al. 2005, Kutyrev et al. 2021). Alaskan-type complexes are generally interpreted as arc-related magmatism, which is in agreement with the tectonic environment of their original study area (North American Cordillera, e.g., Himmelberg and Loney 1995). In 
short, the term Alaskan-type (or Uralian-Alaskan-type) may be used to classify mafic-ultramafic complexes worldwide, from Archean to Phanerozoic times, with similar rock associations (e.g., dunites, hornblendites, chromitites, pyroxenites, gabbros and diorites), arc-related geochemical signature and PGE mineralization (e.g. Johan et al. 1989, Garuti et al. 2002, 2003, Helmy and El Mahallawi 2003, Pettigrew and Hattori 2006, Farahat and Helmy 2006, Eyuboglu et al. 2010, Krause et al. 2011, Tseng et al. 2015, Yuan et al. 2017, Han et al. 2018, Abdallah et al. 2019, Yellappa 2021, Kutyrev et al. 2021).

Similar types of mafic-ultramafic intrusions are found within the Archean to Paleoproterozoic basement rocks of the Troia Massif, in northern Borborema Province, Brazil (Fig. 1). The Troia-Pedra Branca complex consists of the most extensive occurrence of mafic-ultramafic rocks in this province, and their chromitite occurrences have been known for more than thirty years, particularly because of their PGE mineralization (e.g., Gomes et al. 1981, Simões 1993, Angeli et al. 1993, Angeli 2005, Angeli et al. 2009, Barrueto and Hunt 2010). It consists of variably metamorphosed dunite-peridotites, chromitites, hornblende gabbros and minor gabbro-diorites. However, there are limited geochemical and geochronological data in the literature for this mafic-ultramafic complex, and no detailed characterization of the PGE mineralization has been published to date. Therefore, a better understanding of the petrogenesis of this mafic-ultramafic magmatism is still needed, particularly to constrain the genetic model of its PGE mineralization. In this manuscript, we provide field and petrographic observations, whole-rock and mineral geochemistry, and $\mathrm{U}-\mathrm{Pb}$ (SHRIMP) zircon data for these mafic-ultramafic rocks. These new data provide information on the magma chemistry/source, characteristics of the PGE mineralization, and the tectonic setting of the Troia-Pedra Branca mafic-ultramafic complex, aiming to broaden the knowledge about PGE mineralization and its hosted rocks.

\section{Geological setting}

\subsection{Archean-Paleoproterozoic basement of the northern Borborema Province}

The geology of the Borborema Province is complex, comprising several tectono-stratigraphic domains that were structured during the Neoproterozoic, with Archean to Paleoproterozoic basement inliers (Brito Neves 1975, Almeida et al. 1981). This province comprises an area of ca. 450,000 $\mathrm{km}^{2}$ in northeastern Brazil, and its final configuration resulted from the convergence of the Amazon, São Luis/West African and São Francisco/Congo cratons during the Brasiliano/Pan African orogeny (Brito Neves and Cordani 1991, Trompette 1994) (Fig. 1 A). The Borborema Province is divided into the Southern and Transversal zones, and the northern Borborema Province (Fig. 1 B). The northern domain hosts three of the most important Archean to Paleoproterozoic Basement inliers of this Province: (i) the São José do Campestre Domain, (ii) the Granjeiro Complex and (iii) the Troia Massif (Fig. 1 B).

The Troia Massif dominantly encompasses Neoarchean TTG gneisses (Troia Massif/Cruzeta complex of 2.8-2.7 Ga) (Brito Neves 1975, Fetter 1999, Ganade de Araújo et al. 2017) which are enveloped by Paleoproterozoic (Rhyacian) gneisses, migmatites and metavolcano-sedimentary sequences, with ages ranging from 2.17 to $2.03 \mathrm{Ga}$ (Fetter et al. 2000, Martins et al. 2009, Silva et al. 2014, Costa et al. 2015, 2018). These Archean to Paleoproterozoic rocks are the basement for Neoproterozoic supracrustal volcano-sedimentary rocks represented by the Ceará Complex and the Novo Oriente Group (Arthaud et al. 2008, Ganade de Araújo et al. 2010, 2012, Garcia et al. 2014). In general, all these units (basement and supracrustal rocks) were strongly deformed and migmatized during the Brasiliano/ Pan African orogeny (e.g., Castro 2004, Arthaud et al. 2008). The structural patterns found in Troia Massif are dominated by early low-angle foliation related to nappe tectonics (Caby and Arthaud 1986) that probably occurred at 650-610 Ma. This was followed by the late development of large NNE-SSW transcurrent shear zones at $\sim 590-530 \mathrm{Ma}$ (e.g., Vauchez et al. 1995, Monié et al. 1997). The high-grade metamorphism in the surrounding basement rocks is locally found, represented by high-pressure granulite facies ( 650-640 Ma) (Castro 2004, Amaral 2010, Amaral et al. 2012), with some relict of ultra-high pressure rocks (Santos et al. 2015), and subsequent regional high-temperature granulite/amphibolite metamorphism (630$610 \mathrm{Ma}$ ) (Arthaud 2008, Amaral 2010, Amaral et al. 2012).

\subsection{The Troia-Pedra Branca mafic-ultramafic complex}

The mafic to ultramafic rocks of the Troia Massif have been collectively termed as the Troia unit (Oliveira and Cavalcante et al. 1993) or the Pedra Branca mafic-ultramafic complex (Fleet et al. 1993, Angeli et al. 1993). They occur in the central part of the Troia Massif and are the most expressive occurrence of mafic to ultramafic rocks in the Borborema Province (Fig. $1 \mathrm{C})$. The occurrence of chromitites in this region have been recognized since the 1980s because of their associated PGE mineralization (Gomes et al. 1981, Simões 1993, Angeli et al. 1993). The Troia-Pedra Branca mafic-ultramafic complex consists of a succession of serpentinites (after dunite), metaperidotites (after clinopiroxenite), hornblendites, hornblende metagabbros and metagabbro-diorites (e.g., Angeli 2005, Barrueto and Hunt 2010, Lomas et al. 2019). The PGE-bearing metachromitites are hosted by the metadunites, which consist of metamorphosed coarse- to medium-grained olivine-websterite cumulates (e.g., Angeli 2005, Barrueto and Hunt 2010, Lomas et al. 2019). The ultramafic units were metamorphosed to greenschist to lower amphibolite facies and comprise chlorite schist, talc-tremolite-actinolite schist, talc-serpentine schist, serpentinite and anthophyllite schist (e.g., Pessoa and Archanjo 1984, Pessoa et al. 1986).

The rocks of the Troia-Pedra Branca complex are highly deformed. The main folds and foliation probably developed during thrusting, synchronously with the intrusion of the syntectonic S-type Cedro granites (Fig. 1 C) at ca. $2100 \mathrm{Ma}$ (Pessoa and Archanjo 1984, Pessoa et al. 1986). However, ca. $600 \mathrm{Ma}$ Neoproterozoic deformation and metamorphism also occur in the area (Brito Neves 1975, Pessoa et al. 1986, Fetter 1999, Costa et al. 2019).

The metachromitites from the Troia-Pedra Branca complex occur as lenses in metadunite-metaperidotite, and are up to $30 \mathrm{~m}$ long, $1.4 \mathrm{~m}$ wide and $1 \mathrm{~m}$ thick (e.g., Angeli 2005, Barrueto and Hunt 2010). The PGE-bearing metachromitites comprise five known deposits (Curiu, Esbarro, Cedro, Trapia and Santo Amaro, Fig. $1 \mathrm{C}$ ), which host altogether a measured resource of $17.9 \mathrm{Mt}$ at $0.77 \mathrm{~g} / \mathrm{t} \mathrm{Pd}, 0.45 \mathrm{~g} / \mathrm{t} \mathrm{Pt}$ and $0.04 \mathrm{~g} / \mathrm{t}$ $\mathrm{Au}$ (Lomas et al. 2019). The mineralized metachromitites crop out at surface, and all of the inferred resources are potentially open pit mineable (Lomas et al. 2019). 

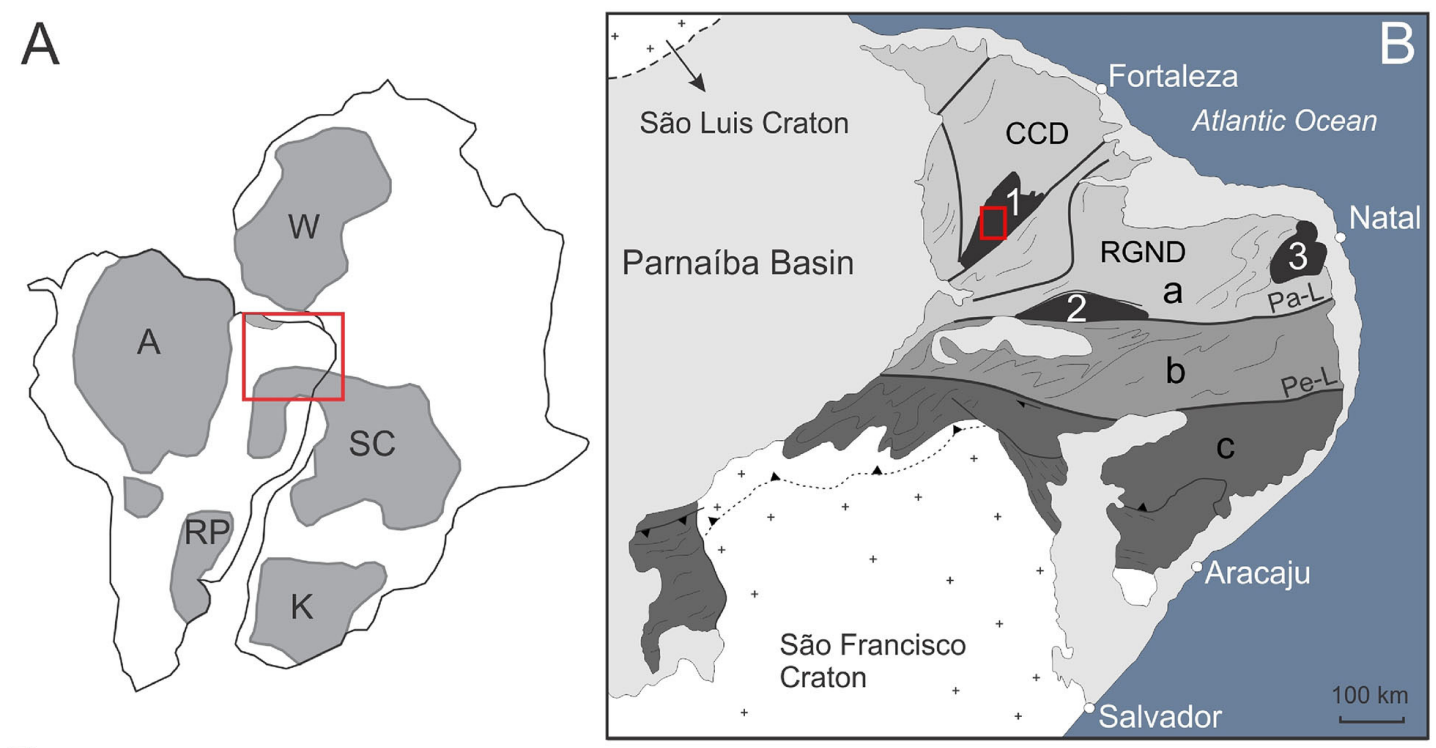

C

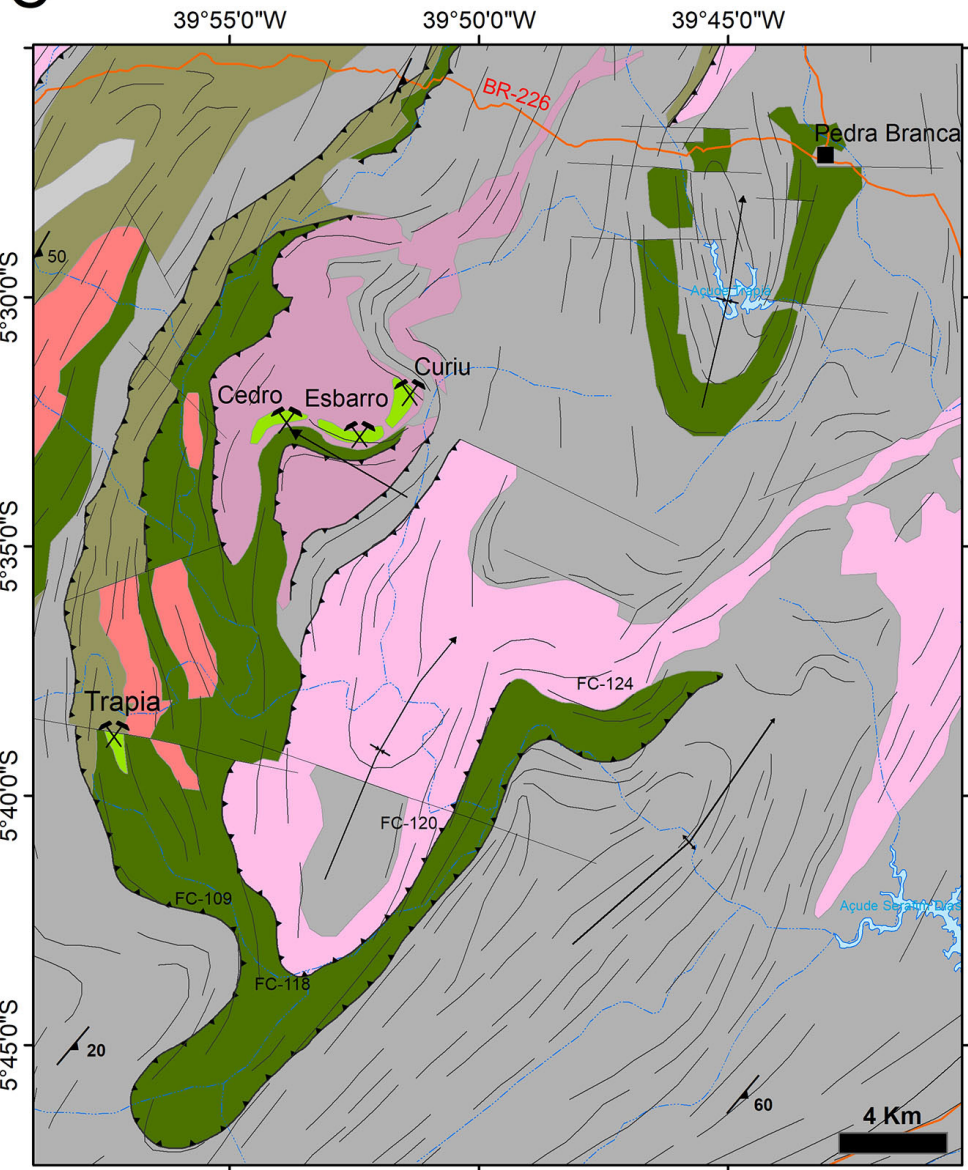

Legend

$$
\begin{aligned}
& \sim \text { Foliation trend } \\
& \text { Fault and/or shear zone } \\
& \text { _.. Transpressional shear zone } \\
& \text { - Foliation } \\
& \longrightarrow \text { Antiform with indicated dip } \\
& \longrightarrow \text { Synform with indicated dip }
\end{aligned}
$$

Paleoproterozoic (2.2 - 2.0 Ga)

S-type granite - Cedro Suite

Granitic orthogneisses - Bananeira

Metavolcano-sedimentary rocks

Metaultramafic rocks

Mafic-ultramafic rocks - Troia Unit Metatonalites

\section{Archean (2.7-2.8 Ga)}

TTG gneisses - Cruzeta complex

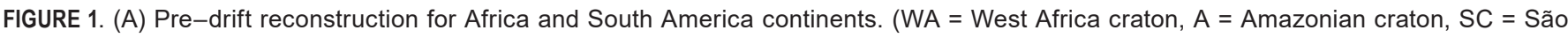
Francisco - Congo craton, $\mathrm{RP}=$ Rio de la Plata craton, $\mathrm{K}=$ Kalahari craton). Rectangle outlines approximate the area of Fig. $1 \mathrm{~B}$. (B) Schematic structural map of NE Brazil (modified from Trompette 1994) showing the three major subdivisions of the Borborema Province delimited by the Patos Lineament (Pa-L) and the Pernambuco Lineament (Pe-L), (a)- Northern Borborema Province, (b)- Transversal zone and (c)- Southern frontal zone. At the northern Borborema Province, the three major Archaean blocks are highlighted (1)- Troia Massif or Cruzeta Complex, (2)- Granjeiro Complex and (3)- São Jose do Campestre Massif. CCD = Ceará Central Domain and RGND = Rio Grande do Norte Domain. Rectangle outlines approximate the area of Fig. 1 C. (C) Geological map of the Paleoproterozoic Troia-Pedra Branca mafic-ultramafic complex and surrounding Archean TTG gneisses of the Troia Massif (modified after Oliveira and Cavalcante 1993). The Santo Amaro deposit is not shown in Fig. $1 \mathrm{C}$, as it occurs outside of the area, further north in the Troia Massif. 


\section{Materials and methods}

\subsection{Whole-rock geochemistry}

Major and trace elements analyses of whole-rock were carried out respectively by $\mathrm{X}$-ray fluorescence (XRF) and inductively coupled plasma-mass spectrometry (ICPMS) at the SGS GEOSOL laboratory in Vespasiano, Minas Gerais (Brazil), following the XRF79C and IMS95A analytical methods. For major element analyses, the rock powders $(2 \mathrm{~g}$ per sample) were dried in an oven and weighed after cooling in a jar containing lithium tetraborate flux. The samples were then transferred to a platinum crucible and homogenized. After homogenization, lithium iodide was added before fusion and analysed by XRF. For trace element analyses, the rock powders (10 g per sample) were weighed separately and then fused in a graphite crucible by adding lithium metaborate. After fusion, the melt was transferred to a beaker containing a solution of nitric acid and tartaric acid in equal volumes for homogenization and total dissolution under agitation, and analysed by ICP-MS. The analytical accuracy was monitored using geological standard materials, TILL-03 and GRE-03 for trace elements on ICP-MS, and SG-142 and AMIS0321 for major elements on XRF. Analytical precision for major elements is better than $5 \%$ and better than $10 \%$ for trace elements analyses and the blank material yielded values below the detection limits. The results are shown in Table 1. The geochemical analyses were plotted using the GCDkit software (Janousek et al. 2006).

\subsection{Major element mineral chemistry}

Quantitative mineral analyses were carried out using a Zeiss Sigma HD Field Emission Gun Analytical Scanning Electron Microscope (ASEM) equipped with two Oxford Instruments $150 \mathrm{~mm}^{2}$ EDS detectors, at Cardiff University. Operating conditions were set to $20 \mathrm{kV}$, with analytical drift checked periodically every 20 minutes using a Co reference standard. Suites of standards from ASTIMIX and Smithsonian were used to calibrate the EDS analysis and perform regular secondary standard checks every hour. The raw data were recalculated to element oxides percentages; $\mathrm{Fe}^{2+}$ and $\mathrm{Fe}^{3+}$ were calculated using Droop's stoichiometric method (Droop 1987). Representative analyses can be found in Table 2 for chromite and in Table 3 for olivine.

\subsection{U-Pb SHRIMP zircon age}

Zircon $\mathrm{U}-\mathrm{Pb}$ isotope analyses were made for a metachromitite sample ( $\mathrm{JN}-88)$ using secondary ion mass spectrometry (SIMS) with the SHRIMP lle microprobe (Sensitive High Resolution Ion Microprobe) at the Geochronological Research Centre (CPGeo) at São Paulo University (USP), Brazil. The data were reduced according to the methods in Williams (1998) and Sato et al. (2008). Uncertainties given for individual $\mathrm{U}-\mathrm{Pb}$ analyses are at $1 \sigma$ level. For calculations of age, corrections for common $\mathrm{Pb}$ were made using the measured ${ }^{204} \mathrm{~Pb}$ and the relevant common $\mathrm{Pb}$ compositions from the model by Stacey and Kramers (1975). For details of the method employed for SHRIMP-Ile U-Pb zircon analysis and data processing, refer to Sato et al. (2008, 2014). Concordia plots, regressions and calculations of age were carried out using Isoplot/Ex 4.15 (Ludwig 2003). U-Pb geochronological results are shown in Table 4.

\section{Field geology and petrography}

\subsection{Metagabbros and associated hornblendites}

Regionally, the metagabbros of the Troia-Pedra Branca mafic-ultramafic complex delineate a kilometric folded structure, with fold axis dipping gently to NE (Fig. $1 \mathrm{C}$ ). Metagabbros are the most abundant rocks in this complex, and persistently outcrop in large areas (Fig. 2 A). Most metagabbros are composed essentially of hornblende and plagioclase, commonly showing stretched mineral lineation (Fig. 2 B) and highly foliated domains (Fig. 2 C). Deformation generally masks some primary magmatic textures and aligns hornblende-rich layers with leucocratic plagioclaserich metagabbros (Fig. 2 C). However, in less deformed domains, some mingling textures of the gabbroic magma with aphanitic ultramafic enclave are found locally (Fig. 2 D). In thin sections, the texture of these metagabbros is mainly nematoblastic, formed by the orientation of hornblende and plagioclase crystals (Fig. 2 E). The hornblende crystals are prismatic and tabular, with dark-green to brown-green pleochroism (Fig. 2 E). Plagioclase crystals are xenoblastic, rarely twinned in albite, and commonly occur as stretched crystals, recrystallized in sub-grains. Hornblende is the main mafic mineral present in the metagabbros, but there were also some relicts of clinopyroxene (Fig. 2 F), as well as minor biotite crystals at more evolved gabbro-dioritic facies (Fig. $2 \mathrm{G}$ ). Andesine is the dominant feldspar in the metagabbro, and in more evolved gabbro-dioritic samples, potassium feldspar (microcline) is a minor mineral (Fig. 2 $H$ ). Major accessory minerals are titanite, rutile, apatite and opaque oxide phases.

Outcrops of hornblendites have been recognized in the area (Fig. 3 A, B and C), and they are spatially associated with the metagabbros. The hornblendites crop out as large boulders, showing coarse idiomorphic dark-green hornblende phenocrysts in an interstitial plagioclase matrix (Fig. $3 \mathrm{~A}$ and B). Massive hornblendites (plagioclase-free) are also found to be in contact with porphyritic hornblendites, suggesting primary magmatic layering textures (Fig. $3 \mathrm{C}$ ).

\subsection{Metadunites}

Metadunites have not been recognized in the field, as their mineralogy (dominantly olivine) is highly susceptible to tropical weathering, therefore fresh metadunites can only be accessed by means of drill core samples. These samples generally show cumulate textures comprising coarse (up to 4 cm large) olivine crystals (Fig. 4 A and B) and medium-grained olivine grains (Fig. $4 \mathrm{C}$ ). The relict olivine crystals are partially altered to serpentine (Fig. 4 A and B). Locally, metadunites are completely altered to serpentinite along faults and/or shear bands (Fig. 4 D). In thin section, the olivine and minor chromite crystals are relicts of the main primary minerals within a metamorphic matrix (Fig. $4 \mathrm{E}$ and F). Magnetite is commonly lamellar-textured, occurring between serpentine and surrounding the chromite rims, possibly a by-product of serpentinization of olivine (Fig. 4 E). Serpentine is the main mineral of the metamorphic matrix, but it also occurs as a 

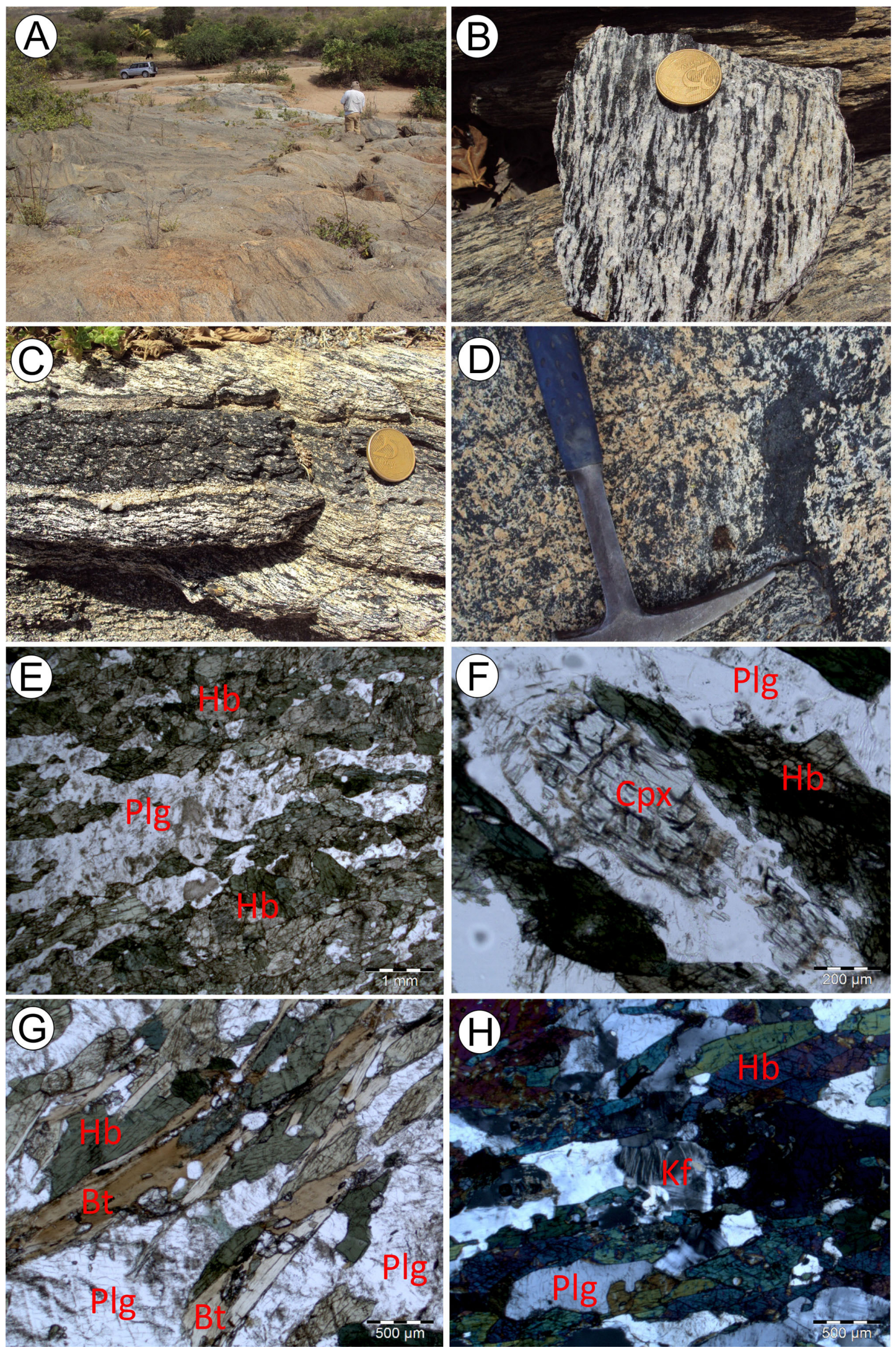

FIGURE 2. (A) Large outcrop of a massive gray colored metagabbro. (B) Hand sample (FC-06A) of a coarse-grained metaleucogabbro with stretched plagioclase (white) and hornblende (black) crystals. (C) Alternating bands of deformed melanogabbro (darker) and leucogabbro (lighter) as compositional layers. Black minerals are hornblende and white minerals are plagioclase. (D) Slightly deformed metagabbro hosting an ultramafic microgranular enclave. The inserted plagioclase phenocrystal within the enclave suggests mingling texture. (E) Photomicrograph in plain polarized light showing a hornblende $(\mathrm{Hb})$-rich (meta)melanogabbro with xenoblastic plagioclase (Plg) matrix (Sample FC-118). (F) Photomicrograph in plain polarized light showing relict clinopyroxene (Cpx) crystal rimmed (replaced) by hornblende (Hb) (sample FC109). (G) Photomicrograph in plain polarized light, showing brown biotite (Bt) intergrowth with green hornblende (Hb) (sample FC-120). (H) Photomicrograph in cross polarized light showing a potassium feldspar (Kf) from a metagabbro-diorite sample (sample FC-109). 

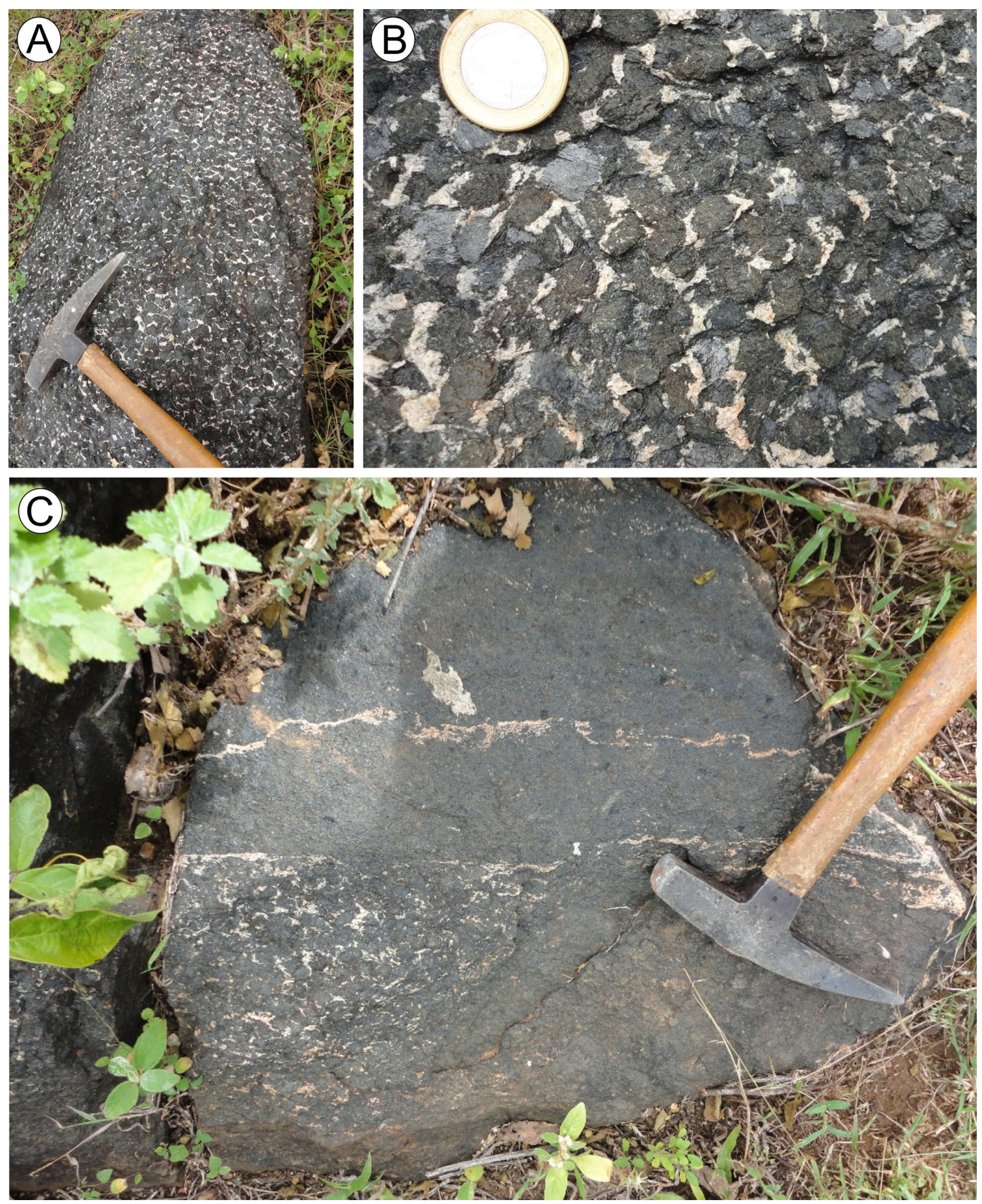

FIGURE 3. (A) Field aspect of a hornblendite boulder mainly composed of hornblende (dark) and plagioclase (white). (B) Close view of coarse idiomorphic dark-green hornblende phenocrystals and interstitial plagioclase matrix. (C) Massive hornblendite (dark layer) in contact with a porphyritic hornblendite with plagioclase matrix.

net-structured framework within olivine, probably reflecting hydrothermally altered micro fissures (Fig. $4 \mathrm{~F}$ and G). Also, serpentine is frequently rimming the olivine crystals (Fig. 4 $A$ and $\mathrm{H})$.

\subsection{Metachromitites and PGE mineralization}

Metachromitites generally occur as dispersed blocks that are 10 to $60 \mathrm{~cm}$ long (Fig. $5 \mathrm{~A}$ ). They are relatively well preserved from weathering. In trench exposures, metachromitites occur as discontinued lenses within weathered metadunites (Fig. 5 B). On a hand-specimen scale, metachromitites are generally homogeneous, containing 30 to $60 \%$ of chromite immersed into gray chlorite- and serpentine-bearing groundmass (Fig. $5 \mathrm{C}$ and D). Crystal size of chromite ranges from 1 to $5 \mathrm{~mm}$, and this mineral shows semi-massive and disseminated-textures (30-80\% chromite), and locally well-banded structures, with alternating coarse- and fine-grained chromitite layers (Fig. 5 C). Silicate-rich seams also occur in chromitites, with ca. $3 \mathrm{~cm}$ width alternating with chlorite-chromitite layers/ bands (Fig. $5 \mathrm{E}$ ). The silicate layers are mainly composed 

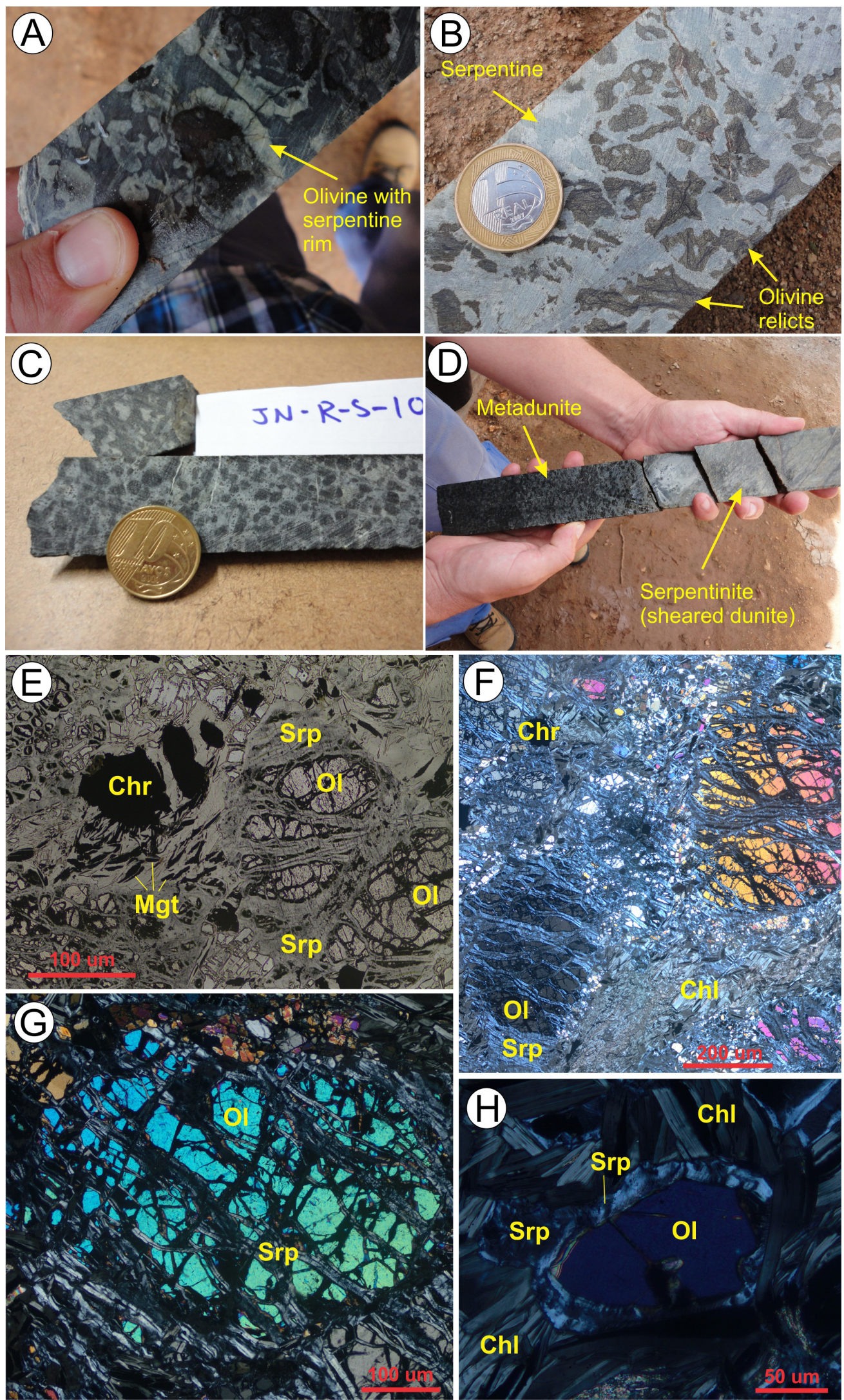

FIGURE 4. (A) Drill core sample of a coarse olivine cumulate rock. Note the serpentinized rims of the large $(\sim 3 \mathrm{~cm})$ olivine crystals. (B) Relicts of large olivine crystals in a serpentinized matrix. (C) Close view for drill core samples of a medium-grained metadunite with preserved olivine crystals (black minerals in the photo) within a gray serpentine matrix. (D) Drill core sample of a medium-grained metadunite altered to serpentinite along a shear band. (E) Photomicrograph in plain polarized light showing chromite (Chr) and olivine (OI) crystals from a metadunite drill core sample. The chromite and olivine are relicts in a metamorphic matrix of serpentine (Srp) and magnetite (Mgt). (F) Photomicrograph with cross polarized light showing sub rounded olivine (OI) crystals surrounded by metamorphic chlorite (Chl) and serpentine (Srp). (G) Photomicrograph with cross polarized light showing a vein-like network of serpentine (Srp) in a relict olivine (OI) crystal. (H) Photomicrograph with cross polarized light showing an olivine (OI) crystal rimmed by serpentine (Srp) in a dominantly chlorite (Chl) matrix. 
of tremolite/actinolite (after clinopyroxene) (Fig. 5 E). Thin sections of chromitite samples reveal subhedral to anhedral chromite grains (Fig. 6 A), and interstitial silicates are formed by chlorite and minor amphiboles. These silicates are also found to be included within chromite grains (Fig. 6 B). Some samples show clear evidence of brittle to brittle-ductile deformation as exemplified by some fractured chromite grains, displaying similar structures to tension gashes (Fig. $6 \mathrm{C})$. Round-shaped chromites are also present, suggesting that they were corroded during ductile metamorphic/ deformation processes (Fig. 6 D). Several sulfide inclusions occur within chromite grains, represented by chalcopyrite, bornite and pentlandite (Fig. $6 \mathrm{D}, \mathrm{E}, \mathrm{F}$ and G).

Scanning electron microscopy (SEM) images and energy dispersive spectrometry (EDS) analyses of selected chromitite samples confirm that the main inclusions observed in reflected light microscopy are copper sulfides (Fig. 7 A, B, $C$ and $D$ ). Locally, some bismuth minerals were recognized within the chromite crystals, probably emplectite $\left(\mathrm{CuBiS}_{2}\right)$ or wittichenite $\left(\mathrm{Cu}_{3} \mathrm{BiS}_{3}\right)$ (Fig. $7 \mathrm{E}$ ). No PGM were recognized as enclosed within the chromite crystals, but locally, some high content of palladium has been found in association with sulfide inclusions (Fig. 7 F) (Pd-sulfide?). All the PGM that are recognized in these rocks are disseminated within the chlorite-serpentine matrix of the metachromitite, and at the chromite matrix boundary (Fig. $8 \mathrm{~A}, \mathrm{~B}, \mathrm{C}$ and D). Most of the PGM represent composite association, such as irarsite ((Ir, $\mathrm{Pt}, \mathrm{Rh}) \mathrm{AsS}$ ) crystals found within a cooperite (PtS) crystal (Fig. $8 \mathrm{~A})$. Sperrylite $\left(\mathrm{PtAs}_{2}\right)$ is the most common ore mineral, commonly occurring at the border of the chromite grains (Fig. 8 B). A composite grain of hollingworthite ((Rh,Pt)AsS) and irarsite ((IrPt,Rh)AsS) was found within the chlorite and serpentine grains of the metachromitite matrix (Fig. $8 \mathrm{C}$ ). Zircon grains were also identified in the metachromitite matrix, showing slightly rounded crystal habit and locally altered to xenotime (Fig. 8 D).
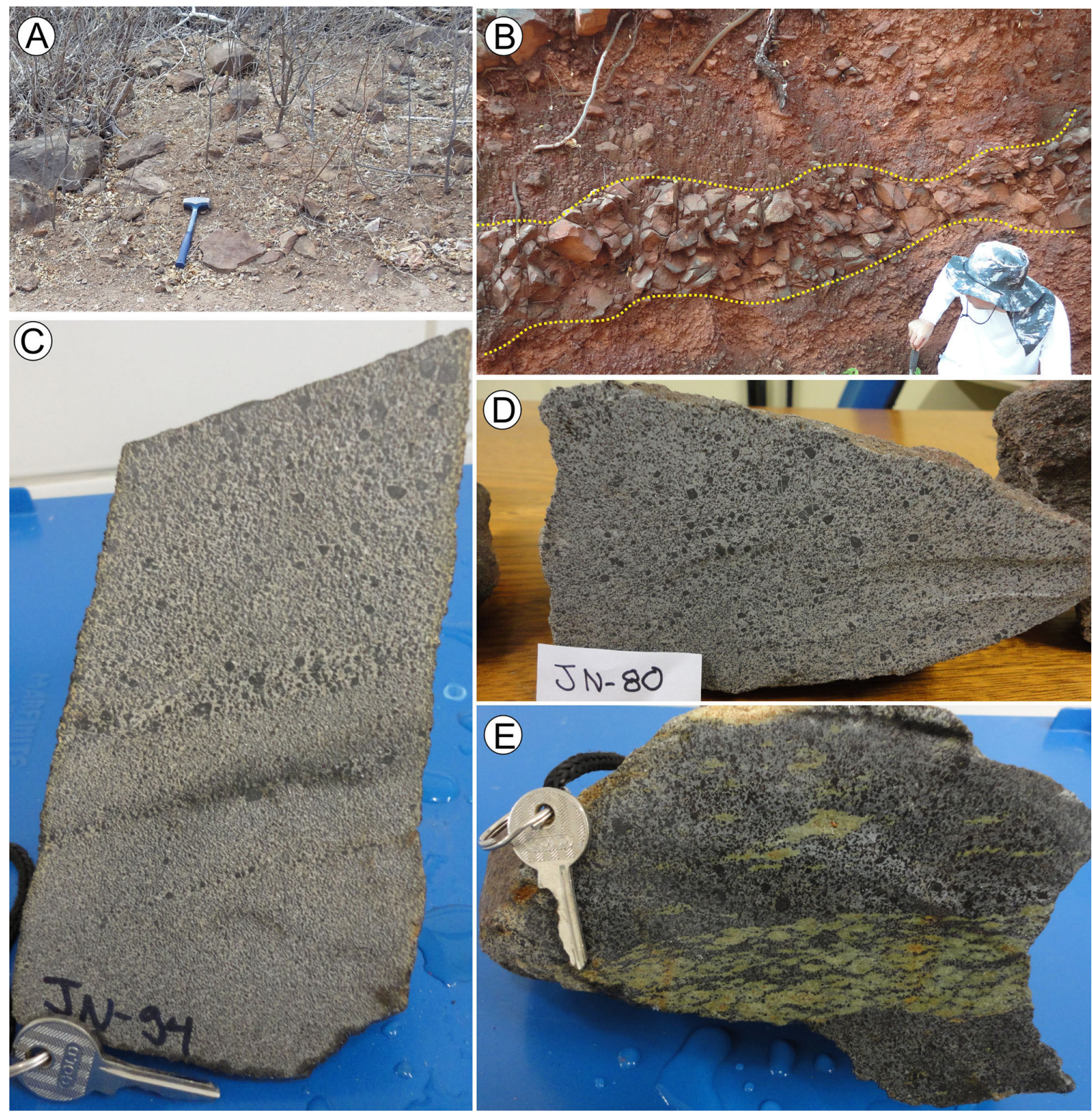

FIGURE 5. (A) Typical metachromitite outcrop of the Troia-Pedra Branca mafic-ultramafic complex. (B) Trench exposure of metachromitite layer within weathered metadunite. (C) Alternating coarse- and very fine-grained chromite layers showing cumulate texture with magmatic banding preserved in the metachromitite. (D) Metachromitite with homogeneous dissemination of chromite in chlorite-serpentine-bearing matrix. (E) Banded metachromitite sample with a silicate-rich layer composed of tremolite/actinolite (after clinopyroxene). 


\section{Whole-rock geochemistry}

Table 1 shows the major and trace element composition of the study metagabbros, metadunites and metachromitites. There are several trends among the major element oxides relative to $\mathrm{MgO}$ (wt.\%) contents (Fig. 9). The higher $\mathrm{MgO}$ contents (33.2 to $40.7 \mathrm{wt} . \%$ ) were found in the metadunites, followed by metachromitites ( $\mathrm{MgO}=13.4$ to 19.3 wt.\%) and metagabbros ( $\mathrm{MgO}=4.7$ to 10.6 wt.\%) (Fig. 9, Table

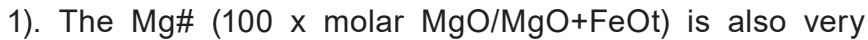
high in the metadunites (84.0 to 85.6) and relatively lower in the metachromitites (52.2 to 64.5) and metagabbros (50.1 to 64.0) (Table 1). Aluminum contents are high in the metagabbros $\left(\mathrm{Al}_{2} \mathrm{O}_{3}=13.8\right.$ to $\left.20.6 \mathrm{wt} . \%\right)$ and metachromitites $\left(\mathrm{Al}_{2} \mathrm{O}_{3}=13.5\right.$ to $\left.17.4 \mathrm{wt} . \%\right)$, and very low in the metadunites $\left(\mathrm{Al}_{2} \mathrm{O}_{3}=0.71\right.$ to 2.85 wt.\%) (Fig. 9, Table 1). $\mathrm{Al}_{2} \mathrm{O}_{3}$ contents for all investigated samples show a pronounced negative correlation with $\mathrm{MgO}$ contents (Fig. 9). The contents of $\mathrm{K}_{2} \mathrm{O}$

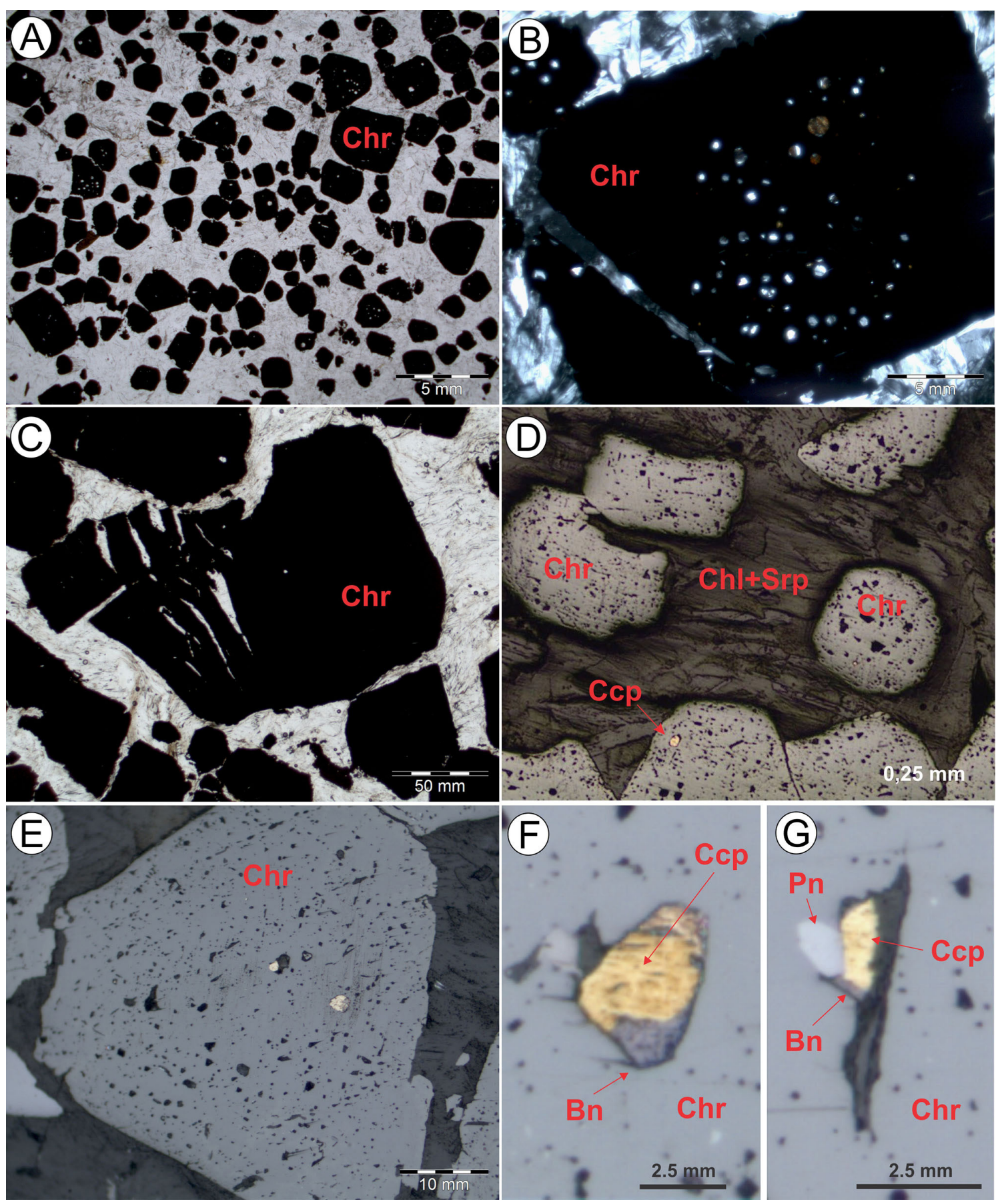

FIGURE 6. (A) Thin sections of metachromitite observed on a petrographic microscope with plain polarized light, showing the chromite (Chr) crystals with subhedral to anhedral shapes within a chlorite-serpentine matrix. (B) Poikilic texture of silicate inclusion within chromite (Chr) (cross polarized light). The interstitial silicates are chlorite, serpentine and minor amphiboles. (C) Photomicrograph (plain polarized light) showing a fractured chromite (Chr) crystal. (D) Photomicrograph taken in reflected light showing a chalcopyrite (Ccp) inclusion within rounded chromite. The matrix is dominantly composed of chlorite and serpentine (Chl+Srp). (E) Inclusions of chalcopyrite (yellow minerals) within chromite (Chr). $(F)$ and $(G)$ Photomicrograph (reflected light) showing composite inclusions of chalcopyrite (Ccp), bornite (Bn) and pentlandite (Pn). 

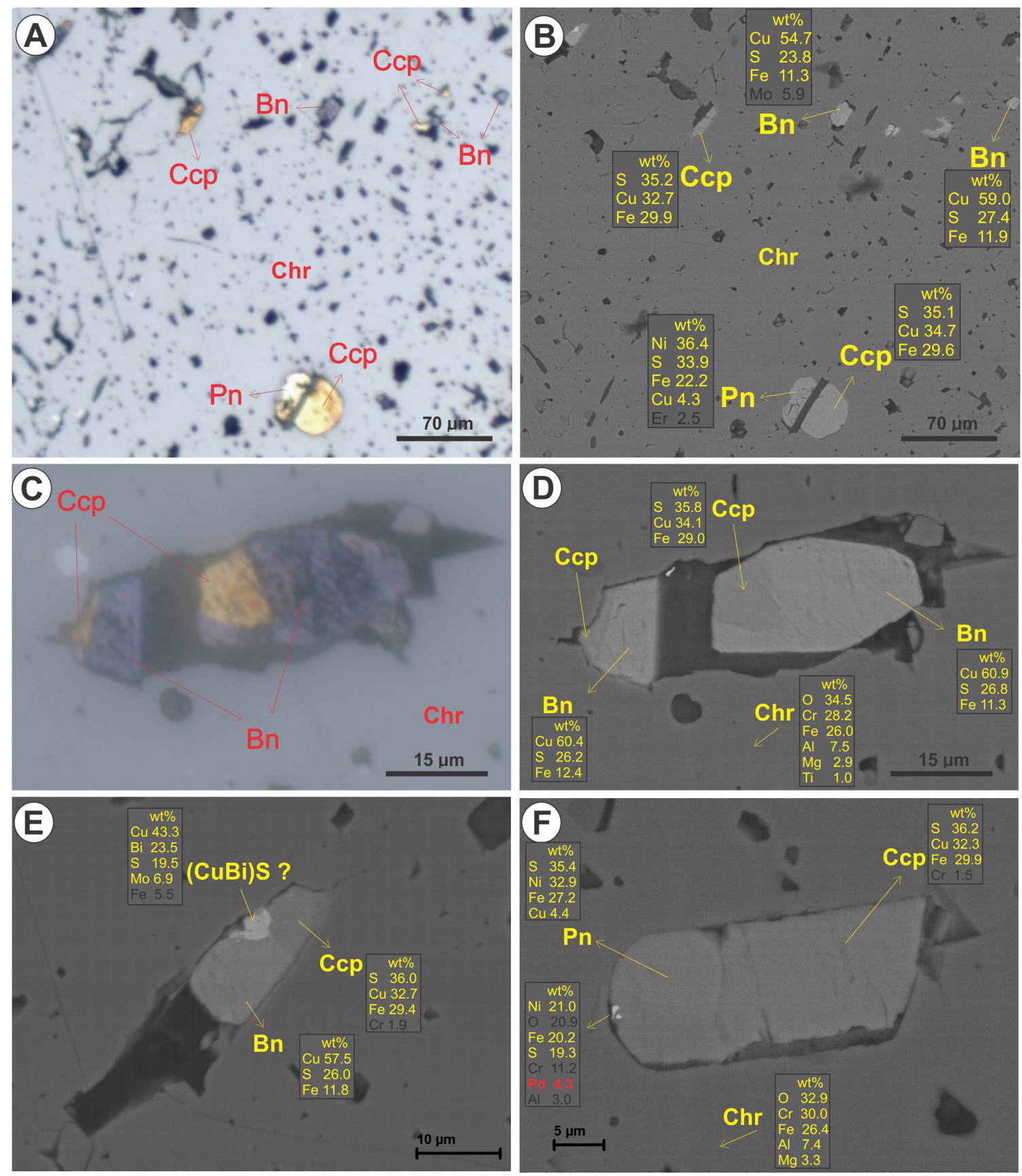

FIGURE 7. Photomicrographs of scanning electron microscope (SEM) images and energy dispersive spectrometry (EDS) analyses of metallic inclusions within chromites. (A) Thin section of a chromite $(\mathrm{Chr})$ grain in reflected light, with several sulfide inclusions $(\mathrm{Ccp}=$ chalcopyrite, $\mathrm{Bn}=$ bornite, $\mathrm{Pn}=$ pentlandite). (B) SEM-EDS information from the same view of Fig. $7 \mathrm{~A}$. (C) Thin section in reflected light showing a composite bornite $(\mathrm{Bn})$ - chalcopyrite (Ccp) inclusion within chromite (Chr). (D) SEM-EDS analyses from the same view of Fig. $7 \mathrm{C}$. (E) SEM-EDS analyses for bornite (Bn), chalcopyrite (Ccp) and a $\mathrm{Cu}-\mathrm{Bi}-\mathrm{S}$ mineral which could probably be emplectite (CuBiS2) or wittichenite (Cu3BiS3) (suphosalts). (F) SEM-EDS analyses of a composite bornite $(\mathrm{Bn})$ and pentlandite (Pn) inclusion within chromite, and a tiny composite mineral with traces of palladium $(\mathrm{Pd})(\mathrm{Pd}$-sulfide?). Some elements (\% in black) from the EDS analyses may represent contamination with the host mineral and/or small mineral phases

and $\mathrm{Na}_{2} \mathrm{O}$ are below the detection limit in the metadunites and metachromitites. In the metagabbros, they range from 0.27 to 0.92 wt.\% and 2.40 to 3.70 wt.\%, respectively (Fig. 9 , Table 1). The metachromitites have higher FeOt contents (17.9 to $21.9 \mathrm{wt} . \%)$ than the metadunites ( $\mathrm{FeOt}=11.2$ to 12.8 wt.\%) and metagabbros (FeOt $=6,60$ to 10,6 wt.\%), while the $\mathrm{TiO}_{2}$ contents are higher in the metagabbros $\left(\mathrm{TiO}_{2}=0.78\right.$ to 1.34 wt.\%) in comparison to metachromitites $\left(\mathrm{TiO}_{2}=0.35\right.$ to 0.37 wt.\%) and metadunites $\left(\mathrm{TiO}_{2}=0.03\right.$ to 0.07 wt.\%) (Fig. 9, Table 1).
Trace element contents also show significant variations among lithologies (Table 1). The $\mathrm{Ni}$ and Co contents are very high in the metadunites ( $\mathrm{Ni}=20303$ to $1690 \mathrm{ppm})$ and metachromitites ( $\mathrm{Ni}=1060$ to $1723 \mathrm{ppm}$ ), but relatively low in the metagabbros ( $\mathrm{Ni}=26$ to $136 \mathrm{ppm}, \mathrm{Co}=23$ to $50 \mathrm{ppm})$ (Fig. 10, Table 1). For the metadunites and metagabbros, the $\mathrm{Ni}$ and $\mathrm{Co}$ contents indicate a positive correlation with $\mathrm{MgO}$ (Fig. 10). Similarly, positive correlation trends were found for $\mathrm{Y}$ and $\mathrm{Yb}$ with $\mathrm{MgO}$ wt\% in the metagabbro, while the $\mathrm{Sr}$ contents show a negative correlation trend (Fig. 10). The 

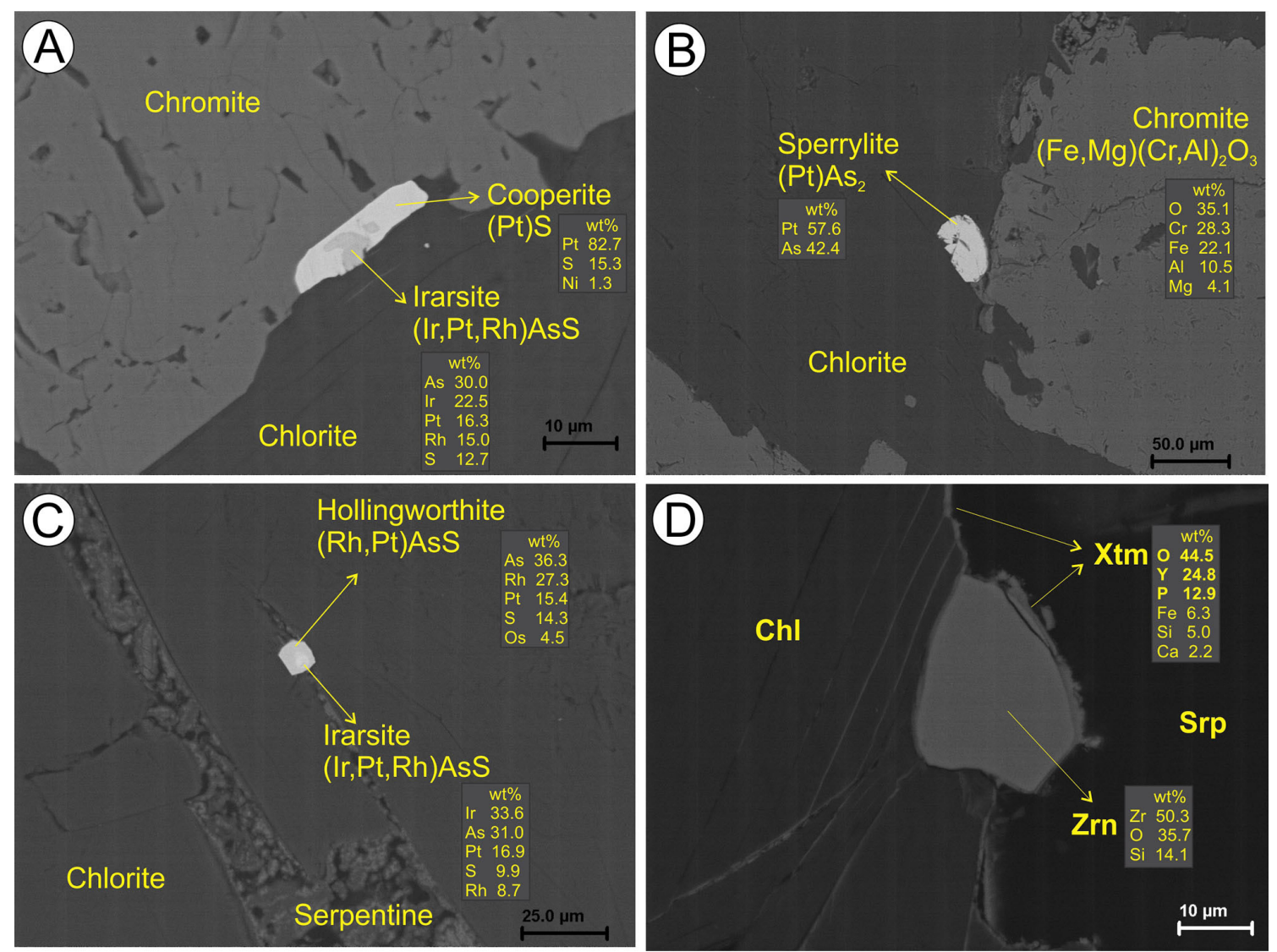

FIGURE 8. Electron backscatter images (SEM) and energy dispersive spectrometry (EDS) of PGM within the chromitite. (A) Amorphous irarsite

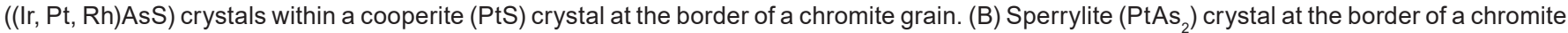
grain. (C) Composite crystal of hollingworthite ((Rh,Pt)AsS) and irarsite ((IrPt,Rh)AsS) within chlorite and serpentine crystals. (D) A zircon (Zrn) grain between chlorite (Chl) and serpentine (Srp) minerals, and xenotime (Xtm) mineral filling cleavage, fissures and grain boundaries.

Sr contents are very high in the metagabbros $(\mathrm{Sr}=708$ to $1615 \mathrm{ppm}$ ), and very low (close to the detection limit) in the metachromitites and metadunites (Fig. 10, Table 1). The Ba contents are also high in the metagabbros $(\mathrm{Ba}=674$ to 162 $\mathrm{ppm}$ ), low in the metadunites ( $\mathrm{Ba}=9$ to $21 \mathrm{ppm}$ ) and almost absent in the metachromitites (one sample with 28 ppm) (Fig. 10, Table 1).

In the "Total Alkalis" versus "Silica" (TAS) diagram, the metagabbros plot dominantly in the field of gabbros, with $\mathrm{SiO}_{2}$ contents in the range of basic rocks (Fig. 11 A). However, one sample (FC-124) plots in the field of dioritic rocks and another sample (FC-09) along the limit of gabbro and diorite field (Fig. $11 \mathrm{~A}$ ). Also, in the TAS diagram, all samples plot in the field of subalkaline/tholeiitic rocks according to the subdivision of Irvine and Baragar (1971). However, assuming the subdivision line of Kuno (1966), the metagabbros show a slight tendency to the alkaline field (Fig. $11 \mathrm{~A}$ ). In the $\mathrm{SiO}_{2}$ versus the $\mathrm{FeOt} / \mathrm{MgO}$ diagram for discrimination of tholeiite and calc-alkaline series from Miyashiro (1974), the samples of metagabbro plot predominantly in the field of the tholeiite series (Fig. 11 B). However, according to the $\mathrm{SiO}_{2}$ versus the $\mathrm{K}_{2} \mathrm{O}$ diagram with discrimination fields from Peccerillo and Taylar (1976) (Fig. $11 \mathrm{C}$ ) and the Th versus the Co discrimination diagram of Hastie et al. (2007) (Fig. 11 D), the samples of metagabbro plot predominantly in the field of calc-alkaline series.

The primitive mantle-normalized (Sun and McDonough, 1989) trace-element plots for the metagabbros are characterized by depletion in some of the high-field strength elements (HFSE), such as $\mathrm{Ti}, \mathrm{P}, \mathrm{Zr}$ and $\mathrm{Nb}$, and enrichment in some large ion lithophile elements (LILE), such as Cs, Ba, Th, K, $\mathrm{La}$ and $\mathrm{Sr}$ (Fig. 12 A). The positive Sr anomaly and the negative $\mathrm{Zr}, \mathrm{Nb}$ and $\mathrm{U}$ anomaly are the most pronounced features of the metagabbros in the primitive mantle-normalized plot (Fig. 12 A). The metadunites and metachromitites show similar patterns of LILE, compared to the metagabbros, showing a pronounced negative anomaly of $\mathrm{Rb}$ and positive Th anomaly (Fig. $12 \mathrm{~A}$ ). The metachromitites show a pronounced negative anomaly of $\mathrm{Sr}$ and positive $\mathrm{Ti}$ anomaly, while the metadunites show a negative Ti anomaly (Fig. $12 \mathrm{~A}$ ).

In the chondrite normalized diagram with Boynton (1984) values, the metagabbros exhibit enrichment in the light rare earth element (LREE) in comparison to heavy rare earth element (HREE) (Fig. 12 B). The metagabbro also shows a slightly positive Eu anomaly (Fig. $12 \mathrm{~B}$ ) and a steep pattern for the heavy rare earth elements (HREE) (Fig. $12 \mathrm{~B}$ ). In this diagram, the metachromitites and metadunites show a very similar pattern, with steep variation for their light rare earth elements (LREE) and a flat pattern for the HREE (Fig. 12 B). For the metachromitites, with exception of some LREE, the contents of REE are mostly lower than the chondrite values, and many were not detected by ICPMS analysis (Fig. 12 B, Table 1).

\section{Mineral chemistry}

The chromites analyzed in this study are from the Trapia deposit, in the southern part of the Troia-Pedra Branca mafic-ultramafic complex (Fig. $1 \mathrm{C}$ ). Chemical analysis 
TABLE 1. Whole-rock geochemical data.

\begin{tabular}{|c|c|c|c|c|c|c|c|c|c|c|c|c|c|c|c|}
\hline Sample & $\begin{array}{l}\text { FC-118 } \\
\text { gabbro }\end{array}$ & \begin{tabular}{|l|} 
FC-07 \\
gabbro
\end{tabular} & $\begin{array}{l}\text { FC-05 } \\
\text { gabbro }\end{array}$ & $\begin{array}{l}\text { FC-120 } \\
\text { gabbro }\end{array}$ & $\begin{array}{l}\text { FC-06A } \\
\text { gabbro }\end{array}$ & $\begin{array}{l}\text { FC-09 } \\
\text { gabbro }\end{array}$ & $\begin{array}{l}\text { FC-124 } \\
\text { gabbro }\end{array}$ & $\begin{array}{l}\mathrm{JN}-87 \\
\text { dunite }\end{array}$ & $\begin{array}{l}\text { JN-108 } \\
\text { dunite }\end{array}$ & \begin{tabular}{|l|} 
JN-94A \\
dunite
\end{tabular} & \begin{tabular}{|l|}
$\mathrm{JN}-94 \mathrm{~B}$ \\
dunite
\end{tabular} & $\begin{array}{l}\text { JN-108B } \\
\text { cromitite }\end{array}$ & $\begin{array}{l}\text { JN-91 } \\
\text { cromitite }\end{array}$ & $\begin{array}{l}\text { JN-87B } \\
\text { cromitite }\end{array}$ & $\begin{array}{l}\text { JN-88 } \\
\text { cromitite }\end{array}$ \\
\hline \multicolumn{16}{|c|}{ Major elements (wt\%) } \\
\hline $\mathrm{SiO}_{2}$ & 47.8 & 48.0 & 49.2 & 49.3 & 50.3 & 51.9 & 53.7 & 34.6 & 37.6 & 37.9 & 38.5 & 9.5 & 15.8 & 16.3 & 16.8 \\
\hline $\mathrm{TiO}_{2}$ & 1.05 & 1.34 & 1.05 & 1.04 & 0.79 & 1.00 & 0.78 & 0.07 & 0.07 & 0.02 & 0.03 & 0.35 & 0.37 & 0.35 & 0.35 \\
\hline $\mathrm{Al}_{2} \mathrm{O}_{3}$ & 13.8 & 14.1 & 19.5 & 17.5 & 20.6 & 18.3 & 15.7 & 2.5 & 2.9 & 0.7 & 1.3 & 15.9 & 13.5 & 14.6 & 17.4 \\
\hline $\mathrm{Fe}_{2} \mathrm{O}_{3}$ & 11.8 & 14.0 & 10.1 & 10.3 & 7.4 & 9.5 & 9.1 & 13.1 & 12.5 & 13.6 & 14.2 & 24.3 & 22.1 & 24.2 & 19.9 \\
\hline $\mathrm{MnO}$ & 0.19 & 0.22 & 0.18 & 0.18 & 0.10 & 0.15 & 0.16 & 0.18 & 0.18 & 0.17 & 0.17 & 0.42 & 0.24 & 0.26 & 0.20 \\
\hline $\mathrm{MgO}$ & 10.6 & 8.1 & 4.7 & 6.2 & 3.8 & 5.0 & 6.9 & 34.9 & 33.2 & 40.7 & 40.4 & 13.4 & 19.3 & 18.5 & 18.3 \\
\hline $\mathrm{BaO}$ & 0.0 & 0.0 & 0.0 & 0.1 & 0.1 & 0.0 & 0.1 & 0.0 & 0.0 & 0.0 & 0.0 & n.d. & n.d. & n.d. & n.d. \\
\hline $\mathrm{CaO}$ & 10.4 & 10.6 & 10.4 & 10.4 & 9.9 & 8.9 & 9.6 & 1.4 & 1.9 & 0.5 & 0.8 & 0.0 & $<0.01$ & 0.0 & 0.4 \\
\hline $\mathrm{Na}_{2} \mathrm{O}$ & 2.41 & 2.40 & 3.71 & 3.58 & 3.70 & 4.12 & 3.40 & n.d. & n.d. & n.d. & n.d. & n.d. & n.d. & n.d. & n.d. \\
\hline $\mathrm{K}_{2} \mathrm{O}$ & 0.27 & 0.40 & 0.34 & 0.92 & 0.51 & 0.40 & 0.62 & n.d. & n.d. & n.d. & n.d. & n.d. & n.d. & n.d. & n.d. \\
\hline $\mathrm{P}_{2} \mathrm{O}_{5}$ & 0.4 & 0.6 & 0.5 & 0.5 & 0.5 & 0.5 & 0.4 & 0.0 & 0.0 & 0.0 & 0.0 & 0.0 & 0.0 & 0.0 & 0.0 \\
\hline $\mathrm{Cr}_{2} \mathrm{O}_{3}$ & 0.1 & 0.0 & 0.0 & 0.0 & 0.0 & 0.0 & 0.0 & 0.9 & 1.8 & 0.8 & 0.8 & 34.5 & 24.7 & 21.3 & 21.7 \\
\hline LOI & 1.1 & 0.8 & 0.5 & 1.2 & 0.4 & 1.0 & 0.6 & 10.6 & 10.0 & 6.4 & 3.9 & 2.5 & 5.5 & 6.4 & 5.4 \\
\hline Total & 99.9 & 100.6 & 100.3 & 101.3 & 98.0 & 100.8 & 101.1 & 98.2 & 100.1 & 100.9 & 100.1 & 100.9 & 101.6 & 102.0 & 100.5 \\
\hline $\mathrm{mg} \#$ & 64.0 & 53.3 & 48.2 & 54.5 & 50.1 & 51.2 & 60.0 & 84.1 & 84.0 & 85.6 & 84.9 & 52.2 & 63.4 & 60.2 & 64.5 \\
\hline $\mathrm{FeOt}^{*}$ & 10.6 & 12.6 & 9.1 & 9.3 & 6.6 & 8.6 & 8.2 & 11.8 & 11.2 & 12.2 & 12.8 & 21.9 & 19.9 & 21.8 & 17.9 \\
\hline \multicolumn{16}{|c|}{ Trace elements (ppm) } \\
\hline $\mathrm{Ni}$ & 133 & 83 & 26 & 63 & 26 & 36 & 91 & 2062 & 1690 & 2238 & 2303 & 1160 & 1060 & 1162 & 1723 \\
\hline Co & 51 & 45 & 27 & 34 & 23 & 27 & 35 & 154 & 142 & 177 & 169 & 152 & 115 & 110 & 123 \\
\hline $\mathrm{Cr}$ & 479 & 274 & 137 & 205 & 137 & 68 & 274 & 6089 & 11974 & 5747 & 5268 & 236049 & 168997 & 145735 & 148471 \\
\hline $\mathrm{Cu}$ & 46 & 62 & n.d. & 77 & 67 & 29 & 41 & 34 & 8 & 71 & 182 & 6 & 8 & 132 & 266 \\
\hline $\mathrm{Rb}$ & 2.0 & 30.0 & 1.4 & 50.9 & 5.9 & 11.8 & 13.1 & n.d. & n.d. & 0.3 & 0.2 & 0.4 & 0.3 & 1.1 & 0.5 \\
\hline $\mathrm{Sr}$ & 708 & 966 & 1229 & 1405 & 1615 & 1167 & 1366 & 28 & 15 & 6 & 4 & 2 & 2 & 2 & 2 \\
\hline $\mathrm{Ba}$ & 208 & 266 & 273 & 648 & 674 & 162 & 418 & 9 & n.d. & 9 & n.d. & 28 & n.d. & n.d. & n.d. \\
\hline Th & 2.2 & 4.2 & 8.3 & 1.5 & 3.5 & 2.5 & 0.5 & 2.9 & 2.3 & 4.5 & 3.8 & 13.1 & 1.6 & 2.0 & 2.2 \\
\hline $\mathrm{Nb}$ & 3.3 & 2.8 & 7.1 & 1.8 & 2.9 & 2.5 & 1.8 & 2.1 & 1.1 & 10.3 & 6.2 & 2.8 & 0.6 & 0.9 & 0.7 \\
\hline $\mathrm{Zr}$ & 26 & 24 & 34 & 25 & 21 & 23 & 38 & n.d. & n.d. & n.d. & n.d. & 6 & n.d. & n.d. & n.d. \\
\hline$Y$ & 20.0 & 18.7 & 16.4 & 20.0 & 10.7 & 14.6 & 17.0 & 1.5 & 2.5 & 1.2 & 1.3 & 0.5 & 0.3 & 0.5 & 1.1 \\
\hline $\mathrm{Ta}$ & n.d. & n.d. & n.d. & n.d. & n.d. & n.d. & n.d. & n.d. & n.d. & 0.4 & 0.2 & 0.6 & n.d. & n.d. & n.d. \\
\hline $\mathrm{Hf}$ & 0.8 & 0.7 & 1.3 & 0.4 & 0.5 & 0.4 & 0.6 & 0.2 & 0.2 & 0.7 & 0.4 & 2.3 & n.d. & 0.1 & 0.1 \\
\hline $\mathrm{Ga}$ & 17.2 & 19.0 & 22.2 & 21.4 & 22.8 & 20.2 & 18.3 & 2.9 & 4.1 & 1.8 & 2.1 & 17.8 & 19.0 & 17.7 & 26.3 \\
\hline U & 0.1 & 0.1 & n.d. & 0.1 & 0.1 & 0.1 & 0.1 & 0.1 & 0.1 & 1.4 & 0.2 & 0.3 & 0.6 & 0.6 & 1.3 \\
\hline \multicolumn{16}{|c|}{ Rare Earth Elements (ppm) } \\
\hline La & 8.7 & 12.8 & 15.5 & 18.5 & 12.0 & 14.9 & 14.5 & 1.6 & 1.4 & 10.6 & 5.0 & 1.5 & 0.5 & 1.5 & 5.2 \\
\hline $\mathrm{Ce}$ & 22.5 & 26.2 & 32.5 & 37.5 & 21.6 & 24.8 & 30.7 & 2.4 & 2.1 & 5.3 & 4.5 & 1.6 & 1.1 & 1.4 & 2.6 \\
\hline $\mathrm{Pr}$ & 3.6 & 3.8 & 4.4 & 5.1 & 2.9 & 3.5 & 4.2 & 0.2 & 0.2 & 0.4 & 0.3 & 0.1 & 0.1 & 0.1 & 0.2 \\
\hline $\mathrm{Nd}$ & 17.4 & 19.3 & 19.8 & 21.7 & 13.9 & 16.6 & 17.4 & 0.8 & 0.9 & 1.8 & 1.3 & 0.5 & 0.2 & 0.4 & 0.8 \\
\hline $\mathrm{Sm}$ & 4.3 & 4.6 & 4.3 & 4.8 & 3.2 & 3.6 & 3.8 & 0.2 & 0.2 & 0.3 & 0.2 & 0.1 & n.d. & n.d. & 0.2 \\
\hline Eu & 1.6 & 1.5 & 1.8 & 1.8 & 1.6 & 1.6 & 1.4 & n.d. & n.d. & 0.1 & n.d. & n.d. & n.d. & n.d. & n.d. \\
\hline $\mathrm{Gd}$ & 4.4 & 4.5 & 4.0 & 4.5 & 2.8 & 3.7 & 3.6 & 0.3 & 0.4 & 0.3 & 0.2 & 0.2 & 0.1 & 0.1 & 0.2 \\
\hline $\mathrm{Tb}$ & 0.6 & 0.6 & 0.6 & 0.6 & 0.4 & 0.5 & 0.5 & n.d. & 0.1 & n.d. & n.d. & n.d. & n.d. & n.d. & n.d. \\
\hline Dy & 3.7 & 3.7 & 3.2 & 3.6 & 2.1 & 2.8 & 3.0 & 0.2 & 0.4 & 0.2 & 0.2 & n.d. & n.d. & 0.1 & 0.2 \\
\hline Ho & 0.7 & 0.7 & 0.6 & 0.7 & 0.4 & 0.5 & 0.6 & n.d. & 0.1 & n.d. & n.d. & n.d. & n.d. & n.d. & n.d. \\
\hline $\mathrm{Er}$ & 2.0 & 1.9 & 1.6 & 1.8 & 1.0 & 1.5 & 1.6 & 0.2 & 0.3 & 0.1 & 0.2 & n.d. & n.d. & 0.1 & 0.2 \\
\hline $\mathrm{Tm}$ & 0.3 & 0.3 & 0.2 & 0.3 & 0.2 & 0.2 & 0.2 & n.d. & n.d. & n.d. & n.d. & n.d. & n.d. & n.d. & n.d. \\
\hline $\mathrm{Yb}$ & 1.7 & 1.6 & 1.3 & 1.6 & 0.8 & 1.2 & 1.5 & 0.2 & 0.3 & n.d. & n.d. & n.d. & n.d. & n.d. & n.d. \\
\hline Lu & 0.2 & 0.2 & 0.2 & 0.2 & 0.1 & 0.2 & 0.2 & n.d. & n.d. & n.d. & n.d. & n.d. & n.d. & n.d. & n.d. \\
\hline
\end{tabular}




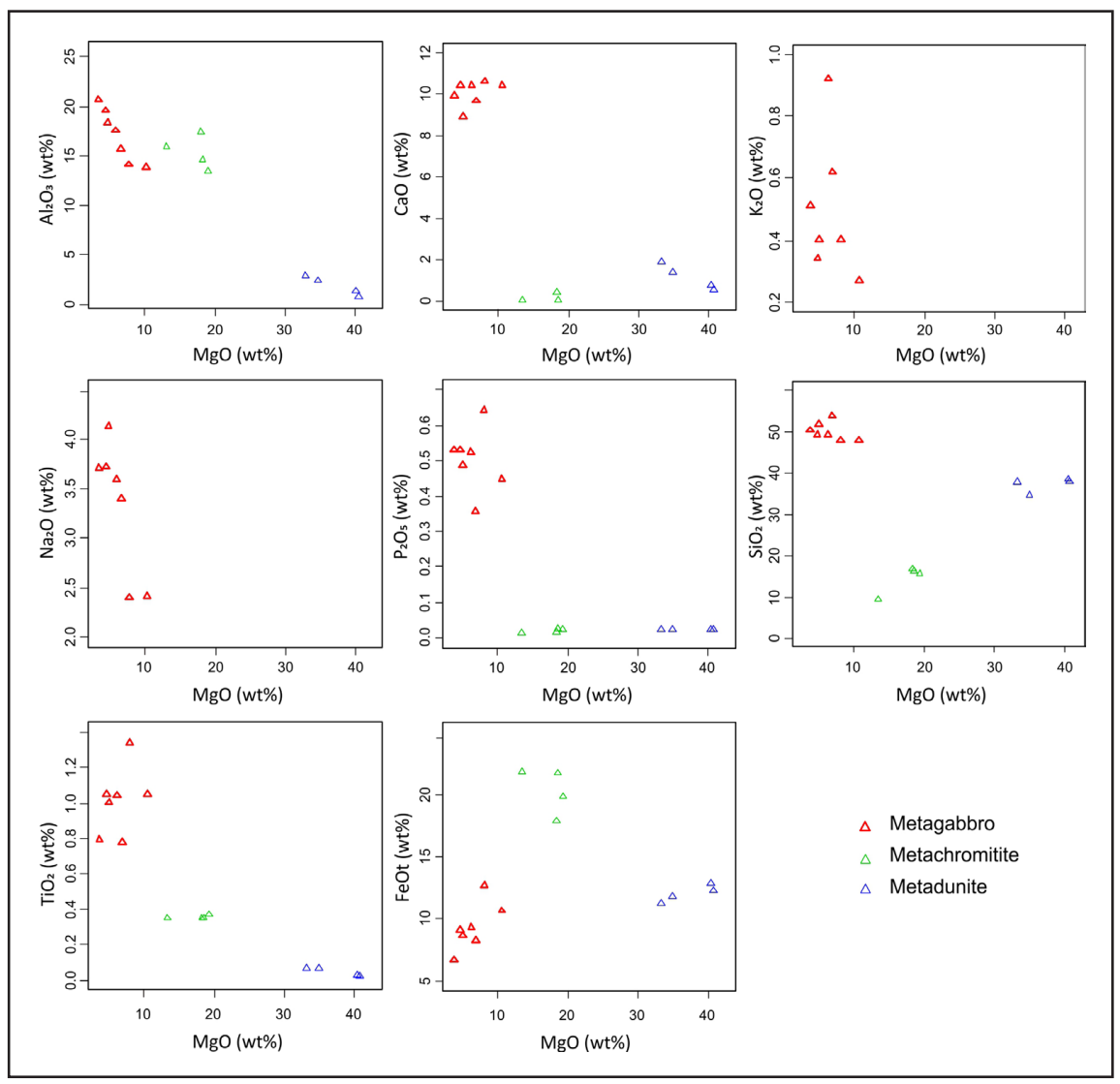

FIGURE 9. Major elements $\left(\mathrm{Al}_{2} \mathrm{O}_{3}, \mathrm{CaO}, \mathrm{K}_{2} \mathrm{O}, \mathrm{Na}_{2} \mathrm{O}, \mathrm{P}_{2} \mathrm{O}_{5}, \mathrm{SiO}_{2}, \mathrm{TiO}_{2}, \mathrm{FeOt}\right)$ wt.\% versus $\mathrm{MgO}$ $\mathrm{wt} . \%$ contents from representative rocks of the Troia-Pedra Branca mafic-ultramafic complex.

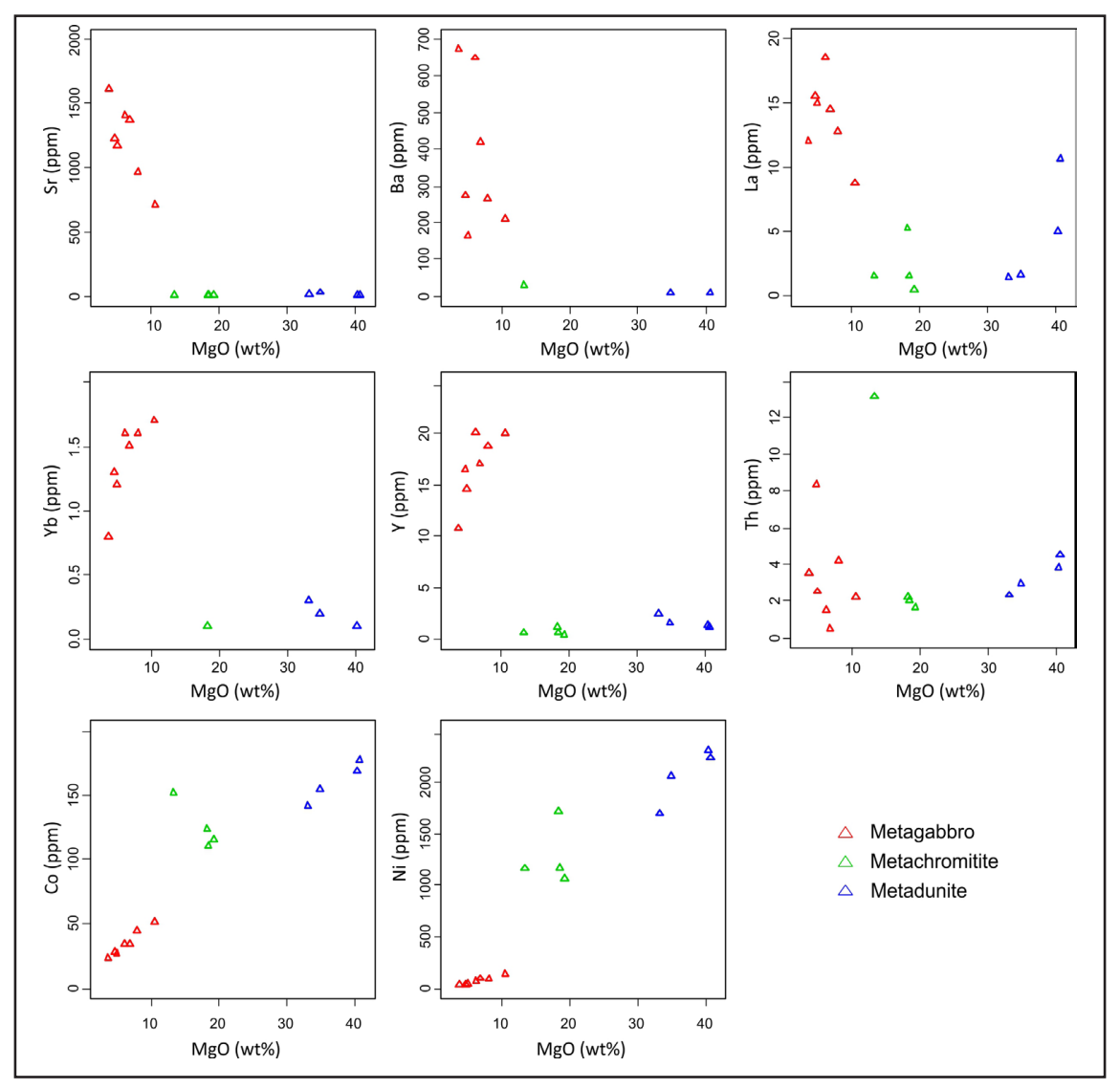

FIGURE 10. Trace elements ( $\mathrm{Sr}, \mathrm{Ba}, \mathrm{La}, \mathrm{Yb}, \mathrm{Y}, \mathrm{Th}, \mathrm{Co}$ and $\mathrm{Ni}$ ) in ppm versus $\mathrm{MgO}$ wt.\% contents from representative rocks of the Troia-Pedra Branca mafic-ultramafic complex. 

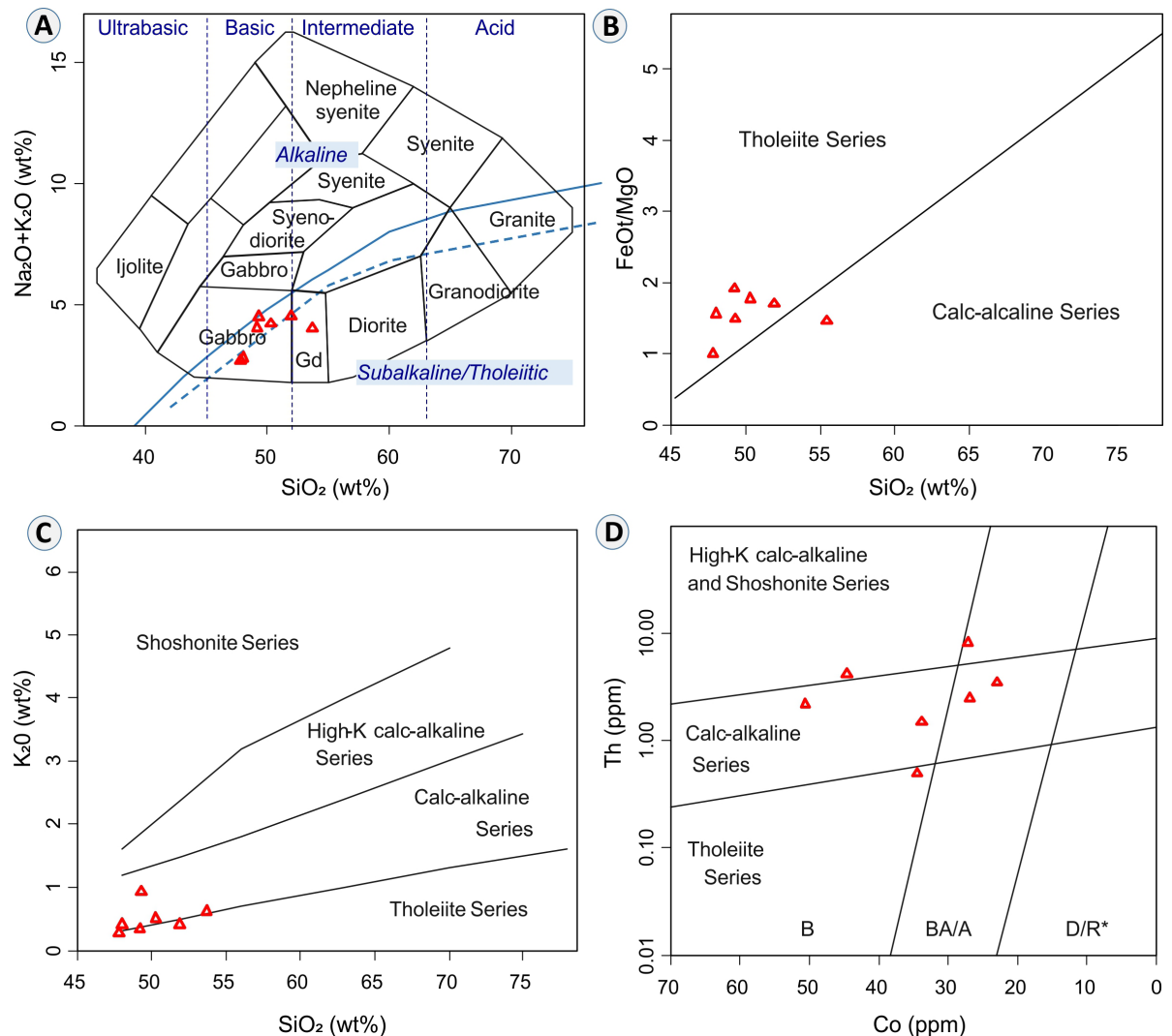

FIGURE 11. (A) Total alkalis versus silica (TAS) diagram with the field of plutonic rocks from Cox et al. (1979) and subdivision lines for alkaline and subalkaline series from Kuno (1966) (dashed line) and Irvine and Baragar (1971) (solid line) ( $\mathrm{Gd}=\mathrm{Gabbro-diorite).} \mathrm{(B)} \mathrm{SiO}_{2}$ versus $\mathrm{FeOt} / \mathrm{MgO}$ diagram for discrimination of tholeiite and calc-alkaline series from Miyashiro (1974). (C) $\mathrm{SiO}_{2}$ versus $\mathrm{K}_{2} \mathrm{O}$ diagram with discrimination fields for magmatic series from Peccerillo and Taylar (1976). (D) Th versus Co discrimination diagram of Hastie et al. (2007) for the Troia-Pedra Branca metagabbros ( $B=$ basalt, BA/A= basaltic andesite/ andesite, $\mathrm{CA}=$ calc-alkaline, $\mathrm{D} / \mathrm{R}=$ dacite/rhyolite).
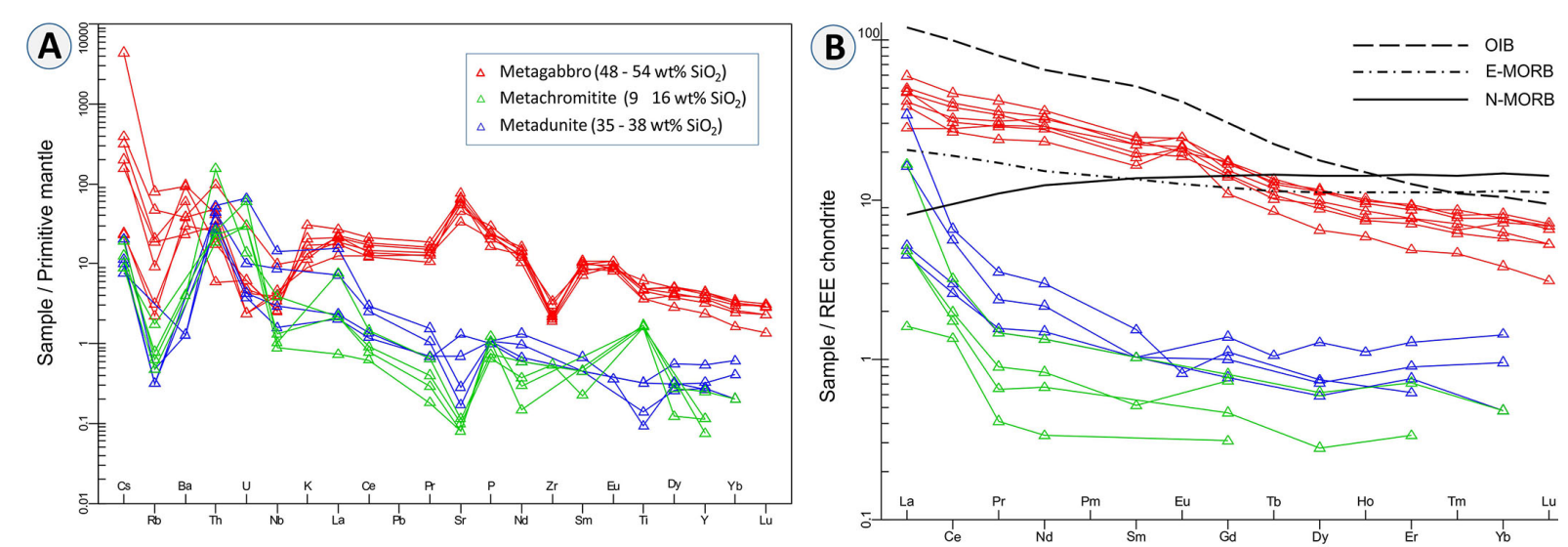

FIGURE 12. (A) Multi-element diagram normalized to the primitive mantle according to Sun and Mcdonough (1989). (B) Rare earth elements (REE) normalized by chrondrite according to Boyton (1984). The values for ocean island basalts (OIB), normal-mid ocean ridge basalts (N-MORB) and enriched mid-ocean ridge basalts (E-MORB) are also from Sun and Mcdonough (1989). 
of chromite for the Troia-Pedra Branca metachromitites sourced from the literature is presented for comparison (Fig. 13). The chromites display several compositional variations on their major element contents, especially with respect to $\mathrm{Mg}^{2+}, \mathrm{Fe}^{2+}, \mathrm{Cr}^{3+}, \mathrm{Fe}^{3+}, \mathrm{Al}^{3+}$ and $\mathrm{Ti}^{4+}$ (Fig. 13, Table 2). The chromites are classified as "true" chromites, according to their $\mathrm{Cr} \#=\mathrm{Cr} /(\mathrm{Cr}+\mathrm{Al})$ and $\mathrm{Mg \#}=\mathrm{Mg} /\left(\mathrm{Mg}+\mathrm{Fe}^{2+}\right)$ contents in the classification diagram of Schulze (2001) (Fig. 13 A). The chromite cores show $\mathrm{Cr} \#$ values from 0.59 to 0.64 , whereas the rims show higher $\mathrm{Cr}$ \# values of 0.73 to 0.80 (Fig. $13 \mathrm{~A}$, Table 2). The Mg\# varies from 0.28 to 0.36 in the cores and is much lower in the chromite rims $(0.23$ to 0.25$)$ (Fig. $13 \mathrm{~A}$, Table 2). Also, the chromite core and rims display a clear correlation trend, with $\mathrm{Mg \#}$ lowering toward $\mathrm{Cr} \#$ enrichment (Fig. $13 \mathrm{~A}$ ). Similarly, the plots of $\mathrm{MgO}, \mathrm{Al}_{2} \mathrm{O}_{3}$, and $\mathrm{Fe}^{2+}$ versus that of $\mathrm{Cr}_{2} \mathrm{O}_{3}$ also show pronounced correlation trends (Fig. $13 \mathrm{~B}, \mathrm{C}$ and $\mathrm{D}$ ). The $\mathrm{MgO}$ contents of the chromites range from 5.51 to $7.4 \mathrm{wt} . \%$ in the cores and from 4.27 to $4.77 \mathrm{wt} . \%$ at the rims (Fig. $13 \mathrm{~B}$, Table 2). The $\mathrm{Al}_{2} \mathrm{O}_{3}$ contents are higher in the chromite cores (from 16.22 to $19.31 \mathrm{wt} . \%$ ), whereas the rims show much lower values (from 8.79 to 11.78 wt.\%) (Fig. $13 \mathrm{C}$, Table 2). In contrast, the calculated $\mathrm{Fe}^{2+}$ (a.p.f.u.) shows a pronounced enrichment toward the chromite rims (Fig. 13 D). The $\mathrm{TiO}_{2}$ (wt.\%) contents of the chromite grains show no variation from core (0.15 to 0.49 wt.\%) to rim (0.17 to 0.46 wt.\%) (Fig. 13 E, Table 2).

Olivine from metadunites of the Troia-Pedra Branca mafic-ultramafic complex shows little variations in the major element contents, with $\mathrm{SiO}_{2}$ ranging from 39.98 to 40.42 wt.\%, FeOt from 14.30 to 14.70 wt.\%, MgO between 44.34 and 44.66 wt.\%) and $\mathrm{NiO}$ from 0.34 to 0.42 wt.\% (Table 3). The forsterite content of olivine $\left(\mathrm{Fo}=\mathrm{Mg} /\left(\mathrm{Mg}+\mathrm{Fe}^{2+}\right)\right.$ from the study metadunite is high and shows very little variation (Fo $=$ 0.84 to 0.85 ) (Table 3 ).

\section{U-Pb (SHRIMP) zircon age}

The study zircon crystals were extracted from a sample (JN-88, UTM 404668, 9388657, 24S) of metachromitite from the Curiu deposit (Fig. $1 \mathrm{C}$ ). On a mesoscopic scale, this metachromitite sample exhibits well-layered features, with alternating massive chromite and silicate-rich layers. The zircon crystals are quite homogeneous, with an average size of $\sim 50 \mu \mathrm{m}$, irregular borders and sub rounded shapes (Fig. 14). This oval-shaped zircon grains were also found in thin section, within the serpentine-chlorite matrix of the metachromitite (Fig. $8 \mathrm{D}$ ). In the cathodoluminescense image, the grains show discrete development of the core-rim relationship, and they generally show a "smoky" internal structure, with diffuse oscillatory zoning (Fig. 14).

The SHRIMP U-Pb data for zircons from the Troia-Pedra Branca metachromitite are variably discordant (with 60 to $105 \%$ of concordance) (Table 4). The U-Pb data plot mostly along the discordia line with only four concordant zircon grains (Fig. 15, Table 4). The discordia line yields an upper intercept age of 2036 $\pm 27 \mathrm{Ma}$ (Fig. 15), interpreted as the crystallization age of these zircon grains. However, the dispersion of the data along the discordia line implies that the zircons have lost variable amounts of radiogenic $\mathrm{Pb}$ at about $749 \pm 54 \mathrm{Ma}$ (lower intercept) (Fig. 15). The calculated 2036 Ma upper intercept age yields a Mean Square Weighted Deviation (MSWD) of 1.2 ( $n=13$ zircons) (Fig. 15). The $T h / U$ ratios range from 0.20 to 0.46 (Table 4 ).

\section{Discussion}

\subsection{PGE mineralization and metamorphism}

All rock types of the Troia-Pedra Branca mafic-ultramafic complex are variably deformed and metamorphosed along the regional folding and shearing systems (Fig. 1 C) (Pessoa et al. 1986, Oliveira and Cavalcante 1993). Therefore, it is very hard to reconstruct the original shape of the mafic-ultramafic complex, as it is now strongly disrupted as tabular sheared layers, and locally intruded by sheet-like S-type granites (Fig. 1 C) (Pessoa et al. 1986, Oliveira and Cavalcante 1993). The mafic-ultramafic complex underwent metamorphic processes of upper greenschist to lower amphibolite facies conditions, probably during the Paleoproterozoic (ca. 2.1-2.0 Ga) and/or the Neoproterozoic (ca. 0.6-0.5 Ga) (Pessoa et al. 1986). The igneous mineralogy of all rocks was strongly modified by the tectonic-metamorphic processes, resulting in a succession of sheared serpentinites (after dunite), metaperidotites (after clinopiroxenite), hornblendites, hornblende metagabbros and metagabbro-diorites (Pessoa et al. 1986, Oliveira and Cavalcante 1993).

The PGE-bearing metachromitites are hosted by the metadunite unit (Barrueto and Hunt 2010). This study has confirmed that most of the PGM occur in the chlorite-serpentine matrix, generally in contact with chromite grains (Fig. 8), as reported by previous works (Angeli 2005, Angeli et al. 2009, Barrueto and Hunt 2010). The main PGM here recognized are sperrylite $\left(\mathrm{PtAs}_{2}\right)$, cooperite $(\mathrm{PtS})$, irarsite $((\mathrm{Ir}, \mathrm{Pt}, \mathrm{Rh}) \mathrm{AsS})$ and hollingworthite ((Rh,Pd,Pt,Ru)AsS) (Fig. 8). However, other authors reported the presence of braggite ((Pt,Pd,Ni)S), laurite (RuS $_{2}$ ) and kotulskite (PdTe) (Angeli 2005, Angeli et al. 2009, Barrueto and Hunt 2010). Within the chromite grains, no PGM were found, and the main sulfide inclusions are chalcopyrite $\left(\mathrm{CuFeS}_{2}\right)$, pentlandite $\left((\mathrm{Fe}, \mathrm{Ni})_{9} \mathrm{~S}_{8}\right)$ and bornite $\left(\mathrm{Cu}_{5} \mathrm{FeS}_{4}\right)$ (Fig. 7). Also, very few sulfides were found within the metachromitite matrix. Sulfide inclusions within chromite crystals are generally interpreted as a primary phase, and are commonly thought to form as sulfide blebs in the magma, prior to the host chromite (e.g., Melcher et al. 1997, Naldrett et al. 2009, Liu et al. 2017). However, post-magmatic sulfides may also occur in recrystallized chromites, resulting from a sulfidation reaction. In this context, sulfide inclusions are closely associated with silicates (Lorand and Ceuleneer 1989, Melcher et al. 1997). The sulfide inclusions in our samples are chalcopyrite, pentladite and bornite, and they are not associated with silicate minerals (Fig. 6 and 7). Consequently, these sulfides may have been formed by the separation of an immiscible sulfide liquid (blebs) in the mafic-ultramafic magma, earlier and/or during the chromite precipitation.

Chromite recrystallization and fluid-assisted metamorphism of the Troia-Pedra Branca complex have been documented in detail (Fleet et al. 1993, Simões 1993). All silicate inclusions in the chromite grains are metamorphic minerals, such as serpentine (after olivine), chlorite and minor amphiboles, and no primary silicate was found within the chromites (Fig. 6 C). According to Fleet et al. (1993), all silicate inclusions found in the Troia-Pedra Branca chromites are the product of low-grade metamorphic alteration of pre-existing primary silicate inclusions. The chlorite inclusions, and also the chlorite that comprises the serpentine-chlorite matrix of the Troia-Pedra Branca metachromitites, were characterized by 
TABLE 2. Chromite mineral chemistry from the Troia-Pedra Branca metachromitite.

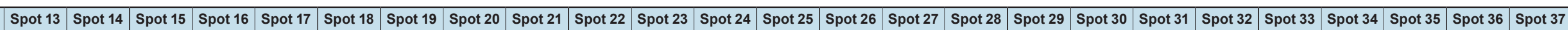

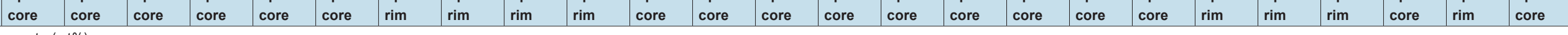
Major elements (wt\%)

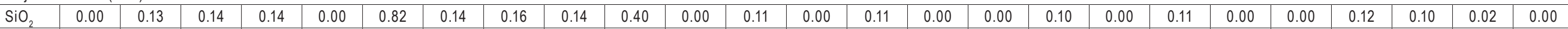

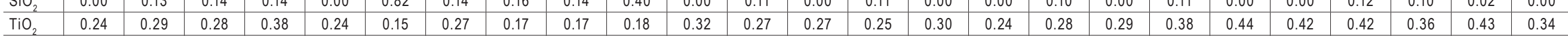

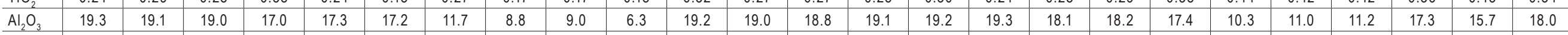

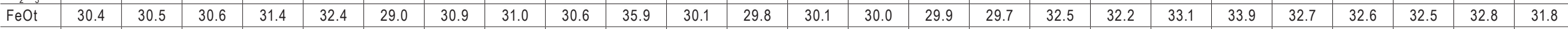

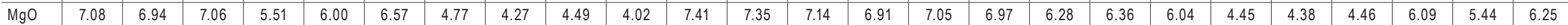

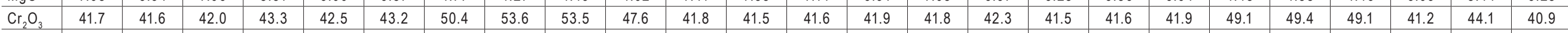

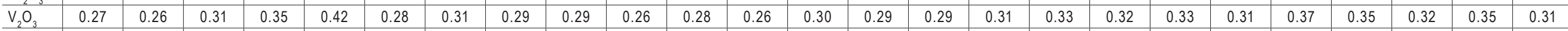

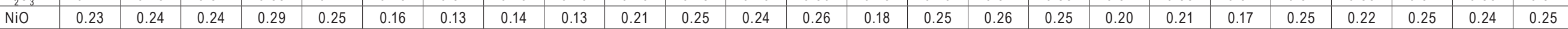

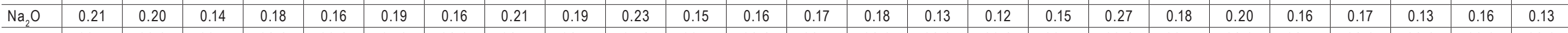

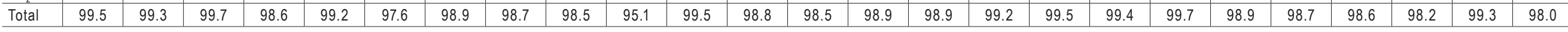
a.p.f.u. (4 oxygen)

\begin{tabular}{|c|c|c|c|c|c|c|c|c|c|c|c|c|c|c|c|c|c|c|c|c|c|c|c|c|c|}
\hline i & 0.00 & 0.00 & 0.00 & 0.00 & 0.00 & 0.03 & 0.00 & 0.01 & 0.00 & 0.02 & 0.00 & 0.00 & 0.00 & 0.00 & 0.00 & 0.00 & 0.00 & 0.00 & 0.00 & 0.00 & 0.00 & 0.00 & 0.00 & 0.00 & 0.00 \\
\hline Ti & .01 & 0.01 & 0.01 & 0.01 & 0.01 & 0.00 & 0.01 & .00 & 0.00 & 0.01 & 0.01 & 0.01 & 0.01 & 0.01 & 0.01 & 0.01 & 0.01 & 0.01 & 0.01 & 0.01 & 0.01 & 0.01 & 0.01 & 0.01 & 0.01 \\
\hline & 75 & 0.75 & 0.74 & 0.68 & 0.69 & 0.69 & 0.48 & 37 & 0.38 & 28 & 0.75 & 75 & 75 & .75 & 1.75 & 0.75 & 0.72 & 0.72 & 0.69 & .43 & .46 & 0.46 & 0.70 & 0.63 & 0.72 \\
\hline$e^{3+}$ & 0.19 & 0.18 & 0.18 & 0.17 & 0.21 & 0.13 & 0.14 & 0.15 & 0.14 & .33 & 0.19 & 0.18 & 0.17 & 0.17 & 0.17 & 0.16 & 0.21 & 0.22 & 0.22 & 0.23 & 0.19 & 0.18 & 0.22 & 0.20 & 0.21 \\
\hline $\mathrm{e}^{2+}$ & 0.65 & 0.66 & 0.67 & 0.73 & 0.71 & 0.69 & 0.76 & 0.77 & 0.76 & 0.81 & 0.65 & 0.65 & 0.66 & 0.66 & 0.66 & 0.66 & 0.70 & 0.68 & 0.72 & 0.78 & 0.78 & 0.78 & 0.71 & 0.74 & 0.70 \\
\hline $\mathrm{Mg}$ & 0.35 & 0.34 & 0.35 & 0.28 & 0.30 & 0.33 & 0.25 & 0.23 & 0.24 & 0.23 & 0.37 & 0.37 & 0.34 & 0.34 & 0.35 & 0.34 & 0.31 & 0.32 & 0.30 & 0.24 & 0.23 & 0.23 & 0.31 & 0.28 & 0.32 \\
\hline $\mathrm{Cr}$ & 1.09 & 1.09 & 1.10 & 1.17 & 1.14 & 1.16 & 1.39 & 1.50 & 1.50 & 1.43 & 1.09 & 1.09 & 1.10 & 1.10 & 1.10 & 1.11 & 1.10 & 1.10 & 1.12 & 1.38 & 1.38 & 1.37 & 1.11 & 1.19 & 1.10 \\
\hline V & 0.01 & 0.01 & 0.01 & 0.01 & 0.01 & 0.01 & 0.01 & 0.01 & 0.01 & 0.01 & 0.01 & 0.01 & 0.01 & 0.01 & 0.01 & 0.01 & 0.01 & 0.01 & 0.01 & 0.01 & 0.01 & 0.01 & 0.01 & 0.01 & 0.01 \\
\hline $\mathrm{Ni}$ & 0.01 & 0.01 & 0.01 & 0.01 & 0.01 & 0.00 & 0.00 & 0.00 & 0.00 & 0.01 & 0.01 & 0.01 & 0.00 & 0.00 & 0.01 & 0.01 & 0.01 & 0.01 & 0.01 & 0.00 & 0.01 & 0.01 & 0.01 & 0.01 & 0.01 \\
\hline va & 0.01 & 0.01 & 0.01 & 0.01 & 0.01 & 0.01 & 0.01 & 0.01 & 0.01 & 0.02 & 0.01 & 0.01 & 0.01 & 0.01 & 0.01 & 0.01 & 0.01 & 0.02 & 0.01 & 0.01 & 0.01 & 0.01 & 0.01 & 0.01 & 0.01 \\
\hline Cr\#\# & 0.59 & 0.59 & 0.60 & 0.63 & 0.62 & 0.63 & 0.74 & 0.80 & 0.80 & 0.84 & 0.59 & 0.59 & 0.60 & 0.60 & 0.59 & 0.60 & 0.61 & 0.61 & 0.62 & 0.76 & 0.75 & 0.75 & 0.61 & 0.65 & 0.60 \\
\hline lg\#2 & 0.35 & 0.34 & 0.34 & 0.28 & 0.30 & 0.32 & 0.25 & 0.23 & 0.24 & 0.22 & 0.36 & 0.36 & 0.34 & 0.34 & 0.35 & 0.34 & 0.31 & 0.32 & 0.30 & 0.23 & 0.23 & 0.23 & 0.30 & 0.27 & 0.31 \\
\hline e\#3 & 0.09 & 0.09 & 0.09 & 0.08 & 0.10 & 0.07 & 0.07 & & 0.07 & 0.16 & 0.09 & 0.09 & 0.08 & 0.08 & 0.09 & 0.08 & 0. & 0.11 & 0. & 0 & 0.09 & 0.09 & 0.11 & 0.10 & 0.10 \\
\hline Fe\#2 & 0.65 & 0.66 & 0.66 & 0.72 & 0.70 & 0.68 & 0.75 & 0.77 & 0.76 & 0.78 & 0.64 & 0.64 & 0.66 & 0.66 & 0.65 & 0.66 & 0.69 & 0.68 & 0.70 & 0.77 & 0.77 & 0.77 & 0.70 & 0.73 & 0.69 \\
\hline & $\begin{array}{l}\text { Spot } 38 \\
\text { core }\end{array}$ & $\begin{array}{l}\text { Spot } 39 \\
\text { core }\end{array}$ & $\begin{array}{l}\text { Spot } 40 \\
\text { core }\end{array}$ & $\begin{array}{l}\text { Spot } 41 \\
\text { core }\end{array}$ & $\begin{array}{l}\text { Spot } 42 \\
\text { core }\end{array}$ & $\begin{array}{l}\text { Spot } 43 \\
\text { core }\end{array}$ & $\begin{array}{l}\text { Spot } 44 \\
\text { core }\end{array}$ & $\begin{array}{l}\text { Spot } 45 \\
\text { core }\end{array}$ & $\begin{array}{l}\text { Spot } 46 \\
\text { core }\end{array}$ & \begin{tabular}{|l} 
Spot 47 \\
rim
\end{tabular} & $\begin{array}{l}\text { Spot } 48 \\
\text { rim }\end{array}$ & $\begin{array}{l}\text { Spot } 49 \\
\text { rim }\end{array}$ & $\begin{array}{l}\text { Spot } 50 \\
\text { core }\end{array}$ & $\begin{array}{l}\text { Spot } 51 \\
\text { core }\end{array}$ & $\begin{array}{l}\text { Spot } 52 \\
\text { core }\end{array}$ & $\begin{array}{l}\text { Spot } 53 \\
\text { core }\end{array}$ & $\begin{array}{l}\begin{array}{l}\text { Spot } 54 \\
\text { core }\end{array} \\
\end{array}$ & $\begin{array}{l}\text { Spot } 55 \\
\text { core }\end{array}$ & $\begin{array}{l}\text { Spot } 56 \\
\text { core }\end{array}$ & $\begin{array}{l}\begin{array}{l}\text { Spot } 57 \\
\text { core }\end{array} \\
\end{array}$ & $\begin{array}{l}\text { Spot } 58 \\
\text { core }\end{array}$ & $\begin{array}{l}\text { Spot } 59 \\
\text { core }\end{array}$ & $\begin{array}{l}\text { Spot } 60 \\
\text { core }\end{array}$ & $\begin{array}{l}\text { Spot } 61 \\
\text { core }\end{array}$ & \\
\hline
\end{tabular}

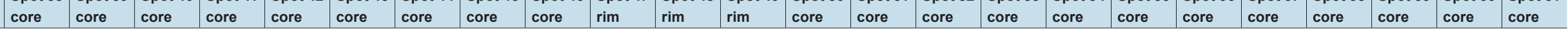
Major elements (wt\%)

\begin{tabular}{|c|c|c|c|c|c|c|c|c|c|c|c|c|c|c|c|c|c|c|c|c|c|c|c|c|}
\hline $\mathrm{SiO}_{2}$ & 0.00 & 0.10 & 0.10 & 0.13 & 0.12 & 0.19 & 0.00 & 0.00 & 0.10 & 0.11 & 0.13 & 0.10 & 0.00 & 0.10 & 0.11 & 0.00 & 0.00 & 0.00 & 0.00 & 0.00 & 0.00 & 0.00 & 0.00 & -0.03 \\
\hline $\mathrm{TiO}_{2}$ & 0.23 & 0.27 & 0.26 & 0.22 & 0.52 & 0.31 & 0.25 & 0.26 & 0.24 & 0.36 & 0.39 & 0.46 & 0.33 & 0.36 & 0.36 & 0.44 & 0.41 & 0.49 & 0.29 & 0.30 & 0.31 & 0.13 & 0.16 & 0.26 \\
\hline $\mathrm{Al}_{2} \mathrm{O}_{3}$ & 18.7 & 18.6 & 18.7 & 14.2 & 14.6 & 15.0 & 19.3 & 19.2 & 19.0 & 11.4 & 10.5 & 11.8 & 17.7 & 18.7 & 18.4 & 16.9 & 16.4 & 16.2 & 18.8 & 18.9 & 18.6 & 13.8 & 11.2 & 16.6 \\
\hline $\mathrm{eOt}$ & 30.6 & 30.5 & 31.0 & 29.6 & 34.8 & 30.4 & 30.1 & 30.0 & 30.0 & 32.3 & 32.6 & 32.6 & 30.0 & 30.4 & 31.0 & 33.3 & 33.0 & 33.1 & 30.3 & 30.4 & 30.6 & 28.2 & 28.5 & 29.8 \\
\hline $\lg 0$ & 6.77 & 6.69 & 6.57 & 4.60 & 5.13 & 3.77 & 7.08 & 7.12 & 7.06 & 4.68 & 4.38 & 4.59 & 6.02 & 6.31 & 6.28 & 5.89 & 5.77 & 5.76 & 6.85 & 6.92 & 6.79 & 5.54 & 5.34 & 6.32 \\
\hline $\mathrm{Cr}_{2} \mathrm{O}_{3}$ & 41.2 & 41.2 & 41.4 & 47.7 & 42.1 & 46.7 & 41.8 & 41.7 & 41.7 & 48.7 & 49.3 & 48.2 & 43.6 & 42.2 & 42.2 & 41.5 & 42.5 & 42.4 & 41.8 & 42.0 & 42.0 & 49.5 & 52.4 & 45.1 \\
\hline $\mathrm{V}_{2} \mathrm{O}_{3}$ & 0.33 & 0.22 & 0.31 & 0.37 & 0.38 & 0.42 & 0.29 & 0.31 & 0.30 & 0.35 & 0.39 & 0.37 & 0.33 & 0.28 & 0.35 & 0.32 & 0.34 & 0.39 & 0.29 & 0.29 & 0.30 & 0.38 & 0.32 & 0.32 \\
\hline $\mathrm{NiO}$ & 0.23 & 0.29 & 0.21 & 0.19 & 0.26 & 0.21 & 0.22 & 0.17 & 0.20 & 0.21 & 0.21 & 0.25 & 0.24 & 0.24 & 0.22 & 0.28 & 0.23 & 0.21 & 0.25 & 0.23 & 0.23 & 0.19 & 0.14 & 0.21 \\
\hline $\mathrm{Na}_{2} \mathrm{O}$ & 0.14 & 0.20 & 0.22 & 0.18 & 0.23 & 0.29 & 0.16 & 0.18 & 0.20 & 0.15 & 0.19 & 0.14 & 0.23 & 0.15 & 0.22 & 0.16 & 0.22 & 0.00 & 0.18 & 0.15 & 0.16 & 0.18 & 0.19 & 0.16 \\
\hline Total & 98.2 & 98.1 & 98.8 & 97.1 & 98.1 & 97.2 & 99.1 & 98.9 & 98.9 & 98.2 & 98.1 & 98.5 & 98.5 & 98.7 & 99.2 & 98.8 & 98.8 & 98.6 & 98.7 & 99.2 & 98.9 & 97.9 & 98.3 & 98.6 \\
\hline
\end{tabular}

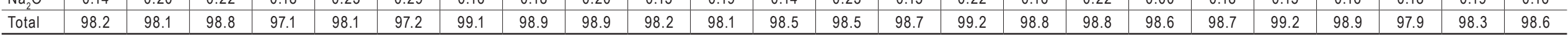


TABLE 2. Chromite mineral chemistry from the Troia-Pedra Branca metachromitite. (continued)

\begin{tabular}{|l|l|l|l|l|l|l|l|l|l|l|l|l|l|l|l|l|l|l|l|l|l|l|l|l|l} 
Spot 38 & Spot 39 & Spot 40 & Spot 41 & Spot 42 & Spot 43 & Spot 44 & Spot 45 & Spot 46 & Spot 47 & Spot 48 & Spot 49 & Spot 50 & Spot 51 & Spot 52 & Spot 53 & Spot 54 & Spot 55 & Spot 56 & Spot 57 & Spot 58 & Spot 59 & Spot 60 & Spot 61
\end{tabular}

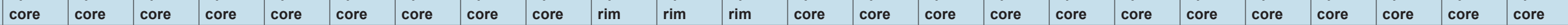
a.p.f.u. (4 oxygen)

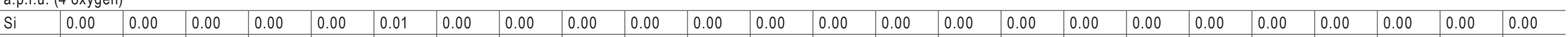

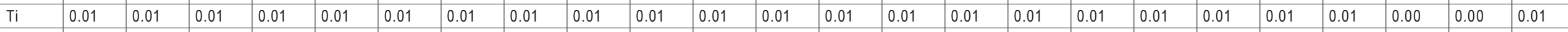

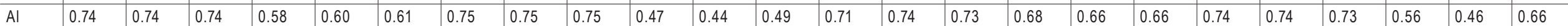

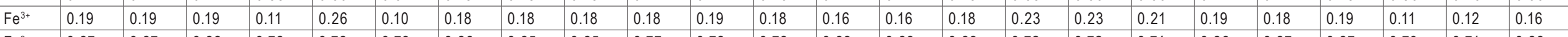

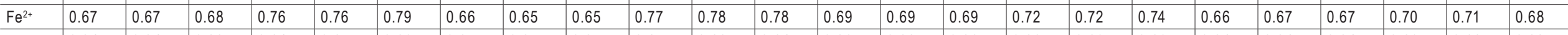

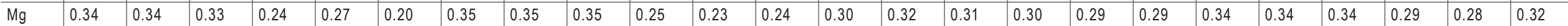

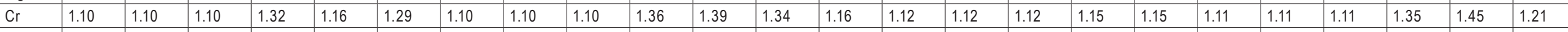

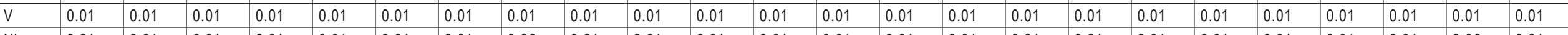

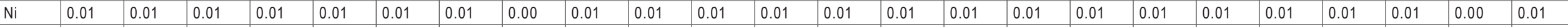

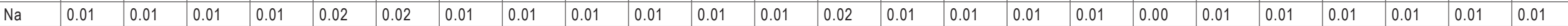

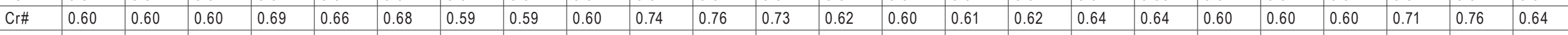

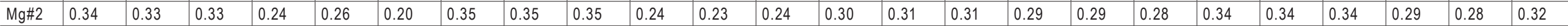

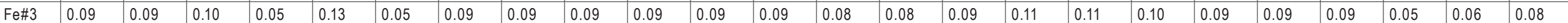

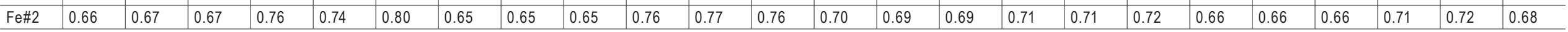

$\left(\mathrm{FeOt}=\right.$ measured total iron as $\left.\mathrm{Fe}^{2+}\right)\left(\mathrm{Fe}^{2+}\right.$ and $\mathrm{Fe}^{3+}$ were calculated from stichiometry) (a.p.f.u. = atoms per formula unit)

TABLE 3. Olivine mineral chemistry from the Troia-Pedra Branca metadunite.

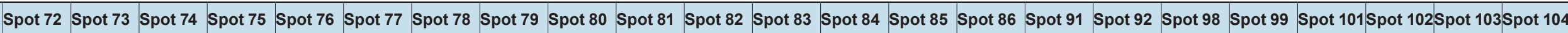
Major elements $(w t \%)$

\begin{tabular}{|c|c|c|c|c|c|c|c|c|c|c|c|c|c|c|c|c|c|c|c|c|c|c|c|}
\hline $\mathrm{SiO}_{2}$ & 40.29 & 40.22 & 40.22 & 40.4 & 40.31 & 40.19 & 40.34 & 40.21 & 40.22 & 40.27 & 40.35 & 40.14 & 40.3 & 40.27 & 40.08 & 40.17 & 40.23 & 40.32 & 40.42 & 40.02 & 40.03 & 39.98 & 40.12 \\
\hline $\mathrm{FeOt}$ & 14.53 & 14.55 & 14.55 & 14.58 & 14.53 & 14.39 & 14.58 & 14.48 & 14.57 & 14.57 & 14.64 & 14.7 & 14.43 & 14.32 & 14.53 & 14.3 & 14.32 & 14.54 & 14.59 & 14.67 & 14.44 & 14.52 & 14.65 \\
\hline $\mathrm{MgO}$ & 44.64 & 44.49 & 44.57 & 44.57 & 44.37 & 44.61 & 44.64 & 44.52 & 44.59 & 44.58 & 44.54 & 44.37 & 44.54 & 44.64 & 44.66 & 44.34 & 44.48 & 44.58 & 44.56 & 44.36 & 44.46 & 44.48 & 44.4 \\
\hline $\mathrm{NiO}$ & 0.41 & 0.4 & 0.37 & 0.41 & 0.39 & 0.34 & 0.37 & 0.36 & 0.39 & 0.4 & 0.36 & 0.4 & 0.42 & 0.38 & 0.38 & 0.34 & 0.35 & 0.37 & 0.37 & 0.41 & 0.41 & 0.42 & 0.38 \\
\hline Total & 99.86 & 99.65 & 99.72 & 99.96 & 99.6 & 99.54 & 99.93 & 99.56 & 99.76 & 99.82 & 99.89 & 99.61 & 99.69 & 99.6 & 99.65 & 99.15 & 99.38 & 99.81 & 99.94 & 99.47 & 99.33 & 99.41 & 99.56 \\
\hline \multicolumn{24}{|c|}{ a.p.f.u. (4 oxygen) } \\
\hline $\mathrm{Si}$ & 1.00 & 1.00 & 1.00 & 1.01 & 1.01 & 1.00 & 1.00 & 1.00 & 1.00 & 1.00 & 1.00 & 1.00 & 1.01 & 1.00 & 1.00 & 1.01 & 1.01 & 1.00 & 1.01 & 1.00 & 1.00 & 1.00 & 1.00 \\
\hline $\mathrm{Fe}^{2+}$ & 0.31 & 0.31 & 0.31 & 0.31 & 0.31 & 0.30 & 0.31 & 0.31 & 0.31 & 0.31 & 0.31 & 0.31 & 0.30 & 0.30 & 0.31 & 0.30 & 0.30 & 0.31 & 0.31 & 0.31 & 0.31 & 0.31 & 0.31 \\
\hline $\mathrm{Mg}$ & 1.68 & 1.68 & 1.68 & 1.67 & 1.67 & 1.68 & 1.68 & 1.68 & 1.68 & 1.68 & 1.67 & 1.67 & 1.68 & 1.68 & 1.68 & 1.68 & 1.68 & 1.68 & 1.67 & 1.68 & 1.68 & 1.68 & 1.68 \\
\hline $\mathrm{Ni}$ & 0.01 & 0.01 & 0.01 & 0.01 & 0.01 & 0.01 & 0.01 & 0.01 & 0.01 & 0.01 & 0.01 & 0.01 & 0.01 & 0.01 & 0.01 & 0.01 & 0.01 & 0.01 & 0.01 & 0.01 & 0.01 & 0.01 & 0.01 \\
\hline Total & 3.00 & 3.00 & 3.00 & 2.99 & 2.99 & 3.00 & 3.00 & 3.00 & 3.00 & 3.00 & 3.00 & 3.00 & 2.99 & 3.00 & 3.00 & 2.99 & 2.99 & 3.00 & 2.99 & 3.00 & 3.00 & 3.00 & 3.00 \\
\hline Fo & 0.85 & 0.84 & 0.85 & 0.84 & 0.84 & 0.85 & 0.85 & 0.85 & 0.85 & 0.85 & 0.84 & 0.84 & 0.85 & 0.85 & 0.85 & 0.85 & 0.85 & 0.85 & 0.84 & 0.84 & 0.85 & 0.85 & 0.84 \\
\hline
\end{tabular}

$\left(\mathrm{FeOt}=\right.$ total iron as $\left.\mathrm{Fe}^{2+}\right) \quad$ (a.p.f.u. $=$ atoms per formule unit) $\quad\left(\right.$ Forsterite content $\left.=\mathrm{Fo}=\mathrm{Mg} /\left(\mathrm{Mg}+\mathrm{Fe}^{2+}\right)\right)$ 


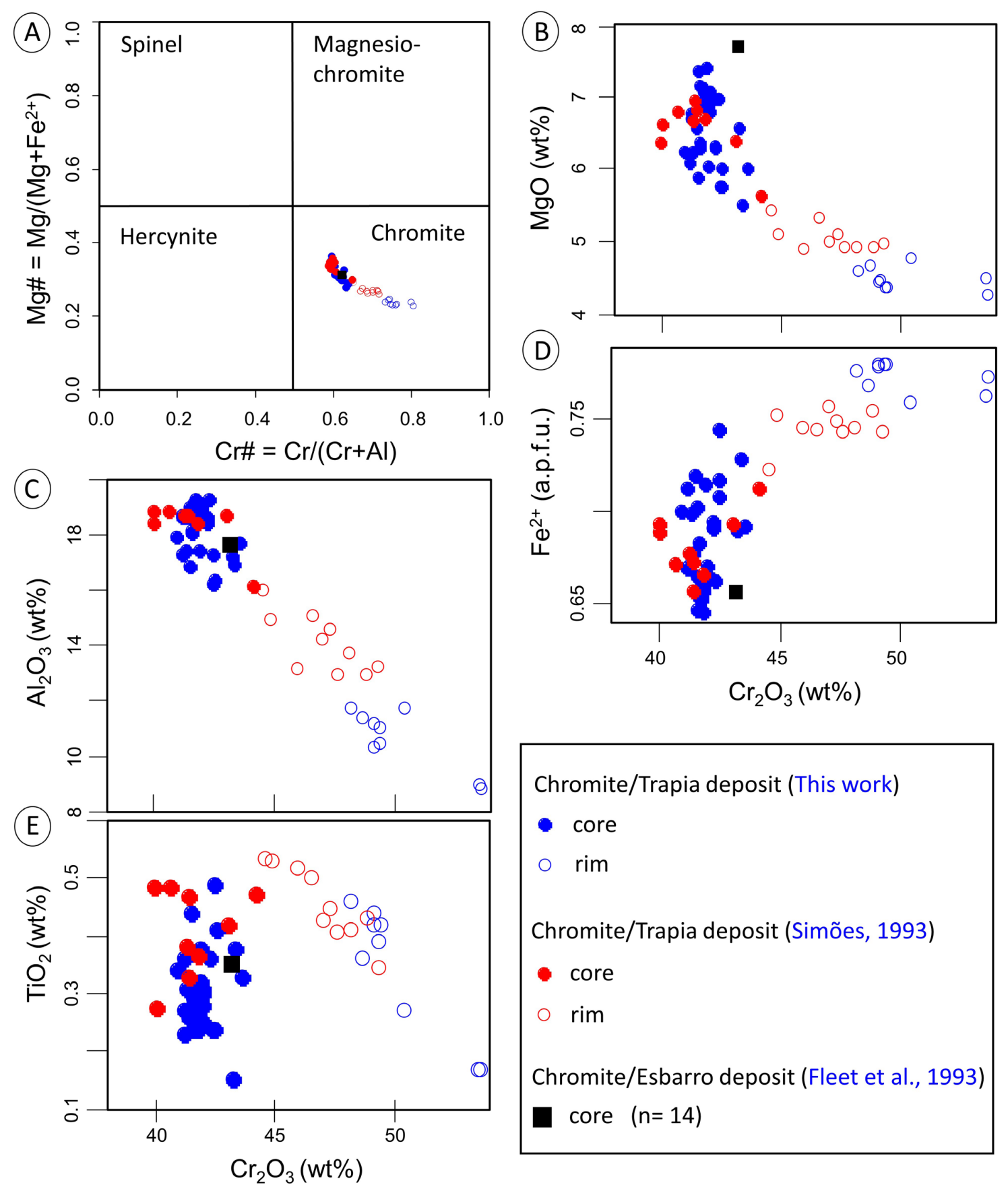

FIGURE 13. Troia-Pedra Branca chromite mineral chemistry. (A) $\mathrm{C} \#=\mathrm{Cr} /(\mathrm{Cr}+\mathrm{Al})$ vs. $\mathrm{Mg} \#=\mathrm{Mg} /\left(\mathrm{Mg}+\mathrm{Fe}^{2+}\right)$ (atomic proportion) diagram with the mineral classification field from Schulze (2001). (B) $\mathrm{MgO}$ (wt.\%) vs. $\mathrm{Cr}_{2} \mathrm{O}_{3}$ (wt.\%). (C) $\mathrm{Al}_{2} \mathrm{O}_{3}$ (wt.\%) vs. $\mathrm{Cr}_{2} \mathrm{O}_{3}$ (wt.\%). (D) $\mathrm{Fe}^{2+}$ (a.p.f.u.) vs. $\mathrm{Cr}_{2} \mathrm{O}_{3}$ (wt.\%). (E) $\mathrm{TiO}_{2}$ (wt.\%) vs. $\mathrm{Cr}_{2} \mathrm{O}_{3}$ (wt.\%). 
TABLE 4. U-Pb SHRIMP zircon data.

\begin{tabular}{|c|c|c|c|c|c|c|c|c|c|c|c|c|c|c|}
\hline Spot & U (ppm) & $\begin{array}{l}\text { Th } \\
\text { (ppm) }\end{array}$ & $\begin{array}{l}{ }^{232} \mathrm{Th} / \\
{ }^{238} \mathrm{U}\end{array}$ & $\begin{array}{l}\begin{array}{l}206 \mathrm{~Pb}^{*} \\
(\%)\end{array}\end{array}$ & $\begin{array}{l}{ }^{207} \mathrm{~Pb} / \\
{ }^{235} \mathrm{U}\end{array}$ & "\% err" & $\begin{array}{l}{ }^{206} \mathrm{~Pb} / \\
{ }^{238} \mathrm{U}\end{array}$ & "\% err" & $\begin{array}{l}\text { err. } \\
\text { Corr. }\end{array}$ & $\begin{array}{l}{ }^{206} \mathrm{~Pb} / \\
{ }^{238} \mathrm{U} \text { age }\end{array}$ & $\begin{array}{l}\text { err. } \\
(1 \sigma)\end{array}$ & $\begin{array}{l}{ }^{207} \mathrm{~Pb} / \\
{ }^{206} \mathrm{~Pb} \text { age }\end{array}$ & $\begin{array}{l}\text { err. } \\
(1 \sigma)\end{array}$ & $\begin{array}{l}\text { Conc. } \\
(\%)\end{array}$ \\
\hline JN88-10 & 79 & 16 & 0.21 & 0.87 & 2.43 & 4.69 & 0.19 & 2.74 & 0.58 & 1095 & 28 & 1534 & 72 & 60 \\
\hline JN88-9 & 97 & 20 & 0.22 & 0.84 & 2.34 & 4.32 & 0.18 & 2.69 & 0.62 & 1077 & 27 & 1496 & 64 & 61 \\
\hline JN88-4 & 114 & 26 & 0.23 & 0.95 & 1.83 & 4.84 & 0.16 & 2.72 & 0.56 & 970 & 24 & 1242 & 78 & 72 \\
\hline JN88-7 & 138 & 32 & 0.24 & 0.74 & 1.32 & 4.74 & 0.13 & 2.63 & 0.56 & 796 & 20 & 1003 & 80 & 74 \\
\hline JN88-12 & 75 & 18 & 0.25 & 0.21 & 4.42 & 3.18 & 0.27 & 2.71 & 0.85 & 1549 & 37 & 1928 & 30 & 76 \\
\hline JN88-13 & 80 & 18 & 0.24 & 0.65 & 3.85 & 3.98 & 0.25 & 2.71 & 0.68 & 1457 & 35 & 1802 & 53 & 76 \\
\hline JN88-8 & 73 & 21 & 0.30 & 0.20 & 5.43 & 3.07 & 0.33 & 2.69 & 0.88 & 1822 & 43 & 1965 & 26 & 92 \\
\hline JN88-1 & 79 & 26 & 0.35 & 0.63 & 5.39 & 3.31 & 0.33 & 2.75 & 0.83 & 1848 & 44 & 1923 & 33 & 96 \\
\hline JN88-11 & 83 & 33 & 0.41 & 0.30 & 5.90 & 3.12 & 0.35 & 2.69 & 0.86 & 1937 & 45 & 1987 & 28 & 97 \\
\hline JN88-14 & 72 & 24 & 0.34 & 0.09 & 6.55 & 3.25 & 0.37 & 2.73 & 0.84 & 2040 & 48 & 2065 & 31 & 99 \\
\hline JN88-3 & 145 & 65 & 0.46 & 0.09 & 6.69 & 2.72 & 0.38 & 2.56 & 0.94 & 2076 & 46 & 2067 & 16 & 100 \\
\hline JN88-6 & 67 & 23 & 0.36 & 0.51 & 6.71 & 3.40 & 0.38 & 2.74 & 0.81 & 2088 & 49 & 2061 & 36 & 101 \\
\hline JN88-16 & 73 & 22 & 0.32 & 0.00 & 6.48 & 3.26 & 0.38 & 2.69 & 0.83 & 2094 & 48 & 1992 & 33 & 105 \\
\hline
\end{tabular}

$\left({ }^{206} \mathrm{~Pb}^{*}=\right.$ common lead $)$

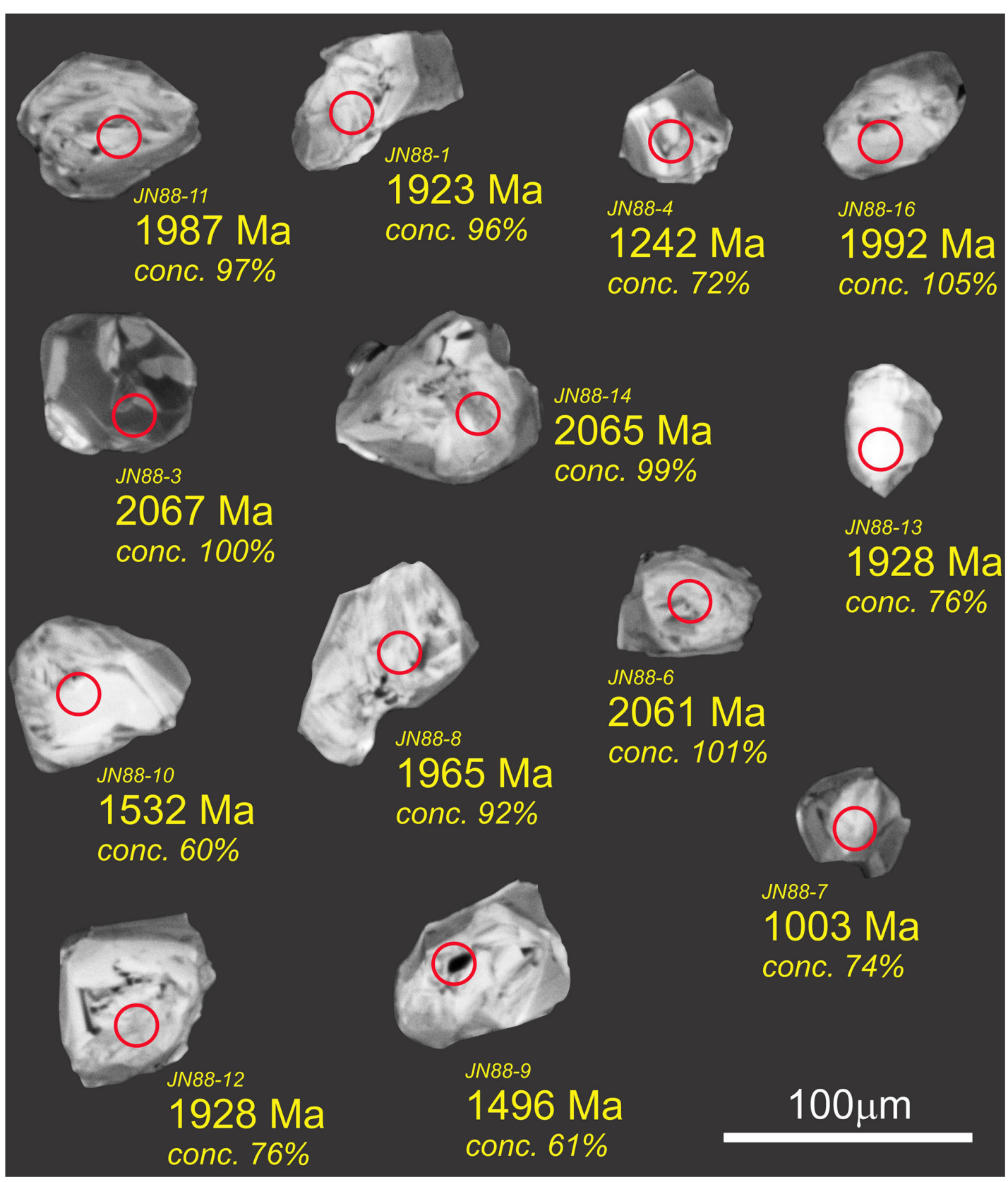

FIGURE 14. Cathodoluminescence images for the analysed zircon grains of the Troia-Pedra Branca metachromitite. Red circles indicate the SHRIMP spots and respective zircon ages are ${ }^{207} \mathrm{~Pb} / 206 \mathrm{~Pb}$. All U- $\mathrm{Pb}$ results are shown in Table 4, and conc. $=$ concordance. 


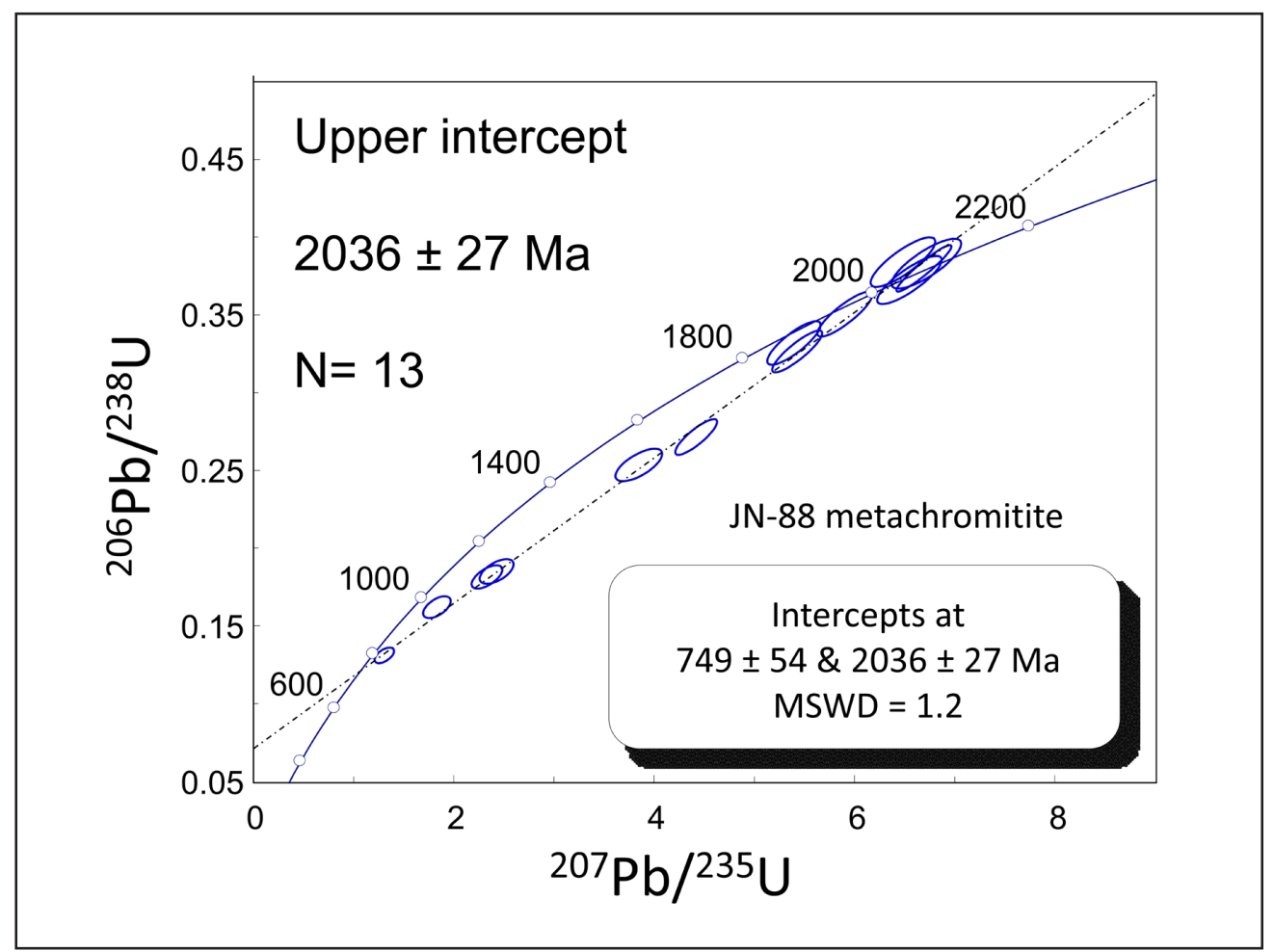

FIGURE 15. Concordia diagram for U-Pb (SHRIMP) zircon data of the Troia-Pedra Branca metachromitite, showing all zircons within the regression (discordia) line. All plots are $2 \sigma$.

Fleet et al. (1993) as a Cr-rich clinochlore variety, formally known as "Kammererite".

The metamorphic chlorite-serpentine matrix of the metachromitites hosts the ore minerals (PGM) of the TroiaPedra Branca PGE deposit. The PGM occur within the chlorite-serpentine matrix along the chlorite cleavage and at the contact between serpentine and chlorite minerals (Fig. $8 \mathrm{C}$ ). They are also found as well-crystallized crystals at the edge of deformed (subrounded) chromite grains (Fig. 8 B). These textural relationships suggest that the PGM have been recrystallized, and probably, locally remobilized. The presence of secondary PGM associated with low-grade metamorphism of chromitites is commonly described in the literature (e.g., Ferrario and Garuti 1988, Zaccarini et al. 2004, Prichard et al. 2008, Tolstykn et al. 2009). According to Zaccarini et al. (2004), secondary (metamorphic) PGM may form in metachromitites during metamorphism, involving both in situ alteration of primary PGM and direct deposition of PGE from hydrous solutions. However, PGEs are not added to the metachromitites from an external source, and they are likely formed by alteration of intercumulus primary magmatic PGM and/or PGE-rich sulfides, originally located interstitially to the grains of chromites (Sattari et al. 2002, Zaccarini et al. 2004). This is likely the case of the Troia-Pedra Branca PGE mineralization; early magmatic PGM were dominantly present as an interstitial phase. The lack of PGM inclusions in the study chromites supports this hypothesis. Thus, we suggest that a low-grade metamorphic event has remobilised PGE from PGE-bearing minerals and/or recrystallized igneous PGM, forming secondary PGM in the metachromitite matrix (Fig. 8 A, B and C). However, after several drill core descriptions and geochemical interpretations of the
Troia-Pedra Branca deposit, there is no doubt that PGE mineralization is controlled by magmatic precipitation along with the chromitite seams, and no PGE have been remobilized from the metachromitites to precipitate elsewhere along the shear zones (H.R. Barrueto, oral presentation). The age of the metamorphic event that affected the chromitites and the associated PGE mineralization is likely to be $749 \mathrm{Ma}$, as indicated by radiogenic $\mathrm{Pb}$ loss (lower intercept $=749 \pm$ $54 \mathrm{Ma}$ ) in the analyzed zircon grains of the metachromitite sample (Fig. 15). Petrographic analyses have identified xenotime rims surrounding hydrothermally altered zircon grains in the matrix of the metachromitites, which support our interpretation of the $749 \mathrm{Ma}$ age (Fig. $8 \mathrm{E}$ ). The alteration of zircon by hydrothermal fluids forming xenotime has long been described in the literature (e.g., Spandler et al. 2004, Geisler et al. 2007).

\subsection{Tectonic setting of the Troia-Pedra Branca complex}

The whole-rock geochemical data show that the metagabbros of the Troia-Pedra Branca complex have clear affinity to calc-alkaline basaltic series (Fig. 11), which is compatible with their high content of magmatic hornblende, and to minor biotite in the most evolved gabbro-diorite facies. The presence of hornblendites (cumulate) in the study area (Fig. 3) suggests that amphiboles played an important role in magmatic differentiation, which is typical of water-bearing arc magmatism (e.g., Arculus 1994, Davidson et al. 2007, Larocque and Canil 2010). The study metagabbros are hornblende-rich and show a trend for correlation in the $\mathrm{Sr} / \mathrm{Y}$ versus $\mathrm{Y}$ diagram, which is typical of deep fractionation of hydrous basalt magma 


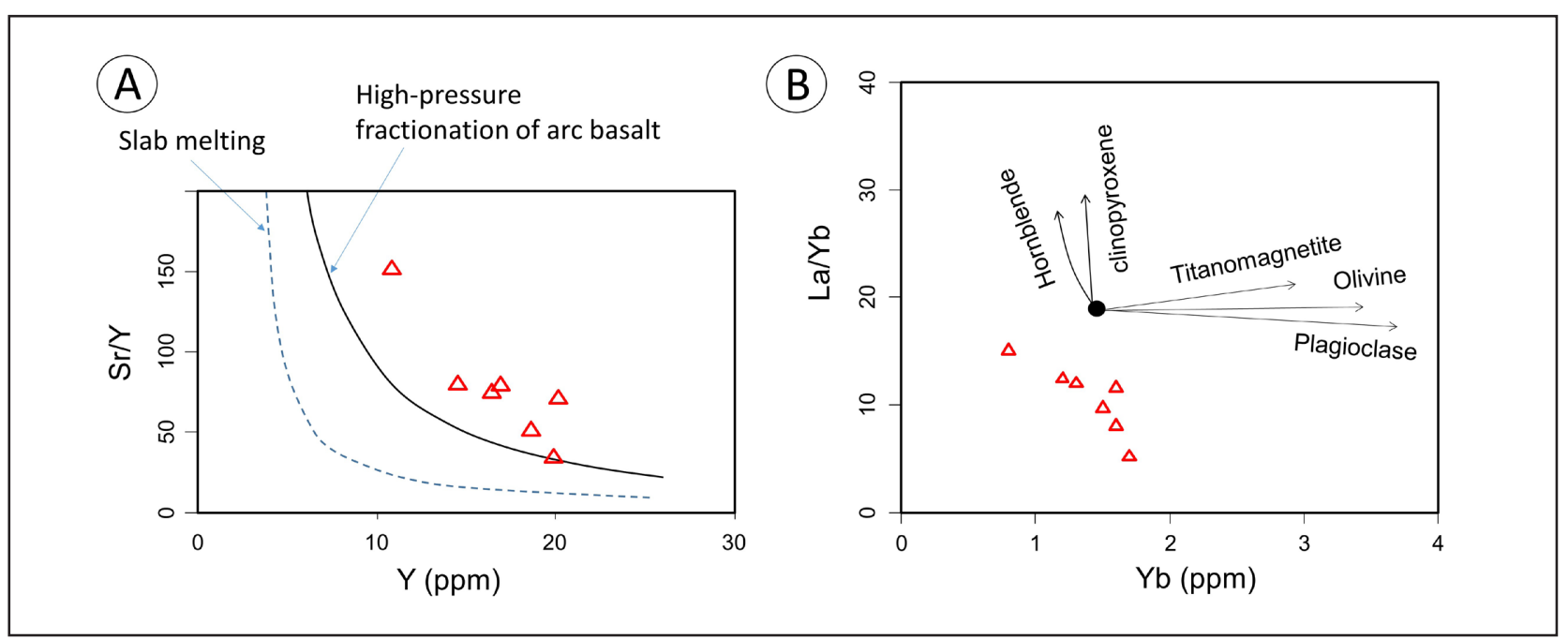

FIGURE 16. Plotting of the Troia-Pedra Branca metagabbros in the (A) Sr/Y vs. Y with the trends of high-pressure fractionation of arc basalt and slab melt from Macpherson et al. (2006). (B) La/Yb vs. Yb diagram with differentiation paths resulting from fractionation of various minerals (after Castillo et al. 1999).

(Fig. 16 A). According to Macpherson et al. (2006), fractionation of arc basalts magmas may be dominated by hornblende $( \pm$ garnet) fractional crystallization, as the hydrous mantle melts are located at the base of the crust. The study metagabbro samples show a pronounced trend in the $\mathrm{Yb}$ versus $\mathrm{La} / \mathrm{Yb}$, which is compatible with hornblende (and/or clinopyroxene) fractionation (Fig. $16 \mathrm{~B}$ ). In addition, the negative correlation of $\mathrm{Yb}$ and $\mathrm{Y}$ versus $\mathrm{MgO}$ is also suggestive of hornblende fractional crystallization (Fig. 10).

The metagabbros show slight enrichment in LILE and depletion in some HFSE (e.g., Nb, Zr, and Ti) (Fig. $12 \mathrm{~A}$ ), as well as enrichment in LREE (Fig. 12 B). In the chrondrite-normalized diagram, the study metagabbros show a more similar pattern to enriched mid-ocean basalts (E-MORB) and ocean island basalts (OIB) than to typical normal (tholeiite) MORB (Fig. 12 $B)$. These characteristics, together with the observed negative anomalies of $\mathrm{Nb}$ and $\mathrm{Ti}$ (Fig. $12 \mathrm{~A}$ ), are generally considered as typical features of magmas generated in subduction zones (Pearce 1982, Wilson 1989, Gao et al. 2007).

Geochemical discrimination diagrams for inferring tectonic setting also show that the geochemical signatures of the TroiaPedra Branca metagabbros are closely related to a subduction setting (Fig. $17 \mathrm{~A}$ and $\mathrm{B}$ ). On the $\mathrm{Th} / \mathrm{Yb}$ versus $\mathrm{Nb} / \mathrm{Yb}$ diagram, all samples of the study metagabbros plot above the MORBOIB array and follow the (subduction-related) volcanic arc array (Fig. 17 A). In this diagram, the study metagabbros show very similar characteristics to those of continental arc basalts (Fig. $17 \mathrm{~A}$ ). Therefore, the Th-Nb proxy suggests that the mantle source of the parental melts of the Troia-Pedra Branca metagabbros were metasomatized by the subduction of crustal materials (Fig. $17 \mathrm{~A}$ ). In addition, the Ti versus $\mathrm{Zr}$ diagram from Pearce (1982) shows that the metagabbros have a clear affinity to island arc basalts (Fig. $17 \mathrm{~B}$ ). According to Pearce (1982), magnetite is an early phase of crystallization in hydrous arc magmatism, hence the titanium ( $\mathrm{Ti}$ ) content does not reach high values of (low-water) within-plate basalts (Fig. $17 \mathrm{~B})$. In this diagram, the study metagabbros show similar $\mathrm{Ti}$ and $\mathrm{Zr}$ content to that of other Alaskan-type gabbroic intrusions worldwide, but lower contents when compared to the Norilsk mafic intrusions (Fig. 17 B).
In the AFM ternary diagram, the metagabbros plot mostly in the field of Alaskan-type gabbros, that partially overlaps the field for arc-related gabbros and diorites from Beard (1986) (Fig. 18). In this diagram, the metachromitites and metadunites show similar geochemical signatures to arc-related cumulates and arc-related ultramafic cumulates, respectively (Fig. 18).

The term "Alaskan-type complex" was defined by Irvine (1974) to classify many arc-related PGE-bearing maficultramafic intrusions of southern Alaska, which are similar to Paleozoic Uralian mafic-ultramafic magmatism (Far East Russia) (e.g., Batanova et al. 2005). In recent years, the "Alaskan-type" term has been widely used worldwide to refer to many mafic-ultramafic intrusions that have geochemical signatures compatible with a subduction-modified mantle source (e.g., Eyuboglu et al. 2010, Tian et al. 2011, Tseng et al. 2015, Yuan et al. 2017, Liu et al. 2021). For example, the Quetico intrusions, in the Archean Superior Province, Canada, comprise several Neoarchean (ca. 2690 Ma) maficultramafic plutons with arc-related geochemical signature and accompanying PGE mineralization that are similar to the Phanerozoic Alaskan-type complexes (Pettigrew and Hattori 2006). The lithologies of the Quetico intrusions are also similar to those of the Troia-Pedra Branca complex, with dunite, hornblendite, clinopyroxenite, gabbro and diorite (MacTavish 1999, Pettigrew and Hattori 2006). By comparison, the major elements from whole-rock samples of the Quetico intrusions on the AFM diagram show a similar compositional trend to that of the Troia-Pedra Branca mafic-ultramafic complex (Fig. 18).

\subsection{Interpretations of mineral geochemical data}

The $\mathrm{Cr}$-spinel (chromite) $\left[\left(\mathrm{Mg}^{2+}, \mathrm{Fe}^{2+}\right)\left(\mathrm{Cr}^{3+}, \mathrm{Al}^{3+}, \mathrm{Fe}^{3+}\right)_{2} \mathrm{O}_{4}\right]$ may present several variations on its major element contents, which might represent the chemical signature of particular tectonic settings (e.g. ophiolite complexes or stratiform intrusions) (e.g. Irvine 1967, Dick and Bullen 1984, Arai 1992, Stowe 1994, Barnes and Roeder 2001, Kamenetsky et al. 2001) and/or alteration by post-magmatic/ metamorphic processes (e.g. Spier and Ferreira Filho 2001, González Jiménez et al. 2009, Merlini et al. 2009, Grieco 

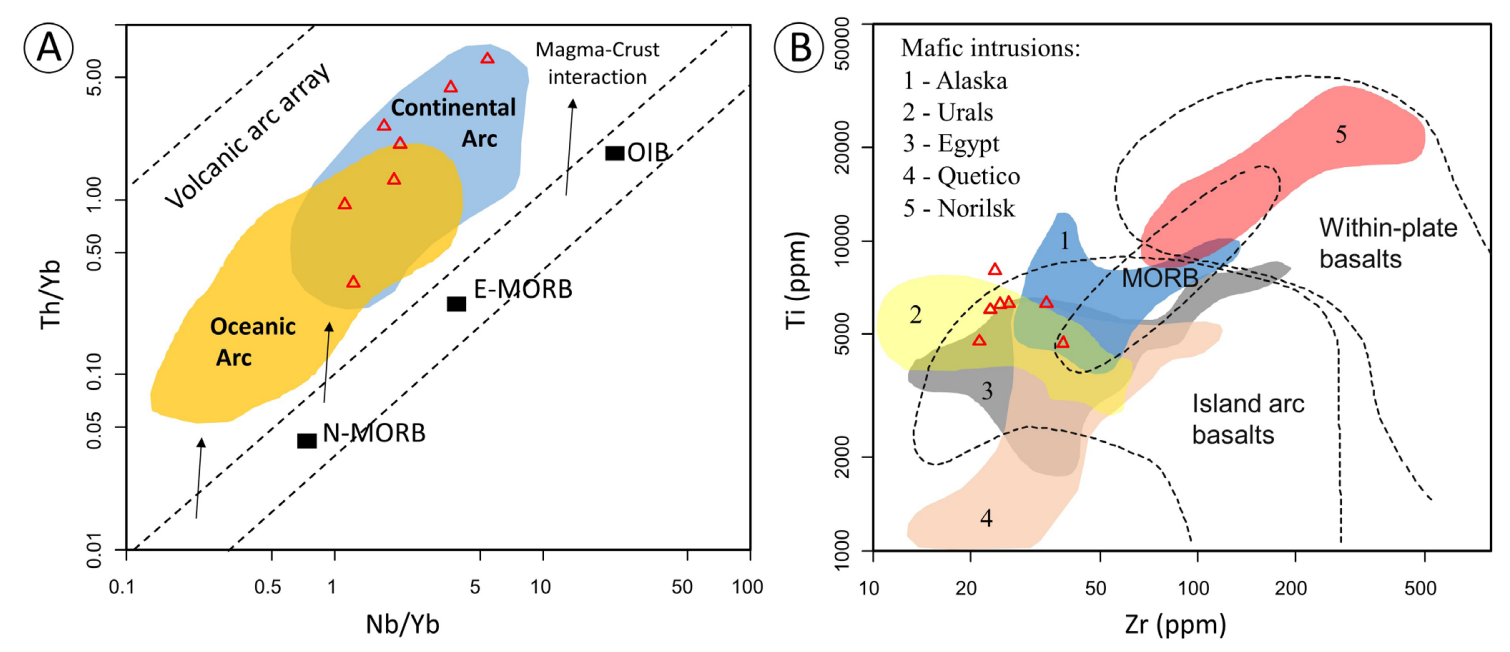

FIGURE 17. Tectonic discrimination diagrams for the investigated metagabbros from the Troia-Pedra Branca mafic-ultramafic complex. (A) Nb/Yb versus Th/Yb from Pearce (2008) showing the MORB-OIB array (shaded) of typical oceanic basalts. The fields for continental and oceanic arc basalts are from Pearce and Peate (1995). (B) Zr versus Ti from Pearce (1982). (N-MORB = normal mid-ocean ridge basalts, $\mathrm{E}-\mathrm{MORB}=$ enriched mid-ocean ridge basalts, OIB = ocean island basalts). Fields for Alaskan-type gabbroic intrusions are from 1- Southern Alaska (Himmelberg and Loney 1995), 2- Urals (Fershtater et al. 1999, Krause 2008), 3- Egypt (Azer et al. 2017, Abdallah et al. 2019), 4- Quetico (MacTavish 1999) and 5- Norilsk mafic intrusions (Sereda et al. 2020).

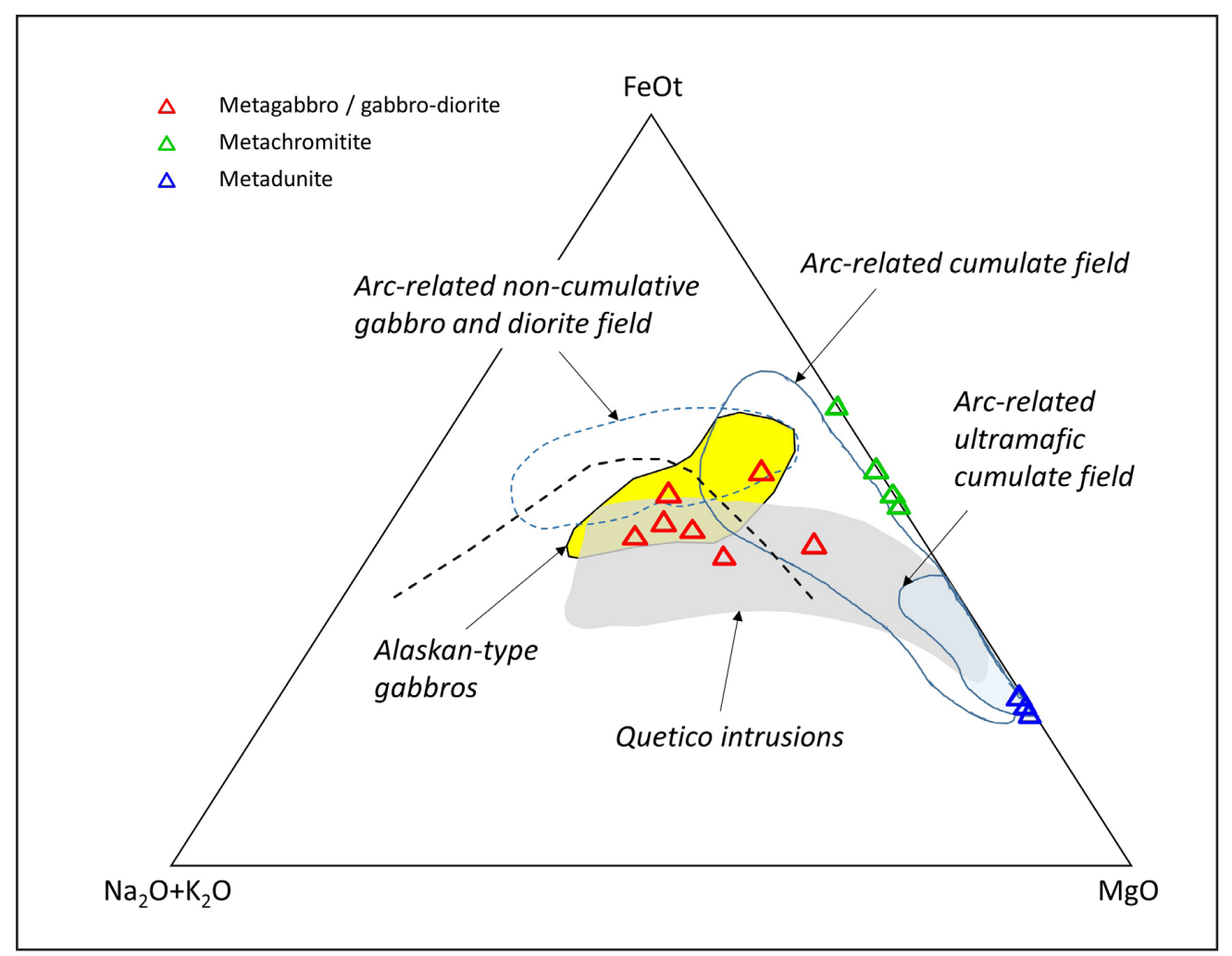

FIGURE 18. AFM diagram for the representative units of the Troia-Pedra Branca mafic-ultramafic complex. Fields for arc-related cumulate and arc-related non-cumulate ultramafic-mafic rocks are from Beard (1986). The field for the Alaskan-type gabbro is from Himmelberg and Loney (1995) and the field for the Quetico intrusions is from MacTavish (1999). 
and Merlini 2012, Mansur and Ferreira Filho 2017, Bhat et al. 2019, Vishal et al. 2020). The chromites from Troia-Pedra Branca metachromitites show chemical variations with depleted $\mathrm{Mg}$ and $\mathrm{Al}$ rims compared to their core content, suggesting alteration in post-magmatic/metamorphic processes (Fig. 13, Table 2). The effects of metamorphism in the Troia-Pedra Branca chromites have already been documented in previous works (Fleet et al. 1993, Simões 1993, Angeli et al. 2009). According to Fleet et al. (1993), loss of aluminum of the chromite rims was probably due to the formation of metamorphic $\mathrm{Cr}$-rich chlorite (Kammererite) in the metachromitite matrix. The Troia-Pedra Branca chromites were hydrothermally altered to iron-rich margins (ferritchromite) (Fig. 13 E, Table 2) (Fleet et al. 1993, Simões 1993, Angeli et al. 2009), which is a common feature on metamorphosed chromitites worldwide (e.g., Merlini et al. 2009, Bhat et al. 2019). However, the high-Al chromite cores (Fig. $13 \mathrm{C}$, Table 2) may still represent the original (igneous) chemical composition (Fleet et al. 1993, Simões 1993, Angeli et al. 2009). Previous interpretations have argued that the preserved chromite cores from the TroiaPedra Branca metachromitites are chemically similar to those of the stratiform complex (Simões 1993, Angeli et al. 2009). In fact, the Troia-Pedra Branca chromites do have similar chemistry to stratiform complexes when comparing to podiform (ophiolite) chromites (Fig. 19 A and B). However, they also have $\mathrm{Cr} \#$ and $\mathrm{Mg \#}$ numbers similar to Alaskan-type chromites (Fig. $19 \mathrm{~A}$ ). The study chromites have relatively lower Mg\# (from 0.28 to 0.36 in the cores) than chromites from ophiolite complexes, MORB and abyssal peridotites (Fig. 19 B). The field for stratiform igneous intrusions on the $\mathrm{Cr} \#$ versus $\mathrm{Mg \#}$ diagram (Fig. $19 \mathrm{~B}$ ), corresponds to the compilation data of four major stratiform complexes, Bushveld, Great Dyke, Stillwater and Muskox intrusions, according to Irvine (1967). These are intracratonic maficultramafic intrusions that generally have norite composition (orthopyroxene-bearing gabbros) (e.g., Hall and Hughes 1990, Hatton and Von Gruenewaldt 1990), which is distinct from those of clinopyroxene- and hornblende-bearing gabbros commonly present in subduction-related Alaskantype complexes (e.g., Himmelberg and Loney 1995, Batanova et al. 2005). Intracratonic noritic intrusions are probably derived from parental melts comparable to those of boninites (e.g., Srivastava 2008). The best examples of such intracratonic boninite-norite associations occur in the Bushveld (South Africa) and Sillwater (Montana, USA) complexes, in which orthopyroxene-bearing gabbros are commonly abundant (e.g., Hall and Hughes 1990, Hatton and Von Gruenewaldt 1990, Srivastava 2008). In this context, the Troia-Pedra Branca mafic-ultramafic complex comprises much more similar lithologies to those of the Alaskan-type, regarding the calc-alkaline hornblende-rich metagabbros and locally honblendites. The plot of the Troia-Pedra Branca chromite cores also show relatively lower $\mathrm{Cr} \#$ compared to boninites and stratiform intrusions (Fig. 19 B). Chromites from boninites and some stratiform intrusions have much higher $\mathrm{Mg \#}$ and $\mathrm{Cr} \#$ than Alaskan-type and the study Troia-Pedra Branca chromites (Fig. 19 B). Therefore, based on the $\mathrm{Cr} \#$ versus Mg\# diagram (Fig. $19 \mathrm{~B}$ ), we conclude that the chromites from the Troia-Pedra Branca complex are more similar to those of Alaskan-type complexes than to chromites from stratiform complexes. In the diagram of
$\mathrm{TiO}_{2}$ versus $\mathrm{Al}_{2} \mathrm{O}_{3}$, the Troia-Pedra Branca chromite cores plot partially in the field of Alaskan-type intrusions and also within the range of supra-subduction zone (SSZ) peridotites (Fig. $19 \mathrm{C}$ ). The study chromites also show strong affinity to supra-subduction zone peridotites on the $\mathrm{Fe}^{2+} / \mathrm{Fe}^{3+}$ versus $\mathrm{Al}_{2} \mathrm{O}_{3}$ diagram (Fig. $\left.19 \mathrm{D}\right)$. The calculated $\mathrm{Fe}^{3+}$ contents and associated $\mathrm{Fe \#}=\mathrm{Fe}^{3+} /\left(\mathrm{Fe}^{3+}+\mathrm{Cr}+\mathrm{Al}\right)$ values are relatively low, but still compatible with Alaskan-type complexes on the Fe\# versus Mg\# diagram (Fig. $19 \mathrm{E}$ ).

The forsterite content in olivines $\left(\mathrm{Fo}=\mathrm{Mg} /\left(\mathrm{Mg}+\mathrm{Fe}^{2+}\right)\right.$ from the Troia-Pedra Branca metadunites have very little variation ( $F o=0.84$ to 0.85 ) (Table 3 ), but they are within the range of values for Alaskan-type intrusion worldwide, such as those from Alaska and Neoproterozoic mafic-ultramafic intrusions in Egypt (Fig. 20 A). In comparison, we found that olivines in rocks from the Bushveld intracratonic intrusion show a wide variation in forsterite content, while the olivines from ophiolites have relatively high forsterite content (Fig. $20 \mathrm{~A}$ ). In the diagram of $\mathrm{NiO}$ versus forsterite content (Fo), olivines from the Troia-Pedra Branca metadunite show relatively higher $\mathrm{NiO}$ contents when compared to the Alaskan Global trend (Krause et al. 2007). Also, in the NiO versus Fo diagram, we can see that the Troia-Pedra Branca olivines plot in the lower limit of the mantle olivine array (Fig. 20 B). The olivine mantle array comprises a trend of olivines from mantle peridotite xenoliths in modern oceanic crust (Takahashi et al. 1987). Most of these mantle olivines have much higher $\mathrm{NiO}$ and Fo contents than Alaskan-type complexes (Fig. 20 B). Similarly, olivines from ophiolitic complexes also have much higher $\mathrm{NiO}$ and Fo contents than Alaskan-type complexes (Fig. 20 B). In addition, the Troia-Pedra Branca olivines plot partially within the field of the Dahanib intrusion in the $\mathrm{NiO}$ versus Fo diagram (Fig. 20 B). According to Khedr and Arai (2016), the Neoproterozoic Dahanib intrusion is a typical Alaskan-type complex derived from fractional crystallization of hydrous tholeiitic basaltic melts in a subduction setting.

\subsection{Evidence for a post-collisional setting}

The U-Pb SHRIMP zircon age of $2036 \pm 27 \mathrm{Ma}$ (Fig. 15) for the PGE-bearing metachromitites of the Troia-Pedra Branca complex set this mafic-ultramafic magmatism in the late tectonic evolutionary stages of the Rhyacian granite-greenstone terranes of the study area (Table 5). The evolution of Rhyacian terranes in the Troia Massif and Ceará Central Domain share many similarities with the 2.2-2.0 Ga Transamazonian/ Eburnean terranes of the surrounding cratonic domains (Fig. 1 A, B and C) (e.g., Fetter 1999, Martins et al. 2009, Costa et al. 2015, 2018). Many of these Transamazonian/Eburnean terranes of the South America and African counterpart (Fig. 1 A) are interpreted as island and/or continental arc sequences that evolved during 2.2-2.1 Ga accretionary tectonics, culminating at $2.1-2.0 \mathrm{Ga}$ in continental collision and regional metamorphism (Liégeois et al. 1991, Vanderhaeghe et al. 1998, Delor et al. 2003, Feybesse et al. 2006, McReath and Faraco 2006, Costa et al. 2011, Oliveira et al. 2011, Klein et al. 2012, Costa et al. 2015, 2018, McFarlane et al. 2019, Klein et al. 2020). For example, a crustal thickening event with high-grade metamorphism that generated two-mica granites in greenstone belts in the West Africa craton occurred between ca. 2092 and $2081 \mathrm{Ma}$ (McFarlane et al. 2019). Similarly, in the Troia Massif and surrounding Ceará Central Domain (Fig. 1 C), ages of ca. 


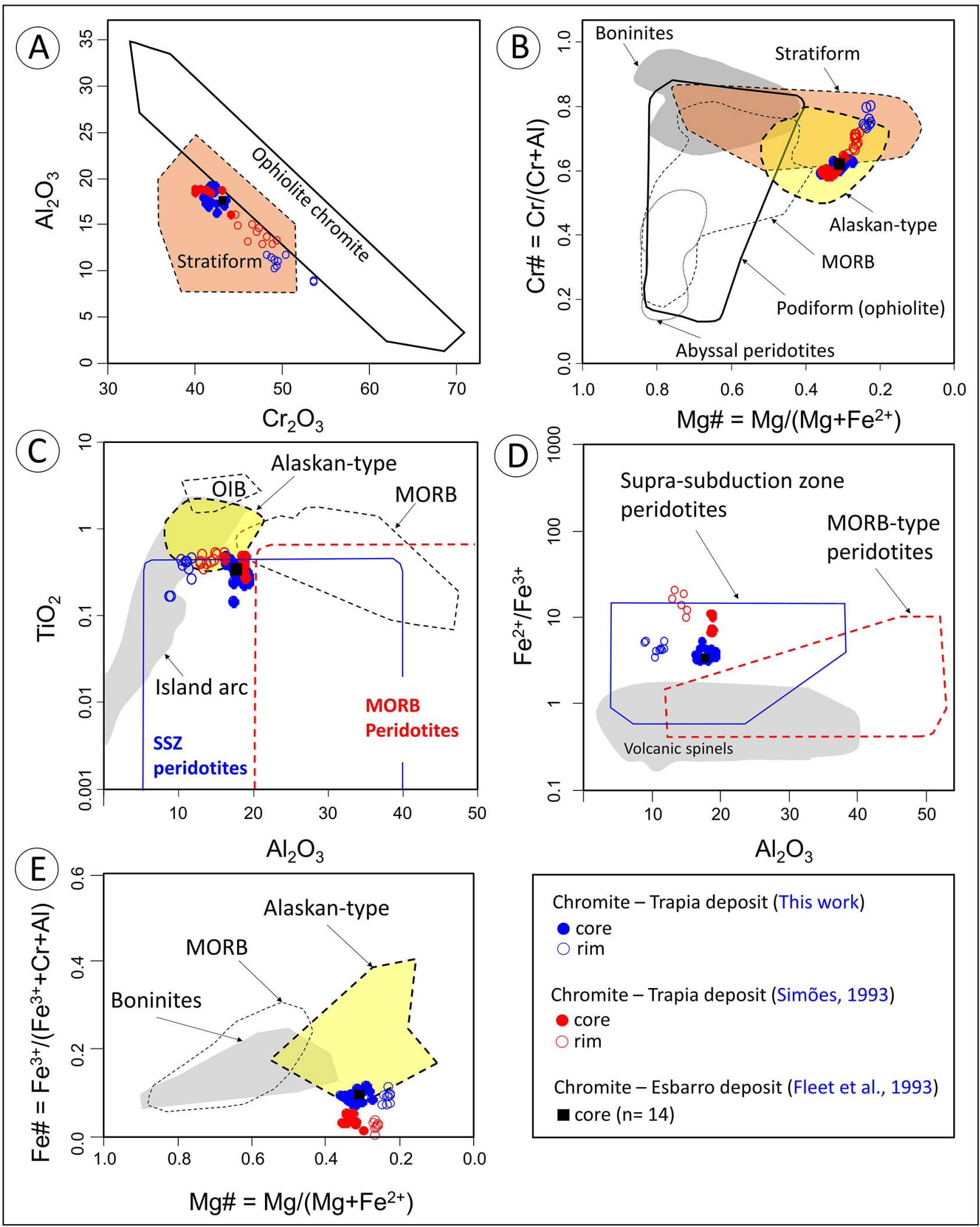

FIGURE 19. Chromite mineral chemistry of the Troia-Pedra Branca metachromitites. (A) Chemical composition of chromite on the $\mathrm{Al}_{2} \mathrm{O}_{3}$ vs. $\mathrm{Cr}_{2} \mathrm{O}_{3}$ diagram, compared with stratiform and podiform from Bonavia (1993). (B) $\mathrm{Cr} \#=\mathrm{Cr} /(\mathrm{Cr}+\mathrm{Al}) \mathrm{vs}$. $\mathrm{Mg} \#=\mathrm{Mg} / \mathrm{Mg} /\left(\mathrm{Mg}+\mathrm{Fe}{ }^{2+}\right)$ with classification fields for ophiolites (podiform) from Leblanc and Nicolas (1992), stratiform complexes from Irvine (1967), MORB and Boninite fields from Barnes and Roeder (2001), abyssal peridotite field from Dick and Bullen (1984), Alaskan-type field from Burns (1985) and Himmelberg and Loney (1995). (C) $\mathrm{TiO}_{2}$ vs. $\mathrm{Al}_{2} \mathrm{O}_{3}$. Field for ocean island basalts (OIB), mid-ocean-ridge basalts (MORB), island-arc series, supra-subduction zone (SSZ) peridotites and MORB peridotites are from Kamenetsky et al. (2001), and the Alaskantype complexes are from Burns (1985) and Himmelberg and Loney (1995). (D) $\mathrm{Fe}^{2+} / \mathrm{Fe}^{3+}$ versus $\mathrm{Al}_{2} \mathrm{O}_{3}$ diagram classification fields from Kamenetsky et al. (2001). (E) Fe\# $=\mathrm{Fe}^{3+} /\left(\mathrm{Fe}^{3+}+\mathrm{Cr}+\mathrm{Al}\right)$ vs. Mg\# diagram with MORB and Boninite fields from Barnes and Roeder (2001) and Alaskan-type field from Burns (1985) and Himmelberg and Loney (1995). 


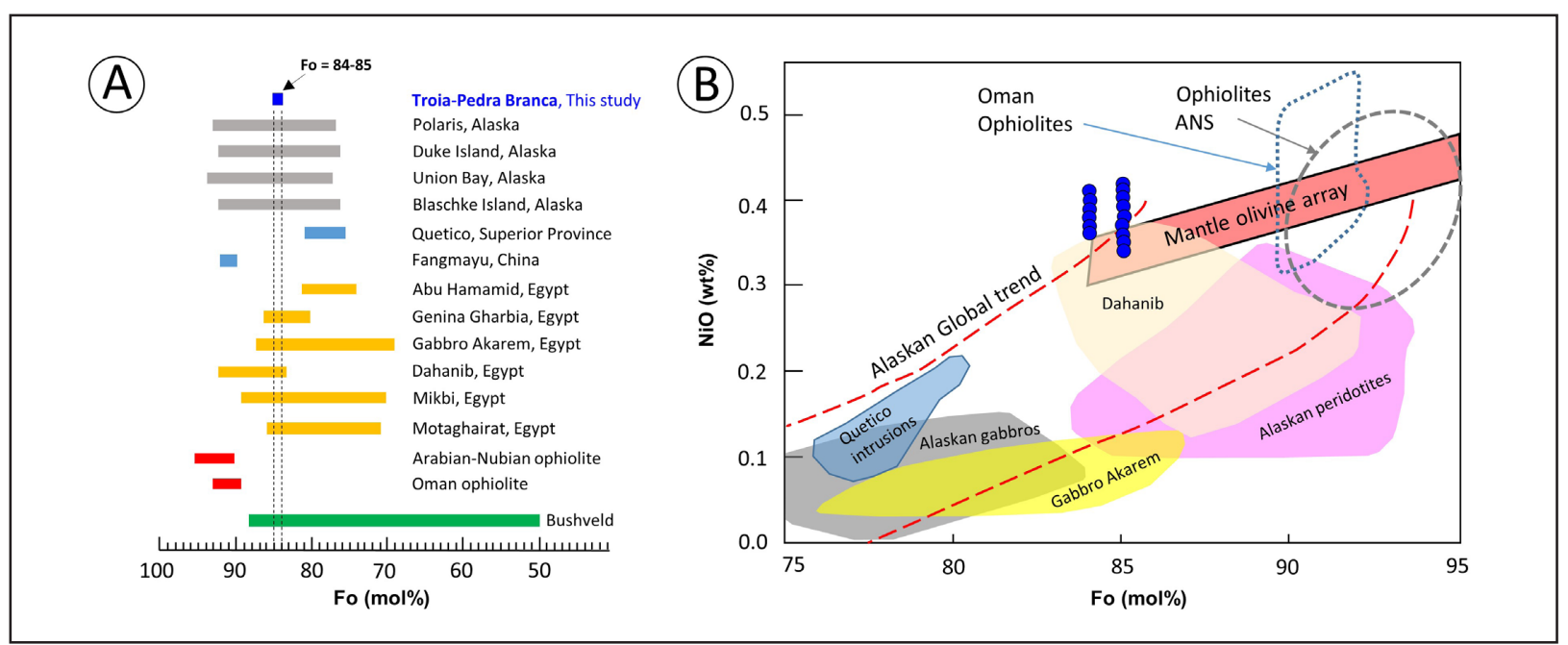

FIGURE 20. Olivine mineral chemistry of the Troia-Pedra Branca metadunites. (A) Comparative forsterite content (Fo) of the TroiaPedra Branca olivines with other mafic-ultramafic complexes worldwide. (B) Forsterite (Fo) content versus NiO of the TroiaPedra Branca olivines and fields for olivine composition in other mafic-ultramafic complexes worldwide. Data sources: Union Bay (Polaris) and Duke Island (Irvine 1967, 1974), Blashke Island (Himmelberg et al. 1986), Quetico intrusion (Pettigrew and Hattori 2006), Fangmayu intrusion (Han et al. 2021), Abu Hamamid (Farahat and Helmy 2006), Genina Gharbia (Helmy et al. 2008, 2014), Gabbro Akarem (Helmy and Mogessie 2001, Helmy and El Mahallawi 2003), Dahanib (Khedr and Arai 2016), Mikbi (Abdallah et al. 2019), Motaghairat (Halim et al. 2016), Arabian-Nubian Shield (ANS) ophiolite according to the compilation of Gahlan et al. (2020), Oman ophiolites (Takazawa et al. 2003, Hanghøj et al. 2010, Khedr et al. 2014), Bushveld (Wager and Brown 1967), Alaskan global trend (Krause et al. 2007), Alaskan peridotites (Irvine 1974, 1976), Mantle olivine array (Takahashi et al. 1987).

2079 and 2068 Ma were documented for collisional granitic intrusions (Bananeira suite, Costa et al. 2018; Fig. 1 C, Table 5), which are similar in age to other collisional evidence in the area, such as the 2100-2070 Ma S-type granitoids (Pessoa et al. 1986, Garcia et al. 2014), the ca. 2046 Ma leucosome age from migmatites (Gomes 2013) and the ca. 2045 Ma high-grade zircon recrystallization of the Jaguaretama paragneiss (Calado et al. 2019) (Table 5). As discussed by Calado et al. (2019), the records of 2.09-2.04 Ga high-grade metamorphism in Archean-Paleoproterozoic basement rocks of the Borborema Province are also very similar to other Paleoproterozoic metamorphic ages of the surrounding cratonic domains (e.g., West Africa, Congo and São Francisco cratons).

Therefore, it is quite evident that the $2036 \pm 27$ Ma TroiaPedra Branca mafic-ultramafic magmatism intruded coeval (or slightly later) to the regional $2.07-2.04 \mathrm{Ga}$ high-grade metamorphism recorded in basement rocks of the Troia Massif and surroundings (Fig. 1 A, B and C) (Table 5). This $2036 \pm 27$ $\mathrm{Ma}$ age for the mafic-ultramafic magmatism is also very similar to the $\mathrm{U}-\mathrm{Pb}$ titanite age of $2029 \pm 27 \mathrm{Ma}$ of orogenic gold mineralization in the Paleoproterozoic greenstone belts of the Troia Massif (Costa et al. 2019) (Table 5). According to Costa et al. (2019), the ca. 2029 Ma gold mineralization in the Troia Massif is probably related to the post-collisional extensional collapse of the Eburnean-Transamazonian Orogeny. At this time, post-collisional magmatic activity is probably related to thermal perturbation or decompression as a consequence of asthenospheric upwelling following slab breakoff (von Blanckenburg and Davies 1995) or delamination (Bird 1979). Asthenosphere upwelling during post-collisional setting may generate mafic and ultramafic magmatism by melting of the overlying lithospheric mantle, whose composition was typically modified by subduction processes (e.g., Jahn et al. 1999, Zhao et al. 2005, Halim et al. 2016, Tang et al. 2017, Azer et al. 2017, Han et al. 2019, Xu et al. 2020, Das et al. 2020).

\subsection{A post-collisional Alaskan-type mafic-ultramafic magmatism}

As it was first defined, the classification of "Alaskantype" mafic-ultramafic complex was restricted to smallsized and concentric ultramafic intrusions, with only minor mafic (gabbro-diorite) expression (Taylor 1967, Irvine 1974). However, later on, according to Himmelberg and Loney (1995), zoning is not universal and may not be a criterion for recognition of Alaskan-type intrusions. In the recent years, this classification has extended a little, and many published papers use the "Alaskan-type" (or Uralian-Alaskan-type) term to generally classify mafic-ultramafic complexes worldwide, from Archean to Phanerozoic times, with similar lithologies (e.g., dunites, hornblendites, chromitites, pyroxenites, gabbros and diorites), arc-related geochemical affinity and commonly PGE mineralization (e.g. Pettigrew and Hattori 2006, Farahat and Helmy 2006, Chen et al. 2009, Tian et al. 2011, Su et al. 2012, Helmy et al. 2014, Deng et al. 2015, Habtoor et al. 2016, Khedr and Arai 2016, Yellappa et al. 2019, Cui et al. 2020, Liu et al. 2021, Han et al. 2021). On the whole, most of these works have interpreted that the Alaskantype mafic-ultramafic intrusions formed within an arcaccretionary setting, in agreement with the original tectonic environment of the type-area (North American Cordillera) of these magmatism (e.g., Himmelberg and Loney 1995). The interpretations commonly vary from island arc (Farahat and Helmy 2006, Helmy et al. 2014, Abdallah et al. 2019) to continental arc (Tseng et al. 2015, Tian et al. 2011, Eyuboglu et al. 2010, Su et al. 2012) settings. In addition, lithospheric extension in a back-arc setting (Chen et al. 2009), plume-arc interactions (Khedr and Arai 2016, Liu et al. 2021) and arccontinent collisional environments (Ishiwatari and Ichiyama 2004, Pettigrew and Hattori 2006, Webb 2014) have also been proposed. For example, according to Webb (2014), the 
TABLE 5. Geochronological data for Archean and Paleoproterozoic rocks of the Troia Massif and surrounding Ceará Central Domain.

\begin{tabular}{|c|c|c|c|c|c|}
\hline & Complex / unit & Rock type & Analytical technique & Age (Ma) & Reference \\
\hline & ARCHEAN RECORD & & & & \\
\hline \multirow{8}{*}{ 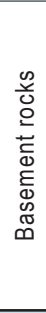 } & Cruzeta complex & Metatonalite & (U-Pb SHRIMP in zircon) & $3270 \pm 5$ & Silva et al. (2002) \\
\hline & Cruzeta complex & Metatonalite & (U-Pb isotopic dilution in zircon) & $2857 \pm 42$ & Fetter (1999) \\
\hline & Cruzeta complex & Metatonalite & (U-Pb isotopic dilution in zircon) & $2794 \pm 77$ & Fetter (1999) \\
\hline & Cruzeta complex & Metatonalite & (U-Pb SHRIMP in zircon) & $2793 \pm 6.3$ & Ganade et al. (2017) \\
\hline & Cruzeta complex & Metarhyolite & (U-Pb isotopic dilution in zircon) & $2776 \pm 65$ & Fetter (1999) \\
\hline & Cruzeta complex & Metatonalite & (U-Pb isotopic dilution in zircon) & $2773 \pm 60$ & Fetter (1999) \\
\hline & Cruzeta complex & Metatonalite & (U-Pb SHRIMP in zircon) & $2698 \pm 8$ & Ganade et al. (2017) \\
\hline & Cruzeta complex & Metatonalite & (U-Pb isotopic dilution in zircon) & $2675 \pm 64$ & Fetter (1999) \\
\hline & PALEOPROTEROZOIC & RECORD & & & \\
\hline \multirow{19}{*}{ 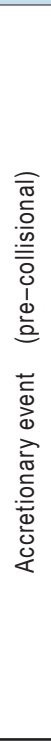 } & Algodões unit & Amphibolite (metabasalt) & (Sm-Nd whole rock isochron) & $2236 \pm 55$ & Martins et al. (2009) \\
\hline & Cipó tonalites & Metatonalite & (U-Pb LA-ICPMS in zircon) & $2190 \pm 6$ & Costa et al. (2015) \\
\hline & Mirador tonalites & Metatonalite/granodiorite & (U-Pb SHRIMP in zircon) & $2185 \pm 4$ & Costa et al. (2018) \\
\hline & Mirador tonalites & Metatonalite/granodiorite & (U-Pb LA-ICPMS in zircon) & $2181 \pm 4$ & Sousa, (2016) \\
\hline & Cipó tonalites & Metatonalite & (U-Pb LA-ICPMS in zircon) & $2180 \pm 15$ & Costa et al. (2015) \\
\hline & Cipó tonalites & Metatonalite & (Pb-Pb evaporation in zircon) & $2172 \pm 7$ & Martins et al. (2009) \\
\hline & Cipó tonalites & Metatonalite & (Pb-Pb evaporation in zircon) & $2160 \pm 9$ & Martins et al. (2009) \\
\hline & Madalena orthogneiss & Metaquartz diorite & (U-Pb isotopic dilution in zircon) & $2156 \pm 8$ & Castro (2004) \\
\hline & Cruzeta complex & Felsic metavolcanic & (U-Pb isotopic dilution in zircon) & $2151 \pm 9$ & Fetter (1999) \\
\hline & Serra da Palha ortho. & Granitic orthogneiss & (U-Pb LA-ICPMS in zircon) & $2150 \pm 16$ & Costa et al. (2015) \\
\hline & Boa Viagem complex & Bt-Hb-Orthogneiss & (U-Pb SHRIMP in zircon) & $2150 \pm 29$ & Silva et al. (2014) \\
\hline & Madalena orthogneiss & Bt-Hb-Orthogneiss & (U-Pb isotopic dilution in zircon) & $2142 \pm 20$ & Castro (2004) \\
\hline & Algodões unit & Metaquartz diorite & (U-Pb isotopic dilution in zircon) & $2140 \pm 6$ & Fetter (1999) \\
\hline & Madalena orthogneiss & Metatonalite & (Pb-Pb evaporation in zircon) & $2140 \pm 6$ & Martins et al. (2009) \\
\hline & Macaoca orthogneiss & Bt-Hb-Orthogneiss & (U-Pb isotopic dilution in zircon) & $2139 \pm 12$ & Castro (2004) \\
\hline & Boa Viagem complex & Bt-Hb-Orthogneiss & (U-Pb SHRIMP in zircon) & $2124 \pm 35$ & Silva et al. (2014) \\
\hline & Algodões unit & Metarhyolite & (U-Pb SHRIMP in zircon) & $2130 \pm 17$ & Castro (2004) \\
\hline & Macaoca orthogneiss & Metatonalite & (U-Pb isotopic dilution in zircon) & $2130 \pm 3$ & Fetter (1999) \\
\hline & Madalena orthogneiss & Metaquartz diorite & (U-Pb isotopic dilution in zircon) & $2130 \pm 3$ & Martins et al. (2009) \\
\hline \multirow{8}{*}{ 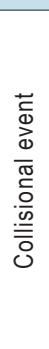 } & Boa Viagem mafic & Metagabbro & (U-Pb LA-ICPMS in zircon) & $2103 \pm 3$ & Almeida (2014) \\
\hline & Bananeira suite & Qtz-monzonite & (U-Pb SHRIMP in zircon) & $2079 \pm 4$ & Costa et al. (2018) \\
\hline & Canindé unit (?) & Leucogranite & (U-Pb LA-ICPMS in zircon) & $2070 \pm 19$ & Garcia et al. (2014) \\
\hline & Bananeira suite & Granite & (U-Pb LA-ICPMS in zircon) & $2068 \pm 5$ & Costa et al. (2018) \\
\hline & Macaoca orthogneiss & Leucosome & (U-Pb LA-ICPMS in zircon) & $2046 \pm 12$ & Gomes (2013) \\
\hline & Jaguaretama paragneiss & Metamorphic zircon rims & (U-Pb LA-ICPMS in zircon) & $2045 \pm 6$ & Calado et al. (2019) \\
\hline & $\begin{array}{l}\text { Troia-Pedra Branca } \\
\text { complex }\end{array}$ & Chromitite & (U-Pb SHRIMP in zircon) & $2036 \pm 28$ & This work \\
\hline & Gold mineralization & Calc-silicate alteration & (U-Pb LA-ICPMS in titanite) & $2029 \pm 27$ & Costa et al. (2019) \\
\hline
\end{tabular}

$\mathrm{Bt}=$ biotite, $\mathrm{Hb}=$ hornblende, $\mathrm{Qtz}=$ quartz, SHRIMP = Sensitive High Resolution Ion Microprobe, LA-ICMS = Laser Ablation Inductively

Coupled Plasma Mass Spectrometry. Error for the ages are $1 \sigma$ for the SHRIMP technique and $2 \sigma$ for the others.

emplacement of the ca. 439 Ma Fifield Alaskan-type intrusive suite in Australia is interpreted to have occurred during a brief period of regional extension that occurred immediately after the accretion (collision) of the Macquarie Arc. Similarly, the ca. 2690 Ma Archean Quetico intrusions, Superior Province, are interpreted to have emplaced during the accretion of Wawa arc to the Wabigoon subprovince (Pettigrew and Hattori 2006). Accretion of the Wawa arc to a continental margin (arccontinent collision) allowed upwelling of hot asthenospheric mantle, resulting in high degrees of partial melting in the mantle wedge to produce the ultramafic Quetico intrusions (Pettigrew and Hattori 2006). Also, as proposed by Ishiwatari and Ichiyama (2004), Alaskan-type plutons and associated ultramafic lavas of the Jurassic accretionary orogeny in Far East Russia, northeast China and Japan, may be related to episodic plume events during arc-accretionary processes. According to these authors, episodic arc-accretion may be an efficient mechanism to induce localized asthenosphere plume, which will promote high degree of mantle melting and associated mafic-ultramafic magmatism.

In this work, as aforementioned, the age of ca. $2036 \mathrm{Ma}$ for the Troia-Pedra Branca magmatism is quite younger than the 2190-2130 Ma ages found in arc-related plutons of the Troia Massif and the Ceará Central Paleoproterozoic basement (Table 5). Therefore, we suggest that the TroiaPedra Branca mafic-ultramafic magmatism could be related to a post-collisional setting, intruded during the collapse of the Eburnean/Transamazonian orogeny (see item 8.4.). As discussed before, the lithologies, the geochemical affinity and the associated PGE mineralization of the Troia-Pedra Branca mafic-ultramafic complex share similar characteristics to those of Alaskan-type complexes worldwide. In addition, other Paleoproterozoic mafic-ultramafic intrusions with arc-related geochemical signature are recognized in the 
northern Borborema Province in the Rio Grande do Norte Domain (RGND) (Fig. 1 B) (Ferreira et al., 2019). However, these mafic-ultramafic rocks have crystallization ages of ca. $2.19 \mathrm{Ga}$ (Ferreira et al., 2019), which are quite older than the $2.04 \mathrm{Ga}$ Troia-Pedra Branca complex. According to Ferreira et al. (2019), the $2.19 \mathrm{Ga}$ mafic-ultramafic intrusions of the RGND are intrusive in the 2.22-2.23 Ga arc-related calcalkaline granite-gneiss of the area, implying that the maficultramafic magmatism occurred $\sim 30$ My after a major episode of arc magmatism, probably during a late- to post-collisional Rhyacian setting. Therefore, this finding suggests that at least two stages of Paleoproterozoic mafic-ultramafic magmatism occurred in the northern Borborema Province, both intruding shortly after major events of Rhyacian arc-related felsic calc-alkaline magmatism. This outcome also refers to the above discussion about the interpretations of asthenosphere plume-arc interaction, and episodic arc-continent collision for the formation of Alaskan-type complexes (Ishiwatari and Ichiyama 2004, Pettigrew and Hattori 2006, Webb 2014).

\section{Conclusion}

The set of field, petrographic, geochemistry and $\mathrm{U}-\mathrm{Pb}$ isotopic data for metamafic and metaultramafic rocks with PGE mineralization of the Troia-Pedra Branca complex provides important insights into the characterization, petrogenesis and tectonic setting of this mafic-ultramafic magmatism. The main contributions of this work are:

- The Troia-Pedra Branca complex consists of a succession of serpentinites (after dunite), metachromitites, metaclinopyroxenite, hornblendites, metagabbros and minor metagabbro-diorites.

- The presence of hornblende-bearing metagabbros and hornblendites in the study igneous complex suggests that amphiboles played an important role in the magmatic differentiation, which is typical of water-bearing calc-alkaline basaltic series.

- Textural relationships suggest that the PGM have been recrystallized (and locally remobilized?) during metamorphism. However, the PGEs are not added to metachromitites from an external source, and they are probably derived by the alteration of primary (igneous) PGM, originally located interstitially to the chromite grains.

- The whole-rock geochemical data show that the metagabbros of the Troia-Pedra Branca complex have a clear affinity to calc-alkaline basaltic series, and have similar arc-related signatures to those of Alaskan-type complexes. Chromite and olivine mineral chemistry also indicate an arcrelated (Alaskan-type) affinity.

- Our reported U-Pb SHRIMP zircon age of $2036 \pm 27 \mathrm{Ma}$ for the Troia-Pedra Branca metachromitites is quite younger than the 2190-2130 Ma ages found in arc-related plutons of the study area; therefore, the Troia-Pedra Branca maficultramafic magmatism may be related to a post-collisional setting, intruded during the collapse of the Eburnean/ Transamazonian orogeny.

\section{Acknowledgments}

This paper is a contribution from the Geological Survey of Brazil through the project "Províncias Minerais do Brasil Área Troia-Pedra Branca", which is funded by the Brazilian
Federal Government. FG Costa is grateful to the Pedra Branca Mineração Ltda. for the kind provision and access to drill core samples. WS Amaral would like to thank Cardiff University for institutional support during the postdoctoral period and the technician Duncan Muir for ongoing A-SEMrelated assistance. WSA also thanks the Conselho Nacional de Desenvolvimento Científico e Tecnológico (CNPq) for the research felowship. We would like to thank the editor Carlos Spier and the reviewers Eduardo Mansur and Avish Kumar for their critical comments.

\section{Appendix}

Standard data for whole-rock and mineral chemical analyses are available at https://jgsb.cprm.gov.br/index.php/ journal/issue/view/25

\section{References}

Abdallah S.E., Ali S., Obeid M.A. 2019. Geochemistry of an Alaskan-type mafic-ultramafic complex in Eastern Desert, Egypt: new insights and constraints on the Neoproterozoic island arc magmatism. Geoscience Frontiers, 10(3), 941-955. https://doi.org/10.1016/j.gsf.2018.04.009

Almeida F.F.M., Hasui Y. Brito Neves B.B., Fuck R.A. 1981. Brazilian structural provinces: an introduction. Earth Science Reviews, 17(1-2), 1-29. https://doi.org/10.1016/0012-8252(81)90003-9

Almeida R.S. 2014. Geologia, Geoquímica e Geocronologia da Suíte Intrusiva Máfica-Ultramáfica de Boa Viagem, Ceará, Brasil. MSc Dissertation, Universidade Federal do Ceará, Fortaleza, 103 p.

Amaral W.S. 2010. Análise geoquímica, geocronológica e termobarométrica das rochas do alto grau metamórfico adjacentes ao arco magmático de Santa Quitéria, NW da Província Borborema. PhD Thesis, Universidade Estadual de Campinas, Campinas, 248 p. Available on line at: http://repositorio.unicamp.br/ispui/handle/ REPOSIP/287674 / (accessed on 2 August 2021)

Amaral W.S., Santos T.J.S., Wernick E., Nogueira Neto J.A., Dantas E.L., Matteini M., 2012. High-pressure granulites from Cariré, Borborema Province, NE Brazil: tectonic setting, metamorphic conditions and $\mathrm{U}-\mathrm{Pb}$, Lu-Hf and Sm-Nd geochronology. Gondwana Research, 22(34), 892-909. https://doi.org/10.1016/j.gr.2012.02.011

Angeli N. 2005. Platinum Group Minerals in Eastern Brazil: geology and occurrences in chromitite and placers. Platinum Metals Review, 49(1), 41-53. https://doi.org/10.1595/147106705X24391

Angeli N., Bevenutti C.F., Antunes L.A., Campos M.C., Mamani R. 2009. Cromititos do Complexo de Pedra Branca: química mineral e platinóides associados, Ceará, Brasil. In: Simpósio de Geologia do Nordeste, Fortaleza, 23. CD ROM

Angeli N., Fleet M.E., Kingston D.M., Nogueira Neto J.A. 1993. Ir-bearing sperrylite and $\mathrm{Pd}$-bearing hollingworthite in chromitites from the Pedra Branca Complex, Ceará, Brazil. Brazilian Meeting on PGEs, I, Brasília, 44-46

Arai S. 1992. Chemistry of chromian spinel in volcanic rocks as a potential guide to magma chemistry. Mineralogical Magazine, 56(383), 173184. https://doi.org/10.1180/minmag.1992.056.383.04

Arculus R.J. 1994. Aspects of magma genesis in arcs. Lithos, 33(1-3), 189-208. https://doi.org/10.1016/0024-4937(94)90060-4

Arthaud M.H., Caby R., Fuck R.A., Dantas E.L., Parente C.V. 2008. Geology of the northern Borborema Province, NE Brazil and its correlation with Nigeria, NW Africa. In: Pankhurst R.J., Trouw R.A.J., Brito Neves B.B., de Wit M.J. (eds). West Gondwana: Pre-Cenozoic correlations across the South Atlantic Region. Geological Society of London, Special Publications, 294, 49-67. https://doi.org/10.1144/SP294.4

Azer M.K., Gahlan H.A., Asimow P.D., Al-Kahtany K. 2017. The late Neoproterozoic Dahanib mafic-ultramafic intrusion, South eastern Desert, Egypt: is it an Alaskan-type or a layered intrusion? American Journal of Science, 317(8), 901-940. https://doi. org/10.2475/08.2017.02

Barnes S.J., Lightfoot P.C. 2005. Formation of magmatic nickel sulfide deposits and processes affecting their copper and platinum group element contents. In: Hedenquist J.W., Thompson J.F.H., Goldfarb R.J., Richards J.P. Economic Geology 100th Anniversary, 179-213. https://doi.org/10.5382/AV100.08 
Barnes S.J., Ripley E.M. 2016. Highly siderophile and strongly chalcophile elements in magmatic ore deposits. Reviews in Mineralogy and Geochemistry, 81(1), 725-774. https://doi.org/10.2138/rmg.2016.81.12

Barnes S.J., Roeder P.L. 2001. The range of spinel compositions in terrestrial mafic and ultramafic rocks. Journal of Petrology, 42(12), 2279-2302. https://doi.org/10.1093/petrology/42.12.2279

Barrueto H.R., Hunt W. 2010. Main features of the Pt-Pd Chromitite-type ore deposit, Tróia Unit, Cruzeta Complex, Northeast Brazil: Insights provide by microscopic and chemical approaches. In: International Platinum Symposium, 11, Sudbury, Canada.

Batanova V.C., Pertsev A.N., Kamenetsky V.S., Ariskin A.A., Mochalov A.G., Sobolev A.V. 2005. Crustal evolution of island-arc ultramafic magma: Galmoenan pyroxenite-dunite plutonic complex, Koryak Highland (Far East Russia). Journal of Petrology, 46(7), 1345-1366. https://doi.org/10.1093/petrology/egi018

Beard J.S. 1986. Characteristic mineralogy of arc-related cumulate gabbros: implications for the tectonic setting of gabbroic plutons and for andesite genesis. Geology, 14(10), 848-851. https://doi. org/10.1130/0091-7613(1986)14<848:CMOACG>2.0.CO;2

Bhat I.M., Ahmad T., Subba Rao D.V. 2019. Alteration of primary Cr-spinel mineral composition from the Suru Valley ophiolitic peridotites, Ladakh Himalaya: their low-temperature metamorphic implications. Journal of Earth System Science, 128, 188. https://doi.org/10.1007/s12040-019$1222-6$

Bird P. 1979. Continental delamination and the Colorado Plateau. Journal of Geophysical Research: Solid Earth, 84(B13), 7561-7571. https://doi. org/10.1029/JB084iB13p07561

Bonavia F., Diella V., Ferrario A. 1993. Precambrian podiform chromitites from Kenticha Hill, southern Ethiopia. Economic Geology, 88(1), 198202. https://doi.org/10.2113/gsecongeo.88.1.198

Boynton W.V. 1984. Cosmochemistry of the rare earth elements: meteorite studies. In: Henderson P. Rare earth element geochemistry. Amsterdam, Elsevier, 63-114. https://doi.org/10.1016/B978-0-44442148-7.50008-3

Brito Neves B.B. 1975. Regionalização geotectônica do precambriano nordestino. PhD Thesis, Instituto de Geociências, Universidade de São Paulo, São Paulo, 198 p. https://doi.org/10.11606/T.44.1975.tde21062013-104857

Brito Neves B.B., Cordani U.G. 1991. Tectonic evolution of South America during the late proterozoic. Precambrian Research, 53(1-2), 23-40. https://doi.org/10.1016/0301-9268(91)90004-T

Burns L.E. 1985. The Border Ranges ultramafic and mafic complex, south-central Alaska: cumulate fractionates of island-arc volcanics. Canadian Journal of Earth Sciences, 22(7), 1028-1038. https://doi. org/10.1139/e85-106

Caby R., Arthaud M.H. 1986. Major Precambrian nappes of the Brazilian belt, Ceara, northeast Brazil. Geology, 14(10), 871-874. https://doi. org/10.1130/0091-7613(1986)14<871:MPNOTB >2.0.CO;2

Calado B.O., Costa F.G., Gomes I.P., Rodrigues J.B. 2019. Evidence for ca. $2046 \mathrm{Ma}$ high-grade metamorphism in Paleoproterozoic metasedimentary rocks of the northern Borborema Province, NE Brazil: constraints from U-Pb (LA-ICP-MS) zircon ages. Journal of the Geological Survey of Brazil, 2(3), 137-150. https://doi.org/10.29396/ igsb.2019.v2.n3.1

Castillo P.R., Janney P.E., Solidum R.U. 1999. Petrology and geochemistry of Camiguin Island, southern Philippines: insights into the source of adakite and other lavas in a complex arc tectonic setting. Contributions to Mineralogy and Petrology, 134, 33-51. https://doi.org/10.1007/ s004100050467

Castro N.A. 2004. Evolução Geológica Proterozóica da Região entre Madalena e Taperuaba, Domínio Tectônico Ceará Central (Província Borborema). PhD Thesis, Instituto de Geociências, Universidade de São Paulo, São Paulo, 221p. https://doi.org/10.11606/T.44.2005.tde31032015-112038

Chen B., Suzuki K., Tian W., Jahn B.M., Ireland T. 2009. Geochemistry and $\mathrm{Os}-\mathrm{Nd}-\mathrm{Sr}$ isotopes of the Gaositai Alaskan-type ultramafic complex from the northern North China Craton: Implications for mantle-crust interaction. Contributions to Mineralogy and Petrology, 158, 683-702. https://doi.org/10.1007/s00410-009-0404-7

Costa F.G., Klein E.L., Galarza M.A., Pineo T.R.G. 2019. Structural features and age of gold mineralization in the Troia Massif, Borborema Province, NE Brazil: a Paleoproterozoic ( 2029 Ma) hypozonal orogenic gold deposit overprinted by the late Neoproterozoic Brasiliano/ Pan-African orogeny. Journal of South American Earth Sciences, 93, 119-139. https://doi.org/10.1016/j.jsames.2019.05.003
Costa F.G., Klein E.L., Lafon J.M., Milhomen Neto J.M., Galarza M.A., Rodrigues J.B., Naleto J.L.C., Corrêa-Lima R.G. 2018. Geochemistry and $\mathrm{U}-\mathrm{Pb}-\mathrm{Hf}$ zircon data for plutonic rocks of the Troia Massif, Borborema Province, NE Brazil: evidence for reworking of Archean and juvenile Paleoproterozoic crust during Rhyacian accretionary and collisional tectonics. Precambrian Research, 311, 167-194. https://doi.org/10.1016/j.precamres.2018.04.008

Costa F.G., Oliveira E.P., McNaughton N. 2011. The Fazenda Gavião granodiorite and associated potassic plutons as evidence for Palaeoproterozoic arc-continent collision in the Rio Itapicuru greenstone belt, Brazil. Journal of South American Earth Sciences, 32(2), 127-141. https://doi.org/10.1016/j.jsames.2011.04.012

Costa F.G., Palheta E.S.M., Rodrigues J.B., Gomes I.P., Vasconcelos A.M. 2015. Geochemistry and U-Pb zircon ages of plutonic rocks from the Algodões granite-greenstone terrane, Troia Massif, northern Borborema Province, Brazil: implications for Paleoproterozoic subduction-accretion processes. Journal of South American Earth Sciences, 59, 45-68. https://doi.org/10.1016/j.jsames.2015.01.007

Cox K.G., Bell J.D., Pankhurst R.J. 1979. The interpretation of igneous rocks. Dordrecht, Springer, 450p. https://doi.org/10.1007/978-94017-3373-1

Cui M.M, Su B.X., Wang J., Chen K.Y., Sakyi P.A., Tang D.M., He Y.P., Sun J.G., Anani C.Y., Gao D.L. 2020. Alaskan-type nature and PGE mineralization of the Wuxing mafic-ultramafic complex in eastern part of the Central Asian Orogenic Belt. Ore Geology Reviews, 123, 103566. https://doi.org/10.1016/j.oregeorev.2020.103566

Das S., Goswami B., Bhattacharyya C. 2020. Physico-chemical conditions of crystallization and composition of source magma of the Grenvillian post-collisional mafic-ultramafic rocks in the Chhotanagpur Gneissic Complex, Eastern India. Journal of Earth System Science, 129, 89. https://doi.org/10.1007/s12040-019$\underline{1313-4}$

Davidson J., Turner S., Handley H., Macpherson C., Dosseto A. 2007. Amphibole 'sponge' in arc crust? Geology, 35(9), 787-790. https:// doi.org/10.1130/G23637A.1

Delor C., Lahondère D., Egal E., Lafon J.M., Cocherie A., Guerrot C., Rossi P., Trufert C., Theveniaut H., Phillips D., Avelar V.G. 2003. Transamazonian crustal growth and reworking as revealed by the 1:500,000-scale geological map of French Guiana. 2nd ed. Geologie de la France, p. 2-3-4, 5-57.

Deng Y.F., Yuan F., Zhou T., White N.C., Zhang D., Guo X., Zhang R., Zhao B. 2015. Zircon U-Pb geochronology, geochemistry, and Sr$\mathrm{Nd}$ isotopes of the Ural-Alaskan type Tuerkubantao mafic-ultramafic intrusion in southern Altai orogen, China: petrogenesis and tectonic implications. Journal of Asian Earth Sciences, 113(1), 36-50. https:// doi.org/10.1016/i.jseaes.2015.05.007

Dick H.J.B., Bullen T. 1984. Chromian spinel as a petrogenetic indicator in abyssal and alpine-type peridotites and spatially associated lavas. Contributions to Mineralogy and Petrology, 86, 54-76. https:// doi.org/10.1007/BF00373711

Droop G.T.R. 1987. A general equation for estimating Fe3+ concentrations in ferromagnesian silicates and oxides from microprobe analyses, using stoichiometric criteria. Mineralogical Magazine, 51(361), 431435. https://doi.org/10.1180/minmag.1987.051.361.10

Eyuboglu Y., Dilek Y., Bozkurt E., Bektas O., Rojay B., Sen C. 2010. Structure and geochemistry of an Alaskan-type ultramafic-mafic complex in the Eastern Pontides, NE Turkey. Gondwana Research, 18(1), 230-252. https://doi.org/10.1016/i.gr.2010.01.008

Farahat E.S., Helmy H.M. 2006. Abu Hamamid Neoproterozoic Alaskan-type complex, South eastern Desert, Egypt. Journal of African Earth Sciences, 45(2), 187-197. https://doi.org/10.1016/j. jafrearsci. 2006.02.003

Ferrario A., Garuti G. 1988. Platinum-group minerals in chromite-rich horizons of the Niquelandia Complex (central Goias, Brazil). In: Prichard H.M., Potts P.J., Bowles J.F.W., Cribb S.J. (eds.). GeoPlatinum 87. Dordrecht, Springer. https://doi.org/10.1007/978-94009-1353-0 30

Fershtater G.B., Bea F., Pushkarev E.V., Garuti G., Montero P., Zaccarini F. 1999. Insight into the petrogenesis of the Urals Platinum Belt: new geochemical evidence. Geochemistry International 37(4), 302-319.

Fetter A.H. 1999. U/Pb and Sm/Nd Geocronological Constraints on the Crustal Framework and Geologic History of Ceará State, NW Borborema Province, NE Brazil: implications for the Assembly of Gondwana. PhD Thesis, Departament of Geology, Kansas University, Lawrence, 164p. 
Fetter A.H., Van Schmus W.R., Santos T.J.S., Nogueira Neto J.A., Arthaud, M.H. 2000, U-Pb and Sm-Nd geochronological constraints on the crustal evolution and basement architecture of Ceará State, NW Borborema Province, NE Brazil: implications for the existence of the Paleoproterozoic Supercontinent "Atlantica". Revista Brasileira de Geociências, 30(1), 102-106. https://doi.org/10.25249/0375$\underline{7536.2000301102106}$

Feybesse J.L., Billa M., Guerrot C., Duguey J.L.L., Milesi J.P., Bouchot V. 2006. The Palaeoproterozoic Ghanaian province: geodynamic model and ore controls, including regional stress modeling. Precambrian Research, 149(3-4), 149-196. https://doi.org/10.1016/j. precamres.2006.06.003

Fleet M.E., Angeli N., Pan Y., 1993. Oriented chlorite lamellae in chromite from the Pedra Branca Mafic-Ultramafic Complex, Ceará, Brazil. American Mineralogist, 78(1-2), 68-74. Available on line at: https:// pubs.geoscienceworld.org/msa/ammin/article/78/1-2/68/105225/ Oriented-chlorite-lamellae-in-chromite-from-the / (accessed on 16 August 2021)

Gahlan H.A., Azer M.K., Asimow P.D., Mubarak H.S., Al-Kahtany K.M. 2020. Petrological characteristics of the Neoproterozoic Ess ophiolite mantle section, Arabian Shield, Saudi Arabia: a mineral chemistry perspective. International Journal of Earth Sciences, 109, 239-251. https://doi.org/10.1007/s00531-019-01799-3

Ganade de Araújo C.E., Basei M.A.S., Grandjean F.C., Armstrong R., Brito R.S. 2017. Contrasting Archaean (2.85-2.68 Ga) TTGs from the Tróia Massif (NE-Brazil) and their geodynamic implications for flat to steep subduction transition. Precambrian Research297, 1-18. https:// doi.org/10.1016/j.precamres.2017.05.007

Ganade de Araújo C.E.G., Cordani U.G., Basei M.A.S., Castro N.A., Sato K. 2012. U-Pb detrital zircon provenance of metasedimentary rocks from the Ceará Central and Médio Coreaú Domains, Borborema Province, NE-Brazil: tectonic implications for a long-lived Neoproterozoic active continental margin. Precambrian Research, 206, 36-51. https://doi. org/10.1016/j.precamres.2012.02.021

Ganade de Araújo C.E.G., Pinéo T.R.G., Caby R., Costa F.G., Cavalcante J.C., Vasconcelos A.M., Rodrigues J.B. 2010. Provenance of the Novo Oriente Group, southwestern Ceará Central Domain, Borborema Province (NE-Brazil): a dismembered segment of a magma poorpassive margin or a restricted rift-related basin? Gondwana Research, 18(2-3), 497-513. https://doi.org/10.1016/j.gr.2010.02.001

Gao J., John T., Klemb R., Xiong X. 2007. Mobilization of Ti-Nb-Ta during subduction: evidence from rutile-bearing dehydration segregations and veins hosted in eclogite, Tianshan, NW China. Geochimica et Cosmochimica Acta, 71(20), 4974-4996. https://doi.org/10.1016/j. gca.2007.07.027

Garcia M.G.M., Santos T.J.S., Amaral W.S. 2014. Provenance and tectonic setting of neoproterozoic supracrustal rocks from the Ceará Central Domain, Borborema Province (NE Brazil): constraints from geochemistry and detrital zircon ages. International Geology Review, 56(4), 481-500. https://doi.org/10.1080/00206814.2013.875489

Garuti G., Pushkarev E.V., Zaccarini F., Cabella R., Anikina E. 2003. Chromite composition and platinum-group mineral assemblage in the Uktus UralianAlaskan-type complex (Central Urals, Russia). Mineralium Deposita, 38, 312-326. https://doi.org/10.1007/s00126-003-0348-1

Garuti. G., Pushkarev E.V., Zaccarini F. 2002. Composition and paragenesis of $\mathrm{Pt}$ alloys from chromitites of Uralian Alaskan-type Kytlym and Uktus complexes, northern and central Urals, Russia. The Canadian Mineralogist, 40(4), 1127-1146. https://doi.org/10.2113/ gscanmin.40.4.1127

Geisler T., Schaltegger U., Tomaschek F. 2007. Re-equilibration of zircon in aqueous fluids and melts. Elements, 3(1), 43-50. https://doi. org/10.2113/gselements.3.1.43

Gomes E.N. 2013. Protominérios e minérios de manganês de Juá-CE. MSc Dissertation, Universidade Federal do Ceará, Fortaleza, p. 102. Available on line at: http://www.repositorio.ufc.br/handle/riufc/16909 / (accessed on 16 August 2021)

Gomes J.R.C., Gatto C.M.P.P., Souza G.M.C., Luz D.S., Pires J.L., Teixeira, W. 1981. Geologia: mapeamento regional. In: Brasil. Ministério de Minas e Energia. Projeto RADAMBRASIL. Folhas SB. 24/25 Jaguaribe/Natal. Levantamento de recursos naturais, 23. Rio de Janeiro, 27-176. Available on line at: https://biblioteca.ibge.gov.br/ biblioteca-catalogo.html?id=216333\&view=detalhes / (accessed on 16 August 2021)

González Jiménez J.M., Kerestedjian T., Proenza Fernández J.A., Gervilla Linares F. 2009. Metamorphism on Chromite Ores from the
Dobromirtsi Ultramafic Massif, Rhodope Mountains (SE Bulgaria). Geologica Acta, 7(4), 413-429. https://doi.org/10.1344/104.000001447

Grieco G., Merlini A. 2012. Chromite alteration processes within Vourinos ophiolite. International Journal of Earth Sciences, 101, 1523-1533. https://doi.org/10.1007/s00531-011-0693-8

Habtoor A., Ahmed A.H., Harbi H. 2016. Petrogenesis of the Alaskan-type mafic-ultramafic complex in the Makkah quadrangle, western Arabian Shield, Saudi Arabia. Lithos, 263, 33-51. https://doi.org/10.1016/j. lithos.2016.08.014

Halim A.H.A., Helmy H.M., El-Rahman Y.M.A., Shibata T., Mahallawi M.M.E., Yoshikawa M., Arai, S. 2016. Petrology of the Motaghairat mafic-ultramafic complex, Eastern Desert, Egypt: a high-Mg postcollisional extension-related layered intrusion. Journal of Asian Earth Sciences, 116, 164-180. https://doi.org/10.1016/j.jseaes.2015.11.015

Hall R.P., Hughes D.J. 1990. Norite magmatism. In: Hall R.P., Hughes D.J. (eds.). Early precambrian basic magmatism. Glasgow, Blackie, p. 83110. https://doi.org/10.1007/978-94-009-0399-9 5

Han Y.S., Santosh M., Roberts N.M.W., Samuel V.O. 2019. Post-collisional ultramafic complex in the northern North China Craton: implications for crust-mantle interaction. Lithos, 348-349, 105209. https://doi. org/10.1016/j.lithos.2019.105209

Han Y.S., Santosh M., Samuel V.O. 2018. The Fangmayu Alaskan-type ultramafic intrusion: implications for Paleoproterozoic assembly of the North China Craton. Precambrian Research, 315, 201-221. https://doi. org/10.1016/j.precamres.2018.07.027

Han Y.S., Waterton P., Szilas K., Santosh M., Kirkland C.L. 2021. Origin of high-Cr stratiform chromitite in the Fangmayu Alaskan-type ultramafic intrusion, North China Craton. Precambrian Research, 355, 106096. https://doi.org/10.1016/j.precamres.2021.106096

Hanghøj K., Kelemen P.B., Hassler D., Godard M. 2010. Composition and genesis of depleted mantle peridotites from the Wadi Tayin massif, Oman ophiolite; major and trace element geochemistry, and Os isotope and PGE systematics. Journal of Petrology, 51(1-2), 201-227. https://doi.org/10.1093/petrology/egp077

Hastie A.R., Kerr A.C., Pearce J.A., Mitchell S.F. 2007. Classification of altered volcanic island arc rocks using immobile trace elements: development of the Th-Co discrimination Diagram. Journal of Petrology, 48(12), 23412357. https://doi.org/10.1093/petrology/egm062

Hatton C.J., Von Gruenewaldt G. 1990. Early Precambrian layered intrusions. In: Hall R.P., Hughes D.J. (eds.). Early precambrian basic magmatism. Glasgow, Blackie, p. 56-82. https://doi.org/10.1007/97894-009-0399-9 4

Helmy H.M., Abd El-Rahman Y.M., Yoshikawa M., Shibata T., Arai S., Tamura A., Kagami H. 2014. Petrology and Sm-Nd dating of the Genina Gharbia Alaskan-type complex (Egypt): insights into deep levels of Neoproterozoic island arcs. Lithos, 198-199, 263-280. https:// doi.org/10.1016/j.lithos.2014.03.028

Helmy H.M., El Mahallawi M.M. 2003. Gabbro Akarem mafic-ultramafic complex, Eastern Desert, Egypt: a late Precambrian analogue of Alaskan-type complexes. Mineralogy and Petrology, 77, 85-108. https://doi.org/10.1007/s00710-001-0185-9

Helmy H.M., Mogessie A. 2001. Gabbro Akarem, Eastern Dessert, Egypt: $\mathrm{Cu}-\mathrm{Ni}-\mathrm{PGE}$ mineralization in a concentrically zoned mafic-ultramafic complex. Mineralium Deposita, 36, 58-71. https://doi.org/10.1007/ s001260050286

Helmy H.M., Yoshikawa M., Shibata T., Arai S., Tamura A. 2008. Corona structure from arc mafic-ultramafic cumulates: the role and chemical characteristics of late-magmatic hydrous liquids. Journal of Mineralogical and Petrological Sciences, 103(5), 333-344. https://doi. org/10.2465/jmps.070906

Himmelberg G.R., Loney R.A., Craig J.T. 1986. Petrogenesis of the ultramafic complex at the Blashke Islands, southeastern Alaska. US Geological Survey Bulletin 1662, 1-14. https://doi.org/10.3133/b1662

Himmelberg G.R., Loney R.A. 1995. Characteristics and petrogenesis of alaskan-type ultramafic-mafic intrusions, Southeastern Alaska. US Geological Survey Professional Paper, 1564, 47 p. https://doi. org/10.3133/pp1564

Irvine T.N. 1967. Chromium spinel as a petrogenetic indicator. Part 2. Petrologic applications. Canadian Journal of Earth Sciences, 4, 71103. https://doi.org/10.1139/e67-004

Irvine T.N. 1974. Petrology of the Duke Island ultramafic complex southern Alaska. GSA Memoir, 138, 240. https://doi.org/10.1130/MEM138

Irvine T.N. 1976. Alaskan-type ultramafic-gabbro bodies in the Aiken Lake, McConnel Creek, and Toodagoone map-areas. Geological Survey of Canada, 76-1A, p. 76-81. https://doi.org/10.4095/104168 
Irvine T.N., Baragar W.R.A. 1971. A guide to the chemical classification of the common volcanic rocks. Canadian Journal of Earth Sciences, 8, 523-548. https://doi.org/10.1139/e71-055

Ishiwatari A., Ichiyama Y. 2004. Alaskan-Type plutons and ultramafic lavas in far East Russia, Northeast China, and Japan. International Geology Review, 46(4), 316-331. https://doi.org/10.2747/0020-6814.46.4.316

Jahn B.-M., Wu F.Y., Lo C.H., Tsai C.H. 1999. Crustal-mantle interaction induced by deep subduction of the continental crust: geochemical and $\mathrm{Sr}-\mathrm{Nd}$ isotopic evidence from post-collisional mafic-ultramafic intrusions of the northern Dabie complex, central China. Chemical Geology, 157(1-2), 119-146. https://doi.org/10.1016/S00092541(98)00197-1

Janousek V., Farrow G., Erban V. 2006. Interpretation of whole-rock geochemical data in igneous geochemistry: introducing Geochemical Data Toolkit (GCDkit). Journal of Petrology, 47(6), 1255-1259. https:// doi.org/10.1093/petrology/egl013

Johan Z., Ohnenstetter M., Slansky E., Barron L.M., Suppel D. 1989. Platinum mineralization in the Alaskan-type intrusive complexes near Fifield, New South Wales, Australia part 1. platinum-group minerals in clinopyroxenites of the Kelvin Grove prospect, owendale intrusion. Mineralogy and Petrology 40, 289-309. https://doi.org/10.1007/ BF01164604

Kamenetsky V.S., Crawford A.J., Meffre S. 2001. Factors controlling chemistry of magmatic spinel: an empirical study of associated olivine, $\mathrm{Cr}$-spinel and melt inclusions from primitive rocks. Journal of Petrology, 42(4), 655-671. https://doi.org/10.1093/petrology/42.4.655

Khedr M., Arai S. 2016. Petrology of a Neoproterozoic Alaskantype complex from the Eastern Desert of Egypt: implications for mantle heterogeneity. Lithos, 263, 15-32. https://doi.org/10.1016/j. lithos.2016.07.016

Khedr M.Z., Arai S., Python M., Tamura A. 2014. Chemical variations of abyssal peridotites in the central Oman ophiolite: evidence of oceanic mantle heterogeneity. Gondwana Research, 25(3), 1242-1262. https:// doi.org/10.1016/j.gr.2013.05.010

Klein E.L., Lopes E.C.S., Rodrigues J.B., Souza-Gaia S.M., Cordani U.G. 2020. Rhyacian and Neoproterozoic magmatic associations of the Gurupi Belt, Brazil: implications for the tectonic evolution, and regional correlations. Geoscience Frontiers, 11(6), 2243-2269. https:// doi.org/10.1016/j.gsf.2020.02.016

Klein E.L., Rodrigues J.B., Lopes E.C.S., Soledade G.L. 2012. Diversity of Rhyacian granitoids in the basement of the Neoproterozoic-Early Cambrian Gurupi Belt, northern Brazil: geochemistry, U-Pb zircon geochronology, and $\mathrm{Nd}$ isotope constraints on the Paleoproterozoic magmatic and crustal evolution. Precambrian Research, 220-221, 192-216. https://doi.org/10.1016/j.precamres.2012.08.007

Krause, J., Brügmann G.E., Pushkarev E.V. 2007. Accessory and rock forming minerals monitoring the evolution of zoned mafic-ultramafic complexes in the Central Ural Mountains. Lithos, 95(1-2), 19-42. https://doi.org/10.1016/j.lithos.2006.07.018

Krause J. 2008. Petrogenetic evolution of Uralian-Alaskan-type maficultramafic complexes in the southern and middle Urals, Russia. PhD Thesis, Johannes Gutenberg University, Mainz, Germany, 175p. http:// doi.org/10.25358/openscience-3234

Krause J., Brügmann G.E., Pushkarev E.V. 2011. Chemical composition of spinel from Uralian-Alaskan-type Mafic-Ultramafic complexes and its petrogenetic significance. Contributions to Mineralogy and Petrology, 161, 255-273. https://doi.org/10.1007/s00410-010-0530-2

Kuno H. 1966. Lateral variation of basaltic magma types across continental margins and island arcs. Bulletin Volcanologique, 29, 195-222. https:// doi.org/10.1007/BF02597153

Kutyrev A., Siderov E.G., Kamenetsky V.S., Chubarov V.M., Chayka I.F. 2021. Platinum mineralization and geochemistry of the Matysken zoned Ural-Alaskan type complex and related placer (Far East Russia). Ore Geology Reviews, 130, 103947. https://doi.org/10.1016/j. oregeorev.2020.103947

Larocque J., Canil D. 2010. The role of amphibole in the evolution of arc magmas and crust: The case from the Jurassic Bonanza arc section, Vancouver Island, Canada. Contributions to Mineralogy and Petrology, 159, 475-492. https://doi.org/10.1007/s00410-009-0436-z

Leblanc M., Nicolas A. 1992. Ophiolitic chromites. International Geology Review, 34(7), 653-686. https://doi.org/10.1080/00206819209465629

Liégeois J.P., Claessens W., Camara D., Klerkx J. 1991. Short-lived Eburnean orogeny in southern Mali. Geology, tectonics, $\mathrm{U}-\mathrm{Pb}$ and $\mathrm{Rb}-$ Sr geochronology. Precambrian Researh, 50(1-2), 111-136. https://doi. org/10.1016/0301-9268(91)90050-K
Liu J., Hattori K., Wang J. 2017. Mineral inclusions in chromite from the chromite deposit in the Kudi Ophiolite, Tibet, Proto-Tethys. Acta Geological Sinica, 91(2), 469-485. https://doi.org/10.1111/1755-6724.13112

Liu L., Zhang Z., Cheng Z., Santosh M., Liu B., Li H. 2021. Ultramafic xenoliths from aillikites in the Tarim large igneous province: implications for Alaskan-type affinity and role of subduction. Lithos, 380-381, 105902. https://doi.org/10.1016/..lithos.2020.105902

Lomas S., Shahkar A., Hul B. 2019. Pedra Branca Project may 2019 resource: estimate technical report: Pedra Branca Project, Ceará State, Brazil. Updated: August 12, 2019. Consulting prepared for ValOre Metals Corp., NI 43-101 Resource Estimate Technical Report - Pedra Branca Project, Ceará State, Brazil. Technical Report, 138 p. Available on line at: http://valoremetals.com/_resources/reports/ Pedra-Branca-Project-Technical-Report-2019.pdf / (accessed on 18 August 2021).

Lorand J.P., Ceuleneer G. 1989. Silicate and base-metal sulfide inclusions in chromites from the Maqsad area (Oman ophiolite, Gulf of Oman): a model for entrapment. Lithos, 22(3), 173-190. https://doi. org/10.1016/0024-4937(89)90054-6

Ludwig K.R. 2003. Isoplot/Ex Version 3. 00: A Geochronological Toolkit for Microsoft Excel. Berkeley Geochronology Center, Berkeley, CA. Available on line at: https://searchworks.stanford.edu/view/6739593 / (accessed on 18 August 2021).

MacTavish A.D. 1999. The mafic-ultramafic intrusions of the AitikokanQuetico area northwestern Ontario. Ontario Geological Survey, Open File Report. 5997, 127. Available on line at: http://www.geologyontario. mndmf.gov.on.ca/mndmfiles/pub/data/imaging/OFR5997/OFR5997. pdf / (accessed on 18 August 2021).

Mansur E.T., Ferreira Filho C.F. 2017. Chromitites from the Luanga Complex, Carajás, Brazil: stratigraphic distribution and clues to processes leading to post-magmatic alteration. Ore Geology Reviews, 90, 110-130. https://doi.org/10.1016/j.oregeorev.2017.03.016

Martins G., Oliveira E.P, Lafon J.M. 2009. The Algodões amphibolitetonalite gneiss sequence, Borborema Province, NE Brazil: geochemical and geocronological evidence for Paleoproterozoic accretion of oceanic plateu/back-arc basalts and adakitic plutons. Gondwana Research, 15(1), 71-85. https://doi.org/10.1016/j.gr.2008.06.002

McFarlane H.B., Aileres L., Betts P., Ganne J., Baratoux L., Jessell M.W., Block S. 2019. Episodic collisional orogenesis and lower crust exhumation during the Palaeoproterozoic Eburnean Orogeny: evidence from the Sefwi Greenstone Belt, West African Craton. Precambrian Research, 325, 88-110. https://doi.org/10.1016/j. precamres.2019.02.012

Macpherson C.G., Dreher S.T., Thirlwall M.F. 2006. Adakites without slab melting: high pressure differentiation of island arc magma, Mindanao, the Philippines. Earth and Planetary Science Letters, 243(3-4), 581593. https://doi.org/10.1016/j.epsl.2005.12.034

McReath I., Faraco M.T.L. 2006. Paleoproterozoic greenstone-granite belts in Northern Brazil and the former Guyana Shield - West African Craton province. Geologia USP. Série Científica, 5(2), 49-63. http:// dx.doi.org/10.5327/S1519-874X2006000100004

Melcher F., Grum W., Simon G., Thalhammer T.V., Stumpfl E.F. 1997. Petrogenesis of the ophiolitic giant chromite deposits of Kempirsai, Kazakhstan: a study of solid and fluid inclusions in chromite. Journal of Petrology, 38(10), 1419-1458. https://doi.org/10.1093/petroj/38.10.1419

Merlini A., Grieco G., Diella V. 2009. Ferritchromite and chromianchlorite formation in mélange-hosted Kalkan chromitite (Southern Urals, Russia). American Mineralogist, 94, 1459-1467. https://doi. org/10.2138/am.2009.3082

Miyashiro A. 1974. Volcanic rock series in island arcs and active continental margins. American Journal of Science, 274(4), 321-355. https://doi.org/10.2475/ajs.274.4.321

Monié P., Caby R., Arthaud M.H. 1997. The neoproterozoic Brasiliano Orogeny in Northeast Brazil: 40Ar39Ar and petrostructural data from Ceará. Precambrian Research, 81(3-4), 241-264. https://doi. org/10.1016/S0301-9268(96)00037-X

Naldrett A.J. 2004. Magmatic sulfide deposits: geology, geochemistry and exploration. Heildelberg, Springer, 727p. https://doi.org/10.1007/9783-662-08444-1

Naldrett A.J., Cabri L.J. 1976. Ultramafic and related mafic rocks; their classification and genesis with special reference to the concentration of nickel sulfides and platinum-group elements. Economic Geology, 71(7), 1131-1158. https://doi.org/10.2113/gsecongeo.71.7.1131

Naldrett A.J., Kinnaird L., Wilson A., Yudovskaya M., McQuade S., Chunnett G., Stanley C. 2009. Chromite composition and PGE 
content of Bushveld chromitites: part 1 - the lower and middle groups. Applied Earth Science: Transactions of the Institutions of Mining and Metallurgy: Section B, 118(3-4), 131-161. https://doi.org/10.1179/17432 7509X12550990458004

Naldrett A.J., Wilson A., Kinnaird J., Yudovskaya M., Chunnett G. 2012. The origin of chromitites and related PGE mineralization in the Bushveld Complex: new mineralogical and petrological constraints. Mineralium Deposita, 47, 209-232. https://doi.org/10.1007/s00126011-0366-3

Oliveira E.P., Souza Z.S., McNaughton N., Lafon J.M., Costa F.G., Figueiredo A.M. 2011. The Rio Capim volcanic-plutonic-sedimentary belt, São Francisco Craton, Brazil: geological, geochemical and isotopic evidence for oceanic arc accretion during Palaeoproterozoic continental collision. Gondwana Research, 19(3), 735-750. https:// doi.org/10.1016/j.gr.2010.06.005

Oliveira J.F., Cavalcante J.C. 1993. Mombaça: folha SB.24-V-D-V - estado do Ceará: texto explicativo. Escala 1:100.000. Brasília, DNPM/CPRM, 195p. Available on line at: https://rigeo.cprm.gov.br/ handle/doc/8664 / (accessed on 18 August 2021).

Pearce J.A. 1982. Trace element characteristics of lavas from destructive plate boundaries. In: Thorpe, R.S. (ed.). Orogenic andesites. Chichester, England, John Wiley and Sons, p.528-548. Available on line at: http://orca.cf.ac.uk/id/eprint/8625 / (accessed on 18 August 2021).

Pearce J.A. 2008. Geochemical fingerprinting of oceanic basalts with applications to ophiolite classification and the search for Archean oceanic crust. Lithos, 100(1-4), 14-48. https://doi.org/10.1016/j. lithos.2007.06.016

Pearce J.A., Peate D.W. 1995. Tectonic implications of the composition of volcanic arc magmas. Annual Review of Earth and Planetary Sciences, 23, 251-285. https://doi.org/10.1146/annurev. ea.23.050195.001343

Peccerillo A., Taylor S.R. 1976. Geochemistry of eocene calcalkaline volcanic rocks from the Kastamonu area, Northern Turkey. Contributions to Mineralogy and Petrology, 58, 63-81. https://doi. org/10.1007/BF00384745

Pessoa R.R., Archanjo C.J. 1984. Tectônica de empurrões na região de Tróia-CE. In: Congresso Brasileiro de Geologia, 33, 7211728. Available on line at: http://sbg.sitepessoal.com/anais digitalizados/1984-RIO\%20DE\%20JANEIRO/CBG.1984.vol.11.pdf / (accessed on 18 August 2021).

Pessoa R.R., Brito Neves B.B., Kawashita K., Pessoa D.R., Fuck R.A. 1986. Contribuição ao estudo da evolução geocronológica do Maciço de Tróia-CE. In: Simpósio de Geologia do Nordeste, 12, 75-93.

Pettigrew N.T., Hattori K.H. 2006. The Quetico intrusions of western superior province: Neo-Archean examples of Alaskan/Ural type mafic-ultramafic intrusions. Precambrian Research, 149(1-2), 21-42. https://doi.org/10.1016/j.precamres.2006.06.004

Prichard H.M., Economou-Eliopoulos M., Fisher P.C. 2008. Contrasting platinum-group mineral assemblages from two different podiform chromitite localities in the Pindos ophiolite complex, Greece. The Canadian Mineralogist, 46(2), 329-341. https://doi.org/10.3749/ canmin.46.2.329

Ripley E.M., Li C., Thakurta J. 2005. Magmatic Cu-Ni-PGE mineralization at a convergent plate boundary: preliminary mineralogic and isotopic studies of the Duke Island Complex, Alaska. In: Mao J., Bierlein F.P. (eds.). Mineral deposit research: meeting the global challenge. Berlin, Heidelberg, Springer. https://doi.org/10.1007/3-540-27946-6 13

Santos T.J.S., Amaral W.S., Ancelmi M.F., Pitarello M.Z., Fuck R.A., Dantas E.L. 2015. U-Pb age of the coesite-bearing eclogite from NW Borborema Province, NE Brazil: implications for western Gondwana assembly. Gondwana Research 28(3), 1183-1196. https://doi. org/10.1016/j.gr.2014.09.013

Sato K., Basei M. A. S., Siga Júnior O., Sproesser W. M., Passarelli C. R. 2008. Novas técnicas aplicadas ao método U-Pb no CPGeo - IGc/USP: avanços na digestão química, espectrometria de massa (TIMS) e exemplos de aplicação integrada com SHRIMP. Geologia USP. Série Científica, 8(2), 76-99. https://doi.org/10.5327/Z1519$\underline{874 X 2008000200006}$

Sato K., Tassinari C.C.G., Basei M.A.S., Siga Júnior O., Onoe A.T., Souza M.D. 2014. Microssonda lônica de Alta Resolução e de Alta Sensibilidade (SHRIMP Ile/MC) do Instituto de Geociências da Universidade de São Paulo, Brasil: método analítico e primeiros resultados. Geologia USP. Série Científica, 14(3), 3-18. https://doi. org/10.5327/Z1519-874X201400030001
Sattari P., Brenan J.M., Horn I., McDonough W.F. 2002. Experimental constraints on the sulfide- and chromite-silicate melt partitioning behavior of rhenium and platinum-group elements. Economic Geology, 97(2), 385-398. https://doi.org/10.2113/gsecongeo.97.2.385

Schulze D.J. 2001. Origins of chromian and aluminous spinel macrocrysts from kimberlites in Southern Africa. The Canadian Mineralogist, 39(2), 361-376. http://dx.doi.org/10.2113/gscanmin.39.2.361

Sereda E., Belyatsky B., Krivolutskaya N. 2020. Geochemistry and geochronology of Southern Norilsk intrusions, SW Siberian Traps. Minerals, 10(2), 165. https://doi.org/10.3390/min10020165

Silva L.C., Armstrong R., Pimentel M.M., Scandolara J., Ramgrab G., Wildner W., Angelim L.A.A., Vasconcelos A.M., Rizzoto G., Quadros M.L.E.S., Sander A., Rosa A.L.Z. 2002. Reavaliação da evolução geológica em terrenos pré-cambrianos brasileiros com base em novos dados U-PB Shrimp, parte III: províncias Borborema, Mantiqueira meridional e rio Negro-Juruena. Revista Brasileira de Geociências, 32(4), 529-544. https://doi.org/10.25249/0375-7536.2002324529544

Silva L.C., Costa F.G., Armstrong R., McNaugthon N.J. 2014. U-Pb (SHRIMP) zircon dating and $\mathrm{Nd}$ isotopes at basement inliers from northern Borborema Province, Ceará State, NE Brazil: evidences for the Archean and Paleoproterozoic crustal evolution. South American Symposium on Isotope Geology, 9. CD-ROM.

Simões S.J.C. 1993. Análise da Deformação Regional e Mineral do Complexo Pedra Branca (CE) e de Seus Depósitos Cromitíferos. MSc Dissertation, Universidade Estadual de Campinas, Instituto de Geociências, Campinas, 181 p. http://repositorio.unicamp.br/jspui/ handle/REPOSIP/287445

Spier C., Ferreira Filho C.F. 2001. The Chromite Deposits of the Bacuri Mafic-Ultramafic Layered Complex, Guyana Shield, Amapá State, Brazil. Economic Geology, 96(4), 817-835. https://doi.org/10.2113/ gsecongeo.96.4.817

Sousa H.P. 2016. Caracterização das unidades máfica-ultramáficas e potencial metalogenético da sequência metavulcanossedimentar Serra das Pipocas (Ceará): um provável Greenstone Belts. MSc Dissertation, Universidade Federal do Ceará, Fortaleza, 201p. http:// www.repositorio.ufc.br/handle/riufc/18796

Spandler C., Hermann J., Rubatto D. 2004. Exsolution of thortveitite, yttrialite, and xenotime during low-temperature recrystallization of zircon from New Caledonia, and their significance for trace element incorporation in zircon. American Mineralogist, 89, 1795-1806. https:// doi.org/10.2138/am-2004-11-1226

Srivastava R.K. 2008. Global intracratonic boninite-norite magmatism during the Neoarchaean-Paleoproterozoic: evidence from the central Indian Bastar craton. International Geology Review, 50(1), 61-74. https://doi.org/10.2747/0020-6814.50.1.61

Stacey J.S., Kramers J.D. 1975. Approximation of terrestrial lead isotope evolution by a 2-stage model. Earth and Planetary Science Letters, 26(2), 207-221. https://doi.org/10.1016/0012-821X(75)90088-6

Stowe C.W. 1994. Compositions and Tectonic Settings of Chromite Deposits through Time. Economic Geology, 89, 528-546. https://doi. org/10.2113/gsecongeo.90.7.2091

Su B.-X., Qin K.Z., Sakyi P.A., Malaviarachchi S.P.K., Liu P.P., Tang D.M., Xiao Q.H., Sun H., Ma Y.-G., Mao Q. 2012. Occurrence of an Alaskan-type complex in the Middle Tianshan Massif, Central Asian Orogenic Belt: inferences from petrological and mineralogical studies. International Geology Review, 54(3), 249-269. https://doi.org/10.1080 100206814.2010.543009

Sun S.S., Mcdonough W.F. 1989. Chemical and isotopic systematcs of oceanic basalts: implicatons for mantle compositon and processes. In: Saunders A.D., Norry M.J. (eds). Magmatism in the ocean basins. Geological Society, London, Special Publications, 42(1), 313. https:// doi.org/10.1144/GSL.SP.1989.042.01.19

Takahashi E., Uto K., Schilling J.G. 1987. Primary magma compositions and $\mathrm{Mg} / \mathrm{Fe}$ ratios of their mantle residues along Mid-Atlantic Ridge 29 $\mathrm{N}$ to $73 \mathrm{~N}$. Technical Reports, Institute for Study of the Earth's Interior Okayama University, Ser A. 9, p. 1-14.

Takazawa E., Okayasu T., Satoh K. 2003. Geochemistry and origin of the basal Iherzolites from the northern Oman ophiolite (northern Fizh block). Geochemistry, Geophysics, Geosystems, 4, 1021. https://doi. org/10.1029/2001GC000232

Tang G.J., Cawood P.A., Wyman D.A., Wang Q., Zhao Z.H. 2017. Evolving mantle sources in post-collisional early permian-triassic magmatic rocks in the heart of Tianshan Orogen (Western China). Geochemistry, Geophysics, Geosystems, 18(11), 4110-4122. https:// doi.org/10.1002/2017GC006977 
Taylor H.P.J. 1967. The zoned ultramafic complexes of southeastern Alaska. In: Wyllie P.J. (ed.). Ultramafic and related rocks. New York, Wiley, p. 97-121.

Tian W., Chen B., Ireland T. R., Green D. H., Suzuki K., Chu Z. 2011. Petrology and geochemistry of dunites, chromitites and mineral inclusions from the Gaositai Alaskan-type complex, North China Craton: implications for mantle source characteristics. Lithos, 127(12), 165-175. https://doi.org/10.1016/j.lithos.2011.08.013

Tolstykh N., Sidorov E., Kozlov, A. 2009. Platinum-group minerals from the Olkhovaya-1 placers related to the Karaginsky ophiolite complex, Kamchatskiy mys peninsula, Russia. The Canadian Mineralogist, 47(5), 1057-1074. https://doi.org/10.3749/canmin.47.5.1057

Trompette R. 1994. Geology of western gondwana, Pan-AfricanBrasiliano aggregation of South America. A.A. Balkema, Rotterdam, Brookfield, 350 p. https://doi.org/10.1201/9781003077664

Tseng C.Y., Zuo G.C., Yang H.J., Yang H.Y., Tung K.A., Liu D.Y., Wu H.Q. 2015. Occurrence of Alaskan-type mafic-ultramafic intrusions in the North Qilian Mountains, northwest China: evidence of Cambrian arc magmatism on the Qilian Block. Island Arc, 18(3), 526-249. https://doi. org/10.1111/j.1440-1738.2009.00675.x

Vanderhaeghe O., Ledru P., Thiéblemont D., Egal E., Cocherie A., Tegyey M., Milési J.P. 1998. Contrasting mechanism of crustal growth: geodynamic evolution of the Paleoproterozoic granite-greenstone belts of French Guiana. Precambrian Research, 92(2), 165-193. https://doi.org/10.1016/S0301-9268(98)00074-6

Vauchez A., Neves S.P., Caby R., Corsini M.E.S., Arthaud M.H., Amaro V. 1995. The Borborema shear zone system, NE Brazil. Journal of South American Earth Sciences, 8, 247-266. https://doi.org/10.1016/08959811(95)00012-5

Vishal, A.V.S., Handique. T., Ishwar-Kumar, C., 2020. Chromite chemistry as an indicator of petrogenesis and tectonic setting: the good and bad. Goldschmidt abstracts. https://doi.org/10.46427/gold2020.2688

von Blanckenburg F., Davies J.H. 1995. Slab breakoff: a model for syncollisional magmatism and tectonics in the Alps. Tectonics, 14(1), 120-131. https://doi.org/10.1029/94TC02051

Wager L.R., Brown G.M. 1967. Layered igneous rocks. San Francisco, Freeman and Co., $588 \mathrm{p}$.
Webb K. 2014. The Age and Tectonometallogenic Setting of the Fifield "Alaskan-Type" Intrusive Suite, Lachlan Orogen, NSW. Honour Thesis, University of Wollongong, 173 p. https://ro.uow.edu.au/thsci/79/

Williams I. 1998. U-Th-Pb geochronology by ion microprobe. In: McKibben, M.A., Shanks, W.C., Ridley, W.I. (eds.). Applications of microanalytical techniques to understanding mineralizing processes. Society of Economic Geologists, p.1-35. https://doi.org/10.5382/ Rev.07.01

Wilson M. 1989. Igneous petrogenesis: a global tectonic approach. Dordrecht, Springer, p. 466. https://doi.org/10.1007/978-1-40206788-4

Xu W., Zhao Z., Dai L. 2020. Post-collisional mafic magmatism: record of lithospheric mantle evolution in continental orogenic belt. Science China Earth Sciences, 63, 2029-2041. https://doi.org/10.1007/s11430019-9611-9

Yellappa T. 2021. High Ti- bearing Gabbros from Chalk Hills of Salem, Southern India: a co-genetic origin during Neoproterozoic Alaskantype evolution. Journal Geological Society of India, 97, 21-34. https:// doi.org/10.1007/s12594-021-1622-5

Yellappa T., Santosh M., Manju S. 2019. The mafic-ultramafic complex of Salem, southern India: an analogue for Neoproterozoic Alaskantype complex. Geological Journal, 54(5), 3017-3040. https://doi. org/10.1002/gj.3460

Yuan L., Zhang X., Yang Z., Lu Y., Chen H. 2017. Paleoproterozoic Alaskan-type ultramafic-mafic intrusions in the Zhongtiao mountain region, North China Craton: petrogenesis and tectonic implications. Precambrian Research, 296, 39-61. https://doi.org/10.1016/j. precamres.2017.04.037

Zaccarini F., Pushkarev E.V., Fershtater G.B., Garuti G. 2004. Composition and mineralogy of PGE-rich chromitites in the Nurali Iherzolite-gabbro complex, Southern Urals, Russia. The Canadian Mineralogist, 42(2), 545-562. https://doi.org/10.2113/gscanmin.42.2.545

Zhao Z.-F., Zheng Y.-F., Wei C.-S., Wu Y.-B., Chen F., Jahn B.M. 2005. Zircon $\mathrm{U}-\mathrm{Pb}$ age, element and $\mathrm{C}-\mathrm{O}$ isotope geochemistry of post-collisional mafic-ultramafic rocks from the Dabie orogen in east-central China. Lithos, 83(1-2), 1-28. https://doi.org/10.1016/j lithos.2004.12.014 